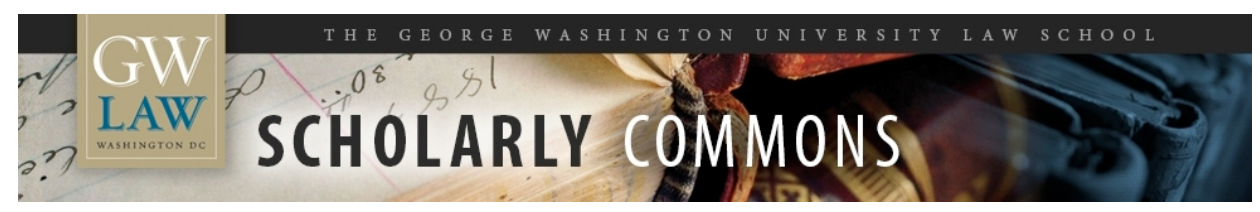

2004

\title{
The Constitutionality of International Delegations
}

\author{
Edward T. Swaine \\ George Washington University Law School, eswaine@law.gwu.edu
}

Follow this and additional works at: https://scholarship.law.gwu.edu/faculty_publications

Part of the Law Commons

\section{Recommended Citation}

Columbia Law Review, Vol. 104, p. 1492, 2004

This Article is brought to you for free and open access by the Faculty Scholarship at Scholarly Commons. It has been accepted for inclusion in GW Law Faculty Publications \& Other Works by an authorized administrator of Scholarly Commons. For more information, please contact spagel@law.gwu.edu. 


\section{COLUMBIA LAW REVIEW

\begin{tabular}{lll}
\hline VOL. 104 & OCTOBER 2004 & NO. 6
\end{tabular} \\ CONTENTS}

IN MEMORIAM—MALCOLM STEIN

Louis Lowenstein 1427

\section{ARTICLES}

EMBEDDED OPTIONS AND THE CASE AGAINST COMPENSATION IN CONTRACT LAW

Robert E. Scott 1428

George G. Triantis

THE CONSTITUTIONALITY OF INTERNATIONAL DELEGATIONS

Edward T. Swaine 1492

\section{NOTES}

The NBA LuXury TAX MODEL: A MisGuided

REGULATORY REGIME

1615

“The RePORTS OF My DeAth ARE GREATly

EXAGGERATED”: ADMINISTERING SECTION 5 OF THE

VOTING RIGHTS ACT AFTER GEORGIA V. ASHCROFT

1651

\section{ESSAYS}

OUR STRUCTURAL CONSTITUTION

Is SECTION 5 OF THE Voting Rights Act

A VICTIM OF ITS OWN SUCCESS?

How Not TO COUNT Votes
J. Harvie Wilkinson III 1687

Samuel Issacharoff 1710

John Copeland Nagle 1732 
RICHARD A. KAPLAN

Editor-in-Chief

SAIRA MOHAMED

Executive Articles

Editor

AMER S. AHMED

JUSTIN DAVIDS

JOSHUA SCHWARTZ

MONICA R. SHAH

BEN TRACHTENBERG

ZACHARY TRIPP

Articles Editors

SONESH CHAINANI

Alumni Liaison \& Senior Editor

JONATHAN GIFFORD

Symposium Chair

ANDREW AHERN

ZAINAB AHMAD

JUSTIN E. FAIRFAX

ROSS FIELDSTON

MICHAEL KOHLER

Senior Editors

SUE-YUN AHN

DANIEL BACKENROTH

STEPHEN L. BERO

CAMILLE CALMAN

ELLA CAMPI

DEREK CARE

KATHLEEN R. CRONIN-FURMAN

NATHAN MINH DAU

BEN DICKSON

BLAINE H. EVANSON

IGOR FUKS

SUHRID S. GAJENDRAGADKAR

QIAN A. GAO

ROSANNA M. GARZA

KATHLEEN CHOJNICKI

Business Manager

PETER BusCeMi

PETER CANELlos

LOUIS LOWENSTEIN

DAVID J. S. ZIFF

Executive Managing Editor

SHANNON RYAN

Technology Editor

RICHARD S. SCOTT

DAVID K. SPILLER

ANTON A. WARE

CAITH KUSHNER

MICHAEL MYERS

MICHAEL PAISNER

Senior Editors

GUILLERMO CACERES

Project Coordinator

GERARD LYNCH

NORY MILLER Executive Essay \& Review Editor

\author{
MATTHEW A. DOMBROSKI \\ BRITA M. SIEPKER \\ EMMA C. PRETE \\ JULIA WILLDORF \\ Managing Editors \\ NICHOLAS L. MCQUAID \\ CYNTHIA C. MENDEZ \\ Essay \& Review Editors
}

Bluebook Revision Editors

Staff
NAZMIYE ANNA GÖKÇEBAY
BENJAMIN M. GREENBLUM
ADRIENNE A. HARRIS
SVERKER K. HÖGBERG
WILLIAM J. KATT, JR.
KATHLEEN E. KAUFMANN
TODD KEITHLEY
OMAR KHAN
ANNE LAINER
YOUNG K. LEE
ALAN R. LEWIS
NATHAN LIPSCOMB
JASMINE S. MCGHEE
MONIQUE M. MENDEZ

Assistant Business Manager

Directors of the Columbia Law Review Association, Inc.
INÉS DUBBELS

MEghann E. DonahuE

Writing \& Research Editor

LISA ELLS

AMALIA JORNS

JASAND MOCK

JENS DAVID OHLIN

Notes Editors

MAURA DUNDON Guest Essay Editor

MATTHEW A. WINTERS Treasurer \& Senior Editor

JISUN LEE

Librarian

JOSEPH J. PONTRELLO

Y. RUPA RAO

MEGHAN H. SULLIVAN DEVIN E. VAN EXEL

NICHOLLE WINTERS Senior Editors

ALISON MONAHAN GRAHAM O'DONOGHUE AARON PAGE

ANTHONY RICKEY

CHRIS ROWAN

ARIE M. RUBENSTEIN EVAN RUDALL

AARON M. SACKS

ADAM P. SCHLEIFER

MICHAEL L. SHENKMAN

HEATHER TAKAHASHI

DEREK J. TANG

KEVIN WHELAN

RACHEL A. WILSON

WILLIAM SAVITT

DAVID M. SCHIZER

LEWIS S. YELIN 


\title{
THE CONSTITUTIONALITY OF INTERNATIONAL DELEGATIONS
}

\author{
Edward T. Swaine*
}

Do assignments of legislative power to international institutions like the World Trade Organization and the UN Security Council infringe the U.S. Constitution? Recent scholarship takes two radically different views. One perspective contends that such delegations are constitutionally problematic, chiefly in terms of the nondelegation doctrine and federalism. But a second perspective suggests that these doctrines lack legal or normative salience. Delegations of legislative authority, for some, are functionally indistinguishable from any other kind of legislation; federalism, others argue, offers no advantages over managed decentralization. On either ground, the incongruity between the increasing use of international delegations and U.S. constitutional principles is resolved by dismissing constitutional considerations altogether.

This Article favors neither perspective, and advances a new one. Some delegations of legislative authority do raise colorable constitutional issues. But the reasons why delegation analysis remains conceptually relevant-including the difficulty that any one nation has in controlling international institutions-indicate that such delegations actually serve other constitutional values, particularly the value federalism places on diffusing authority and creating checks on the power of the national government. That is, notwithstanding the adverse effects international institutions may have on the existing agents of U.S. federalism-the states-such delegations actually serve some of the same ends.

After explaining this claim, and addressing other welfarist and democratic concerns, the Article closes by identifying types of international delegations that remain particularly problematic. The objective is to avoid any overbroad indictment of international delegations, without at the same time denying the continuing salience of constitutional values.

* Associate Professor of Legal Studies, The Wharton School, and Associate Professor of Law, University of Pennsylvania Law School. I received valuable comments from participants in workshops hosted by the Wharton School, the University of Pennsylvania Law School, and the American Society of International Law's Interest Group on International Law in Domestic Courts. I thank the Legal Studies Department for a generous research grant. 
INTRODUCTION ..................................... 1494

I. The Nature of International Delegations . . . . . . . . . . 1502

A. Delegations of Treaty-Amending Authority......... 1506

B. Delegations of Authority to Legislate ............. . 1515

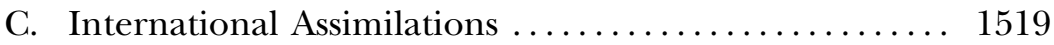

D. Customary International Law . . . . . . . . . . . . . 1522

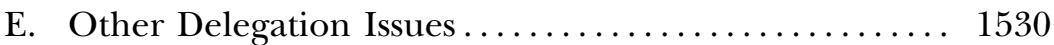

II. International Delegations and the Nondelegation

CANON .................................. 1536

A. The Apparent Relevance of the Nondelegation

Doctrine ............................... 1536

B. Nondelegation as an Underenforced Norm ........ . . 1544

1. The Practice of Underenforcement............ 1544

2. Disinterring the Nondelegation Doctrine ....... 1549

C. The Continuing Salience of the Nondelegation

Doctrine ................................. 1554

1. The Welfarist Case for Nondelegation. ........ 1556

2. The Democratic Case for Nondelegation ........ 1563

D. Balancing Nondelegation ..................... 1566

III. International Delegations and Constitutional

Federalism ................................. 1568

A. The Apparent Relevance of Federalism ............. . 1568

1. The Aggregate Effect of International Delegations ......................... 1569

2. State Priority over International Delegations .... . 1572

3. International Delegations as an Affront to State Sovereignty ...................... 1574

B. Federalism as an Underenforced Norm . . . . . . . . . . . 1577

C. The Continuing Salience of Federalism ........... 1580

IV. The Constitutional Case for International

Delegations................................... 1585

A. International Delegations and Diffusion .......... 1586

1. International Delegations as a Constraint on U.S. Authority ......................... 1586

2. International Delegations and Relative Gains to Diffusion ......................... 1593

3. International Delegations and the Other Virtues of Federalism ............................. 1597

4. The Tension Between Federalism and Nondelegation ........................ 1601

B. Qualifications ................................ 1604

1. Monopolizing Delegations ................ 1605

2. Reverse Delegations .................... 1609

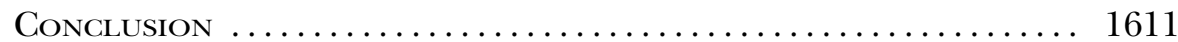


The fundamental precept of the delegation doctrine is that the lawmaking function belongs to Congress and may not be conveyed to another branch or entity.

-Justice Kennedy, in Loving v. United States (1996) ${ }^{1}$

The answer to Lord Ellenborough's famous rhetorical question, "Can the Island of Tobago pass a law to bind the rights of the whole world?" may well be yes, where the world has conferred such binding authority through treaty.

-Justice Breyer, in Torres v. Mullin (2003) ${ }^{2}$

\section{INTRODUCTION}

The practice of delegating to international institutions-vesting them with the authority to develop binding rules ${ }^{3}$ - sometimes looks like

1. 517 U.S. 748, 758 (1996) (internal citation omitted).

2. 124 S. Ct. 562, 565 (2003) (Breyer, J., dissenting from denial of cert.) (quoting Buchanan v. Rucker, 103 Eng. Rep. 546, 547 (K.B. 1808) (Ellenborough, C.J.)).

3. Terminology is critical in defining this Article's scope. First, the delegating acts in question are domestic statutes or international agreements that vest continuing lawmaking authority in an international institution, not those that compromise national authority simply by virtue of the original agreement. See Curtis A. Bradley, International Delegations, the Structural Constitution, and Non-Self-Execution, 55 Stan. L. Rev. 1557, 1558 n.2 (2003) [hereinafter Bradley, International Delegations] (making similar distinction); see also Ernest A. Young, The Trouble with Global Constitutionalism, 38 Tex. Int'l L.J. 527, 537 (2003) [hereinafter Young, Trouble] (noting that the WTO and NAFTA "constitute institutions rather than simply establish binding commitments").

Second, the authority so vested must be capable of some kind of legal effect on the international or domestic plane: something more than mere pronouncements or hortatory acts, but not necessarily having direct effect in domestic law. Contrast George A. Bermann, Constitutional Implications of U.S. Participation in Regional Integration, 46 Am. J. Comp. L. 463, 463 (Supp. 1998) (differentiating "agreements that create new institutions and ostensibly vest those institutions with the power to make 'law' that will be binding and directly effective within the states that are party to them" from conventional international agreements).

Third, I follow political scientists in defining "international institutions" quite broadly-including not only international organizations, but also international legal regimes that lack such a concrete identity. See Robert O. Keohane, International Institutions: Can Interdependence Work?, Foreign Pol'y, Spring 1998, at 82, 82 (describing international institutions as "rules that govern elements of world politics and the organizations that help implement those rules"); see also Stephen D. Krasner, Structural Causes and Regime Consequences: Regimes as Intervening Variables, in International Regimes 2 (Stephen D. Krasner ed., 1982) (defining international regimes as "sets of implicit or explicit principles, norms, rules, and decision-making procedures around which actors' expectations converge in a given area of international relations"). This incorporates numerous arrangements that allocate corporate authority to a conference of the parties (COP), or a meeting of the parties (MOP), rather than to any traditional intergovernmental organization. See Robin R. Churchill \& Geir Ulfstein, Autonomous Institutional Arrangements in Multilateral Environmental Agreements: A Little-Noticed Phenomenon in International Law, 94 Am. J. Int'l L. 623, 623 (2000) (describing prevalence of such arrangements in environmental treaties); id. at 626 (differentiating COPs and MOPs from traditional intergovernmental organizations). More 
the next New Deal. Despite its continuing mistrust of international engagements, ${ }^{4}$ the United States continues to vest new authority in established organizations, such as the United Nations (UN), the Organisation for Economic Co-operation and Development (OECD), and the International Labour Organization (ILO), and to create new institutions, like the World Trade Organization (WTO) and the North American Free Trade Agreement (NAFTA), that exercise considerable power over U.S. affairs. The march seems inexorable. Notwithstanding painfully slow progress in the Doha Round of WTO negotiations, and a tenuous commitment to the sacrifices required by free trade, the United States is trying to extend NAFTA-like institutions across the rest of the Americas. ${ }^{5}$ And after undertaking a military campaign in Iraq marked for its unilateral character, the United States ceded substantial authority over reconstruction efforts

controversially, it includes aspects of customary international law. See infra notes 111-134 and accompanying text.

Fourth, and finally, I focus on delegations of legislative, rather than judicial or executive, power. This makes a difference in domestic constitutional terms, and also reflects a category generally recognized within the law of international organizations. See infra notes 29-44 and accompanying text. In surveying international delegations, however, I do take note of several that are predominately executive or judicial in character. See infra notes 145-156 and accompanying text.

4. One observer summarized:

From the law of the seas to the Kyoto Protocol, from the biodiversity convention, from the extraterritorial application of the trade embargo against Cuba or Iran, from the brusk calls for reform of the World Bank and the International Monetary Fund and the International Criminal Court: American unilateralism appears as an omnipresent syndrome pervading world politics.

Joseph S. Nye, Jr., The Paradox of American Power 155 (2002) (quoting Harald Muller). For assessments of U.S. unilateralism and its causes, see Multilateralism and U.S. Foreign Policy: Ambivalent Engagement (Stewart Patrick \& Shepard Forman eds., 2002); U.S. Hegemony and International Organizations: The United States and Multilateral Institutions (Rosemary Foot et al. eds., 2003). For a history of the U.S. position in the twentieth century, see Edward C. Luck, Mixed Messages: American Politics and International Organization, 1919-1999 (1999).

5. See Elizabeth Becker, For Bush, A Janus-Like View of Trade, N.Y. Times, Nov. 12, 2003, at C1. The draft Free Trade Area of the Americas (FTAA) agreement contains robust, NAFTA-like dispute resolution provisions, see FTAA-Free Trade Area of the Americas, Third Draft Agreement, Nov. 21, 2003, ch. XXIII, FTAA Doc. FTAA.TNC/w/ 133/Rev.3, available at http://www.ftaa-alca.org/FTAADraft03/Index_e.asp (on file with the Columbia Law Review), even if its scope may have become less ambitious than was once the case, see Paul Blustein, Trade Talks End in Vague Accord, Wash. Post, Nov. 21, 2003, at E1-and though it should also be noted that other recent trade agreements are more modest in this regard, see, e.g., United States-Central America Free Trade Agreement, June 1, 2004, art. 20, available at http://www.ustr.gov/assets/Trade_Agreements/ Bilateral/DR-CAFTA/DR-CAFTA_Final_Texts/asset_upload_file85_3940.pdf (on file with the Columbia Law Review). Beyond the Americas, the Doha Round appears to have been jump-started by recent agricultural commitments. WTO General Council, Doha Work Programme: Decision Adopted by the General Council on 1 August 2004, WT/L/579 (Aug. 2, 2004), available at http://www.wto.org/english/tratop_e/dda_e/ddadraft_31jul 04_e.pdf (on file with the Columbia Law Review). 
to new entities governed by existing international agencies, ${ }^{6}$ made concessions to Iraqi sovereignty in order to secure passage of a UN Security Council resolution, ${ }^{7}$ and tried to secure military assistance from NATO. ${ }^{8}$

Just as with the New Deal, which in effecting an analogous reassignment of domestic political authority weathered serious constitutional objections to the delegation of legislative power, ${ }^{9}$ opinions about the new international arrangements-their significance and their merits-are sharply divided. Sometimes they are described as entrusting U.S. regulatory authority to a sinister cabal of foreign potentates, ${ }^{10}$ inviting caricature. ${ }^{11}$ Nevertheless, serious concerns may be perceived. International delegations, critics suggest, inappropriately compromise the authority of national and local governments, invite rent seeking, reduce global wel-

6. The International Reconstruction Trust Fund Facility for Iraq, for example, was developed by the UN Development Group and the World Bank, United Nations-World Bank International Reconstruction Trust Fund Facility for Iraq, at http://www.uniraq.org/ donors/irffi.asp\#Documents_and_Guidelines (last visited Aug. 29, 2004) (on file with the Columbia Law Review), and the International Advisory and Monitoring Board for Iraq, established pursuant to a UN Security Council Resolution, includes representatives of offices within the UN, the International Monetary Fund (IMF), the Arab Fund for Economic and Social Development, and the International Bank for Reconstruction and Development (IBRD). International Advisory and Monitoring Board for Iraq, Terms of Reference (Oct. 24, 2003), at http://www.iamb.info/tor.htm (on file with the Columbia Law Review); see S.C. Res. 1483, U.N. SCOR, 58th Sess., 4761st mtg., U.N. Doc. S/RES/ 1483 (2003) (outlining multilateral approach to rebuilding Iraq); Steven R. Weisman, U.S. to Cede Part of Control over Aid to Iraq, N.Y. Times, Oct. 20, 2003, at A1 (discussing U.S. plans to transfer control of Iraqi aid to agency controlled by UN and World Bank).

7. Robin Wright \& Dana Milbank, U.S. Bends to France, Russia on U.N. Iraq Resolution, Wash. Post, June 8, 2004, at A4; see S.C. Res. 1546, U.N. SCOR, 59th Sess., 4987th mtg., U.N. Doc. S/Res/1546 (2004).

8. Jackie Calmes, Chirac Reaffirms No Wider Role for NATO in Iraq, Wall St. J., June 10, 2004, at A2. For further discussion, see infra text accompanying notes 402-412.

9. See 2 Bruce Ackerman, We the People: Transformations 255-61, 295-303 (1998) (describing transformation of administrative state in 1930s against nondelegation challenges); David Schoenbrod, Power Without Responsibility 37-40, 158-64 (1993) (describing similar developments, but denying that constitutional transformation).

10. See, e.g., Patrick J. Buchanan, The Great Betrayal 264-65 (1998) (voicing sovereignty concerns about NAFTA); id. at 313 ("Run by nameless, faceless, foreign bureaucrats, the WTO is the embryonic trade ministry of a world government."); Cliff Kincaid, Global Bondage: The U.N. Plan to Rule the World 97 (1995) (criticizing UN as a nascent world government, representing "a transfer of powers delegated to the people by the Constitution to more distant levels of government, this time on an international level"); Marc A. Thiessen, When Worlds Collide: Out with the New, Foreign Pol'y, Mar.-Apr. 2001, at 64, 64 (characterizing "a plethora of new regional and global supranational institutions" as effecting "[a] transformation . . . of a magnitude unseen since the Protestant Reformation and the creation of the modern nation-state almost 500 years ago").

11. See, e.g., Jose E. Alvarez, The New Treaty Makers, 25 B.C. Int'l \& Comp. L. Rev. 213, 215 (2002) [hereinafter Alvarez, Treaty Makers] ("For believers in threatening U.N. black helicopters, the erosion of sovereignty implies lack of control or undemocratic delegations of power to faceless international bureaucrats."). 
fare, diminish accountability in governance, and undermine democracy. ${ }^{12}$ In a recent, widely noted essay, ${ }^{13}$ Jed Rubenfeld commented that:

The antidemocratic qualities of the United Nations, the International Monetary Fund (IMF), and other international governance organizations-their centralization, their opacity, their remoteness from popular or representative politics, their elitism, their unaccountability-are well known. . . . World government in the absence of world democracy is necessarily technocratic, bureaucratic, diplomatic-everything but democratic.

...

... What sets [America's] teeth on edge [are] . . . binding agreements administered, interpreted, and enforced by multilateral bodies ... . America's commitment to democratic self-government gives the United States good reason to be skeptical about-indeed, to resist-international legal regimes structured . . around antinationalist and antidemocratic principles. ${ }^{14}$

These objections have found a constitutional footing. Recent legal scholarship has identified inconsistencies between international delegations and the constitutional bar on delegating legislative authority. ${ }^{15}$ Other

12. See, e.g., Eyal Benvenisti, Exit and Voice in the Age of Globalization, 98 Mich. L. Rev. 167, 170-84 (1999) [hereinafter Benvenisti, Exit and Voice] (describing capture of international institutions by small interest groups); Eric Stein, International Integration and Democracy: No Love at First Sight, 95 Am. J. Int'l L. 489, 490 (2001) (noting claim in academic discourse that "internationalization 'almost invariably means a loss of democracy'" (quoting Ralf Dahrendorf, The Third Way and Liberty: An Authoritarian Streak in Europe's New Center, Foreign Aff., Sept./Oct. 1999, at 13, 16)); Paul B. Stephan, Accountability and International Lawmaking: Rules, Rents and Legitimacy, 17 Nw. J. Int'l L. \& Bus. 681, 698-99 (1996-1997) (describing international lawmaking's relative lack of accountability and vulnerability to interest group politics); Roland Vaubel, A Public Choice View of International Organizations, in The Political Economy of International Organizations: A Public Choice Approach 27, 27-40 (Roland Vaubel \& Thomas D. Willett eds., 1991) (citing problems of rent seeking and lack of effective oversight); cf. Kal Raustiala, Rethinking the Sovereignty Debate in International Economic Law, 6 J. Int'l Econ. L. 841, 841 n.1 (2003) [hereinafter Raustiala, Rethinking] (citing examples of "voluminous" literature on international institutions, sovereignty, and democratic accountability).

13. Compare, e.g., George F. Will, Paris Versus Philadelphia, Newsweek, Oct. 13, 2003, at 80, 80 (describing Rubenfeld's essay as "mind-opening"), with Anne-Marie Slaughter, A Dangerous Myth, Prospect, Jan. 22, 2004, at 11, 11 (criticizing Rubenfeld's essay as resting on flawed constitutional analysis and a view of international law "unrecognisable to an international lawyer").

14. Jed Rubenfeld, The Two World Orders, Wilson Q., Autumn 2003, at 22, 34, 36.

15. See, e.g., Bradley, International Delegations, supra note 3, passim (describing delegation concerns, and advocating non-self-execution of treaty obligations as remedy); Lori Fisler Damrosch, "Sovereignty" and International Organizations, 3 U.C. Davis J. Int'l L. \& Pol'y 159, 159-61, 165-66 (1997) [hereinafter Damrosch, Sovereignty] (describing tensions between delegations to international organizations and the nondelegation doctrine); Julian G. Ku, The Delegation of Federal Power to International Organizations: New Problems with Old Solutions, 85 Minn. L. Rev. 71, 77-78 (2000) (advocating resuscitation of nondelegation doctrine for foreign affairs); John C. Yoo, The New Sovereignty and the Old Constitution: The Chemical Weapons Convention and the 
scholarship takes the view that constitutional federalism is at stake, insofar as exercises of delegated authority sometimes challenge attributes of state sovereignty. ${ }^{16}$ Enforcing the nondelegation doctrine, then, would

Appointments Clause, 15 Const. Comment. 87, 111, 114-16 (1998) [hereinafter Yoo, New Sovereignty] (describing nondelegation issues adjacent to Appointment Clause objections to international delegations); Young, Trouble, supra note 3, at 533-38 (noting challenges posed by supranational lawmaking to constitutional scheme); see also David A. Koplow, When Is an Amendment Not an Amendment?: Modification of Arms Control Agreements Without the Senate, 59 U. Chi. L. Rev. 981, 1042-43 (1992) (concluding that, as a result of deferential standard of judicial review, delegated authority in arms control agreements "would probably be upheld as constitutional-but only barely").

Many others, it should be stressed, see nothing unduly problematic about international delegations. See, e.g., Louis Henkin, Foreign Affairs and the United States Constitution 247-73 (2d ed. 1996) [hereinafter Henkin, Foreign Affairs] (finding few constitutional issues to be posed by international delegations); David Golove, The New Confederalism: Treaty Delegations of Legislative, Executive, and Judicial Authority, 55 Stan. L. Rev. 1697, 1699-1701 (2003) (expressing skepticism regarding normative and doctrinal case against international delegations); Neil Kinkopf, Of Devolution, Privatization, and Globalization: Separation of Powers Limits on Congressional Authority to Assign Federal Power to Non-Federal Actors, 50 Rutgers L. Rev. 331, 358-65, 382-85, 392-96 (1998) (concluding that international delegations would be problematic under existing Supreme Court dictum, but should be upheld under general separation of powers principles); Chantal Thomas, Constitutional Change and International Government, 52 Hastings L.J. 1, 11-15, 40-46 (2000) (contending that international delegations are transformational, "generat[ing] a de facto 'international branch' of federal government"); Mark Tushnet, Transnational/Domestic Constitutional Law, 37 Loy. L.A. L. Rev. 239, 251-57 (2003) [hereinafter Tushnet, Transnational/Domestic] (suggesting that criticisms of international delegations are exaggerated and reflect general discomfort with role of courts); Note, Discretion and Legitimacy in International Regulation, 107 Harv. L. Rev. 1099, 1107-08 (1994) ("dismiss[ing] quickly" on doctrinal and policy grounds the possibility of "interpret[ing] the nondelegation doctrine to bar Congress from delegating authority to make international law").

16. See, e.g., Jeremy Rabkin, Why Sovereignty Matters 68-69 (1998) (describing impact of global governance on federalism); Enid F. Beaumont, Domestic Consequences of Internationalization, in Globalization and Decentralization 374, 374-86 (Jong S. Jun \& Deil S. Wright eds., 1996) (describing effect of globalization and international trade agreements on federalism); Bermann, supra note 3, at 466-67 (noting that "NAFTA effectively mandates coordinated and even uniform rules on certain matters previously left to independent state regulation and seeks to ensure that all state laws and regulations in areas such as health, safety and environmental protection conform to the standards established through the NAFTA framework"); Bradley, International Delegations, supra note 3, at 1559 ("[D] elegations of authority to international institutions . . . have the potential to erode U.S. federalism by enhancing the power of the entire federal government vis-à-vis the states."); Ku, supra note 15, at 72-73 (drawing on federalism doctrine to evaluate propriety of international delegations); Young, Trouble, supra note 3, at 532-41 (describing tensions between international assignments of authority and federalism); Julie Long, Note, Ratcheting Up Federalism: A Supremacy Clause Analysis of NAFTA and the Uruguay Round Agreements, 80 Minn. L. Rev. 231, 232-33 (1995) ("U.S. accession to NAFTA and the Uruguay Round Agreements challenges traditional state powers in the name of free international trade in a way that never before has been accomplished."). 
seemingly vindicate two constitutional norms at one fell swoop, in addition to remedying bedrock political concerns-such as the promotion of democratic governance-that have less immediate constitutional salience.

One problem with this solution is that the constitutional doctrines of nondelegation and federalism are themselves of limited salience. Each exemplifies what Lawrence Sager memorably dubbed "underenforced constitutional norms": not abandoned, exactly, but hardly enforced to their "full conceptual limits." 17 The nondelegation doctrine is rarely decisive, ${ }^{18}$ even less so in foreign affairs, ${ }^{19}$ and it has been called "moribund" for so long that one might assume (mistakenly) that it has already shuf-

Other commentators, of course, suggest that concerns about state sovereignty are misplaced. See, e.g., Michael S. Greve, Real Federalism: Why It Matters, How It Could Happen 2 (1999) [hereinafter Greve, Real Federalism] (commenting that "[a]gainst the backdrop of an intense debate over the (perceived or real) loss of American sovereignty to ... international organizations, ... the dignities and powers of the states seems secondary, if not wholly anachronistic," but distinguishing legitimate concerns about "real federalism"); A.J. Tangeman, Comment, NAFTA and the Changing Role of State Government in a Global Economy: Will the NAFTA Federal-State Consultation Process Preserve State Sovereignty?, 20 Seattle U. L. Rev. 243, 243-46 (1996) (describing concerns regarding state sovereignty and federalism, but concluding that federal-state consultation process under NAFTA provides model for reconciliation).

17. Lawrence Gene Sager, Fair Measure: The Legal Status of Underenforced Constitutional Norms, 91 Harv. L. Rev. 1212, 1221 (1978) [hereinafter Sager, Fair Measure]. Subsequent scholarship has explained how such norms may be influential in statutory construction. See, e.g., Hiroshi Motomura, Immigration Law After a Century of Plenary Power: Phantom Constitutional Norms and Statutory Interpretation, 100 Yale L.J. 545, 547-48 (1990) (explaining how plenary power doctrine has resulted in courts neglecting constitutional claims and deciding cases instead on the basis of "subconstitutional" concerns); Ernest A. Young, Constitutional Avoidance, Resistance Norms, and the Preservation of Judicial Review, 78 Tex. L. Rev. 1549, 1581-85 (2000) [hereinafter Young, Constitutional Avoidance] (describing how avoidance doctrine can result in overenforcement of constitutional provisions).

18. The leading-which is to say, only-cases applying the doctrine to strike down congressional statutes are Panama Refining Co. v. Ryan, 293 U.S. 388 (1935), and A.L.A. Schechter Poultry Corp. v. United States, 295 U.S. 495 (1935). That said, the doctrine continues to be invoked, and seriously considered, to this day. See, e.g., Whitman v. Am. Trucking Ass'ns, 531 U.S. 457, 463 (2001) (discussing lower court's suggestion that narrower construction of statute at issue could cure unconstitutional delegation of legislative power); see also infra text accompanying notes 204-218 (discussing Supreme Court's nondelegation doctrine jurisprudence).

19. United States v. Curtiss-Wright Exp. Corp., 299 U.S. 304, 320 (1936) (asserting that in order to avoid embarrassment and promote national objectives, "congressional legislation which is to be made effective through negotiation and inquiry within the international field must often accord to the President a degree of discretion and freedom from statutory restriction which would not be admissible were domestic affairs alone involved"); see Henkin, Foreign Affairs, supra note 15, at 124-25 (concluding that nondelegation doctrine has "never had much" life in foreign affairs, but noting increasing attempts by Congress to limit delegations and possibility that delegation remained constitutionally circumscribed when delegated power "impinges on individual rights"). 
fled off. ${ }^{20}$ And while federalism crops up in an impressive array of constitutional decisions, the principle that states have an inviolable sovereignty over certain subject matters has also fallen out of fashion, ${ }^{21}$ and was never robust in foreign affairs. ${ }^{22}$ There is a gap, in short, between the theoretical import of the nondelegation and federalism doctrines and their actual practice.

As if that were not enough, some would address this apparent incongruity not by reviving those doctrines, but rather by denying that either one had any conceptual integrity in the first place. Delegating authority, it is argued, is legally and functionally identical to ordinary legislating, and should hardly be singled out for constitutional scrutiny. ${ }^{23}$ Federalism, too, is said to offer no advantage (and considerable disadvantage) as against elective, nationally managed decentralization. ${ }^{24}$ Taken together, these criticisms suggest that the Constitution has nothing relevant to say about international delegations: Not only are the nondelegation and federalism doctrines rarely enforced by the judiciary, but they utterly fail to advance any discernible constitutional value.

20. E.g., Nat'l Cable Television Ass'n, Inc. v. United States, 415 U.S. 336, 353 (1974) (Marshall, J., dissenting) (describing doctrine as "virtually abandoned" and "moribund"); Synar v. United States, 626 F. Supp. 1374, 1384 (D.D.C. 1986) (explaining that, "while the delegation doctrine may be moribund, it has not yet been officially interred by the Court"), aff'd sub nom. Bowsher v. Synar, 478 U.S. 714 (1986). For metaphoric variety, see Gary Lawson, Delegation and Original Meaning, 88 Va. L. Rev. 327, 330 (2002) ("The nondelegation doctrine, however, is the Energizer Bunny of constitutional law: No matter how many times it gets broken, beaten, or buried, it just keeps on going and going."); Antonin Scalia, A Note on the Benzene Case, Regulation, July/Aug. 1980, at 25, 28 ("[E]ven with all its Frankenstein-like warts, knobs, and (concededly) dangers, the unconstitutional delegation doctrine is worth hewing from the ice."). Both Professor Lawson and, in time, Justice Scalia, nonetheless conceded that the doctrine was essentially dormant. See Mistretta v. United States, 488 U.S. 361, 416 (1989) (Scalia, J., dissenting) (noting that the Supreme Court has "almost never felt qualified to second-guess Congress" regarding the permissibility of delegations, and that it last did so "over half a century ago"); Lawson, supra, at 334 ("[T] he forces that ground down the nondelegation doctrine are still at work, and they are not likely to go away.").

21. See infra text accompanying notes 363-369.

22. See infra text accompanying notes 371-373.

23. See Eric A. Posner \& Adrian Vermeule, Interring the Nondelegation Doctrine, 69 U. Chi. L. Rev. 1721, 1757-59 (2002) [hereinafter Posner \& Vermeule, Interring].

24. See Edward L. Rubin, The Fundamentality and Irrelevance of Federalism, 13 Ga. St. U. L. Rev. 1009, 1013, 1026-28 (1997) (arguing that interest in federalism is artificially generated by virtues more properly attributed to decentralization, which may in fact be impaired by a federal structure); Edward L. Rubin \& Malcolm Feeley, Federalism: Some Notes on a National Neurosis, 41 UCLA L. Rev. 903, 910-26 (1994) (distinguishing federalism from decentralization and arguing that decentralization, not federalism, serves needs of safeguarding citizen participation, fostering competition, and facilitating experimentation); see also Frank B. Cross, The Folly of Federalism, 24 Cardozo L. Rev. 1, 19-51 (2002) (elaborating theoretical and practical tensions between decentralization and federalism); Edward L. Rubin, Puppy Federalism and the Blessings of America, 574 Annals Am. Acad. Pol. \& Soc. Sci. 37, 39-40 (2001) (explaining why distinguishing between federalism and decentralization is necessary for coherent discourse). 
So which view ought to prevail-that international delegations offend the Constitution, or that the underlying doctrines invoked are misconceived and functionally irrelevant? Neither, in my reckoning. While the judiciary may be ill equipped to strike down international delegations on constitutional grounds, the conceptual relevance of nondelegation and federalism to international delegations is not so easily dismissed. International delegations are demonstrably different from domestic delegations of legislative authority-primarily because the United States is just one of many principals directing its international agents. And for this reason, among others, the role of international delegations in reassigning authority from the states is more problematic than when that authority is assumed (and retained) by the national government.

It does not follow, however, that international delegations are an affront to the Constitution. Such measures are constitutional in two important and reinforcing senses. International delegations are troubling precisely because they are constitutional in character: That is, legislative authority conferred on international institutions is difficult to reclaim. ${ }^{25}$ By the same token, however, this kind of commitment indirectly promotes a more specific constitutional value: the diffusion of political authority prized by federalism. While delegating national power to international institutions redistributes national legislative authority (including that which might otherwise fall to the states), it provides a bulwark against the concentration of political power in the national government that is consistent with the ambitions of federalism.

Viewed this way, international delegations are constitutional in an important-and neglected-regard: They advance a constitutional value that deserves to be measured against any harm to constitutional values that they may risk. This does not, of course, amount to a concrete finding that international delegations should always withstand constitutional scrutiny, even in terms of the nondelegation and federalism doctrines. It does, however, warrant resisting a preemptive, undifferentiated constitutional objection to such activities, particularly any that would condemn them outright. It is also a small step toward a more sophisticated analysis, one particularly relevant to Congress and the President, for distinguishing types of delegations that are most problematic.

This argument consists of four parts. Part I begins by describing some existing U.S. arrangements with international institutions that look like legislative delegations. Part II considers the continuing salience of

25. Cf. Samuel Issacharoff, The Enabling Role of Democratic Constitutionalism: Fixed Rules and Some Implications for Contested Presidential Elections, 81 Tex. L. Rev. 1985, 1996-99 (2003) (emphasizing significance of permanence as a constitutional quality). To be clear, this notion of constitutionalism does not require privileging economic liberalism or, for that matter, incorporating noneconomic values in WTO principles. Contrast Robert Howse \& Kalypso Nicolaidis, Enhancing WTO Legitimacy: Constitutionalization or Global Subsidiarity?, 16 Governance 73, 76-83 (2003) (critically assessing rival understandings of WTO constitutionalism). 
nondelegation concerns, defending the notion that international delegations should be considered as presenting an issue distinct from ordinary legislation-without concluding that they are unconstitutional. Part III then considers the continued salience of federalism, which superficially looks like a reason to dislike international delegations (and which plays that role in national discourse about international engagements), but which in fact provides a strong warrant in their favor. Part IV assesses how we might reconcile some of the competing impulses of federalism and nondelegation, including by identifying two species of international delegation that are particularly problematic - the aggregation of power in multipurpose international institutions, which is potentially troubling in federalism terms, and "reverse" delegations reverting to national institutions, which may be particularly pernicious examples of delegation offenses.

\section{The Nature of International Delegations}

The significance and variety of international delegations are impressive, and it is necessary to survey those delegations in order to ground the analysis. But this overview is limited in several important respects. Because the objective is to explore the relationship between these delegations and U.S. constitutional doctrine, I discuss only those international institutions in which the United States participates or has seriously considered participating, rather than the entire universe of international instruments. ${ }^{26}$ Even within that class, commentators have identified a number of respects in which U.S. transfers of power to international institutions raise delegation concerns. I focus here on the broadest, and arguably the most problematic, category-assignments of what might be deemed "legislative" power-though I briefly identify and contrast other kinds of international delegations at the end of this Part. ${ }^{27}$

26. This necessarily excludes international delegations of the first significance, such as the European Union. The U.S. focus also misses how other nations struggle to reconcile international delegations with domestic nondelegation principles and the constitutional role of subnational governments. See, e.g., Richard Deeg, Contemporary Challenges to German Federalism: From the European Union to the Global Economy, 33 Law \& Pol'y Int'l Bus. 51 (2001); Uwe Kischel, Delegation of Legislative Power to Agencies: A Comparative Analysis of United States and German Law, 46 Admin. L. Rev. 213 (1994); see also infra note 173 (noting practice in the Netherlands and Denmark).

27. Two other limits are temporal in character. First, I do not assess whether contemporary delegations are revolutionary in character, and I likewise assume that prior practice has not conclusively resolved their constitutionality. While some commentators consider international delegations to have changed in character during the twentieth century, see, e.g., Ku, supra note 15, at 79-88 (describing nature of "new" international law and its domestic encroachments); Thomas, supra note 15, passim (indicating case for constitutional transformation), others argue that international delegations were anticipated prior to the Constitution and regarded as appropriate immediately afterwards. See Golove, supra note 15, at 1744-46 (concluding that two early treaties demonstrate that 
Concerns about legislative delegations derive from Article I of the U.S. Constitution, which assigns "[a]ll legislative Powers herein granted" to the Congress. ${ }^{28}$ The constitutional understanding of "legislative Powers" does not, of course, bear any necessary relation to the types of authority exercised by international institutions. Even if international lawyers might agree with the Supreme Court that legislating involves "the determination of the legislative policy and its formulation and promulgation as a defined and binding rule of conduct," 29 that abstraction has little correspondence to the way authority is described in international agreements, let alone how that authority should be regarded for constitutional purposes.

The ILO illustrates the potential for, and weaknesses of, the analogy to domestic legislation. ILO officials have sometimes described the organization as a world legislature, ${ }^{30}$ but its primary function is to promulgate conventions that nations may later choose whether to adopt. ${ }^{31}$ Activities of this character, which are common among international organizations, seem more like introducing bills than enacting legisla-

President Washington and the first Senate "understood the treaty power to provide them with broad authority and that ... domestic nondelegation doctrines and the Appointments Clause were inapplicable in the treaty context”); cf. Field v. Clark, 143 U.S. 649, 683, 690-91 (1892) (attaching great weight to practice of Congress in conferring trade and commerce powers on the President). Second, I concentrate on existing, rather than potential, international delegations. Many of the same issues arise, however, in evaluating proposed U.S. engagements. See, e.g., Bradley, International Delegations, supra note 3, at 1578 n.99 (discussing Optional Protocol to the Convention Against Torture and Other Cruel, Inhuman and Degrading Treatment or Punishment, opened for signature Feb. 4, 2003, 42 I.L.M. 26). I consider possible implications for future delegations in Part IV.

28. U.S. Const. art. I, $\S 1$; see id. art. I, $\$ 8$ (detailing powers).

29. Yakus v. United States, 321 U.S. 414, 424 (1944); see, e.g., Edward Yemin, Legislative Powers in the United Nations and Specialized Agencies 6 (1969) ("[L] egislative acts have three essential characteristics: they are unilateral in form, they create or modify some element of a legal norm, and the legal norm in question is general in nature, that is, directed to indeterminate addressees and capable of repeated application in time."). Assessments of the prevalence of international legislation vary markedly, perhaps due to the lack of any shared understanding of the term. Cf. infra notes 42-44 and accompanying text (noting salience, to some, of nonunanimity). Compare, e.g., Paul C. Szasz, The Security Council Starts Legislating, 96 Am. J. Int'l L. 901, 901 (2002) (noting that "[i]t has long been accepted that intergovernmental organizations (IGOs) cannot legislate international law," but noting exceptions), with Gunter Handl, Environmental Security and Global Change: The Challenge of International Law, in Environmental Protection and International Law 59, 62 (Winfried Lang et al. eds., 1991) (describing "the prospect of a virtually continuous legislative enterprise" created by existing international institutions).

30. See, e.g., Florence Ellinwood Allen, The Treaty as an Instrument of Legislation 77 (1952) (quoting ILO Director-General's proclamation that " $[\mathrm{t}]$ oday the role of the organization as to an international parliament has become generally accepted”).

31. The ILO also issues recommendations, which are by their nature nonbinding. Constitution of the International Labor Organization, Instrument of Amendment, adopted Oct. 9, 1946, art. 19, 62 Stat. 3485, 3518-32, 15 U.N.T.S. 35, 68-80 [hereinafter ILO Constitution] (describing procedure governing conventions and recommendations). 
tion $^{32}$ - nor, for that matter, do they suggest that such organizations are acting as "the new treaty makers." 33

At the same time, the analogy to domestic legislation does not capture all of the ILO's lawmaking potential. For example, the ILO Constitution may be amended. ${ }^{34}$ Moreover, even if everyone can agree that promulgating conventions is not, by itself, legislating, ${ }^{35}$ the ILO compels all of its members-not just those voting for a convention's adoption-to submit it to the national authorities responsible for ratification. ${ }^{36}$ This is an obligation to submit, not an obligation to ratify, ${ }^{37}$ but the difference between the two obligations is not as substantial as may be imagined. ${ }^{38}$ The ILO has also asserted that members have a constitutional obligation to respect certain conventions regardless of whether they have ratified

32. Bowett's Law of International Institutions 277 (Philippe Sands \& Pierre Klein eds., 5th ed. 2001) (noting that an international organizations does not “'legislate[ ]' for its member states"; rather, its member states "take part in the process of adopting a convention within the framework of an organisation . . - - retaining a complete freedom of choice on the question of whether to become a party to that instrument later on"); Julia Sommer, Environmental Law-making by International Organisations, 56 Zeitschrift für ausländisches öffentliches Recht und Völkerrecht [ZaörV] 628, 638 (1996) (explaining that promulgation of multilateral conventions is "not real law-making by an international organisation but rather the preparation of inter-state lawmaking within an international organisation").

33. Alvarez, Treaty Makers, supra note 11, at 213.

34. ILO Constitution, supra note 31, art. 36, 62 Stat. at 3550, 15 U.N.T.S. at 100 (providing that amendments adopted by a two-thirds majority of the ILO General Conference take effect when ratified or accepted by two-thirds of the members, "including five of the ten Members . . . represented on the Governing Body as Members of chief industrial importance"); see infra note 45 (discussing UN procedure for amending Charter).

35. This has been the focus of lengthy debate. See, e.g., Hector Bartolomei de la Cruz et al., The International Labor Organization: The International Standards System and Basic Human Rights 21-24 (1996) (describing "long and interesting debate"); Virginia A. Leary, International Labour Conventions and National Law 11-12 (1982) (reporting debate). But the question would seem to have been authoritatively resolved. See Competence of the International Labour Organization to Regulate, Incidentally, the Personal Work of the Employer, 1926 P.C.I.J. (ser. B) No. 13, at 17 (July 23) ("The [ILO] has no legislative power. Each member is free to adopt or reject any proposals of the Organization either for a national law or for an international convention.”).

36. ILO Constitution, supra note 31, art. 19(5), 62 Stat. at 3520, 15 U.N.T.S. at 70.

37. Bowett's Law of International Institutions, supra note 32, at 278.

38. Id. at 277-79 (noting differences between ILO and conventional treaty practices); cf. Claire Moore Dickerson, Transnational Codes of Conduct Through Dialogue: Leveling the Playing Field for Developing-Country Workers, 53 Fla. L. Rev. 611, 656-57 (2001) (“As a practical matter . . . even ratified conventions can be optional. While the ILO has an intricate, formal enforcement process ultimately leading to the International Court of Justice, the implementation of ratified ILO conventions in fact occurs because of an elaborate system of publicity and shaming."). 
them. ${ }^{39}$ While the legal authority for such a declaration is unclear, ${ }^{40}$ the result resembles what the United States opposed on nondelegation grounds in the original draft charter. ${ }^{41}$

As this example suggests, international legislation may take forms unfamiliar to domestic constitutional analysis, and it is tempting to winnow out some of the variations. The clearest basis might involve state consent. Traditionally, nations enjoyed the right to maintain an international insti-

39. See ILO Declaration on Fundamental Principles and Rights at Work, art. 2, June 18, 1998, 37 I.L.M. 1233, 1237 (1998) (declaring that "all Members," even those that have not ratified the relevant Conventions, "have an obligation arising from the very fact of membership in the Organization, to respect, to promote and to realize, in good faith and in accordance with the Constitution, the principles concerning the fundamental rights which are the subject of those Conventions," such as those guaranteeing nondiscrimination and freedom of association). See generally Brian A. Langille, The ILO and the New Economy: Recent Developments, 15 Int'l J. Comp. Lab. L. \& Indus. Rel. 229, 229-30 (1999) (stating that member states "have constitutional obligations simply by virtue of ILO membership").

40. See Clyde Summers, NAFTA's Labor Side Agreement and International Labor Standards, 3 J. Small \& Emerging Bus. L. 173, 184 (1999) ("It is uncertain whether this Declaration can make specific conventions binding on [nations] by virtue of their ILO membership, so as to become a part of their internal law ...."). A U.S. participant stressed that the Declaration did not establish any legal obligation "beyond the present text of the ILO Constitution." Report of the Committee on the Declaration of Principles: Submission, Discussion and Adoption (Discussion in Plenary), International Labour Conference, 86th Sess. (1998), available at http://www.ilo.org/public/english/standards/ relm/ilc/ilc86/com-decd.htm (on file with the Columbia Law Review) (statement of E. Potter); accord Report of the Committee on the Declaration of Principles: Committee Report, International Labour Conference, 86th Sess. (1998), available at http:// www.ilo.org/public/english/standards/relm/ilc/ilc86/com-decl.htm (on file with the Columbia Law Review) (citing assertions by member state representatives that Declaration does not impose any legal obligations on member states). One might, consistent with this view, regard the Declaration as more interpretive in character. But interpretation is nominally assigned to the International Court of Justice, see ILO Constitution, supra note 31 , art. $37(1), 62$ Stat. at 3550,15 U.N.T.S. at $92-$ or to another tribunal that has not yet been created, id. art. 37(2), 62 Stat. at 3550-52, 15 U.N.T.S. at 100-and the authority of any other body is dubious, see de la Cruz et al., supra note 35, at 35-36. But cf. W. Paul Gormley, Human Rights and Environment: The Need for International Cooperation 46 (1976) ("ILO Common Law . . is binding on ILO members, without the requirement of ratification. Legal obligations are assumed by the acceptance (or the continuation) of ILO membership."); Allyn L. Taylor, Globalization and Biotechnology: UNESCO and an International Strategy to Advance Human Rights and Public Health, 25 Am. J.L. \& Med. 479, 529 (1999) ("[A]ll international instruments, whether declaratory or binding in form, imply an obligation on state parties to cooperate in good faith in the realization of the rights and obligations involved.").

41. See Pitman B. Potter, Inhibitions on the Treaty-Making Power of the United States, 28 Am. J. Int'l L. 456, 456 (1934) (reporting submission of U.S. delegates that " $[t]$ o permit a foreign body to conclude a treaty binding upon the United States would be equivalent to delegating the [Senate's] power of making treaties in the measure of the provisions of the treaty in question"). 
tution's status quo, such as by requiring unanimous assent for proposing changes, by imposing consensus rules that respected the rights of objecting states, or, where the adoption by a majority was permitted, by reserving to each state the right to refuse ratification. ${ }^{42}$ This quasi-contractual approach has been relaxed in some institutions-where, for example, amendments may be adopted and made fully effective by a majority (including after initial attempts to secure a consensus), states refusing to ratify changes may be suspended or find that the original, unamended treaty expires, and amendments may automatically come into force for each state absent its timely dissent-and some consider only such departures from unanimity to be international legislation. ${ }^{43}$

Such a rigid definition is underinclusive, in my view, because it too readily assumes that the existence of a veto ameliorates any delegation problems. ${ }^{44}$ Nonetheless, departures from unanimity are certainly the most compelling examples of international legislative delegations, and this Part will focus on them. For ease of exposition, these examples are separated into several general categories: (1) delegations of treatyamending authority; (2) delegations of more standard legislative authority; (3) assimilations; and (4) customary international law.

\section{A. Delegations of Treaty-Amending Authority}

A number of institutions permit treaty amendment without the assent of the United States. ${ }^{45}$ Some provide that member nations may change basic treaty terms-in essence, the constitutional architecture of

42. See Henry G. Schermers \& Niels M. Blokker, International Institutional Law $\$ \S 781-790$ (4th ed. 2003) (describing traditional commitment to unanimity in international organizations, the advent of majority voting, and the resurgence of mechanisms more closely resembling unanimity rules); see also id. $\$ \S 771-780$ (describing decisionmaking by consensus, including variants that allowed ultimate recourse to majority voting).

43. See Krzysztof Skubiszewski, International Legislation, in 2 Encyclopedia of Public International Law 1255, 1255-58 (Rudolph Bernhardt ed., 1995) (noting scholarly views on defining international legislation and categorizing types of legislative procedures); cf. Bowett's Law of International Institutions, supra note 32, at 263-75 (describing decline of unanimity and development of alternative schemes); Raustiala, Rethinking, supra note 12, at 847-48 (exploring significance of veto for conceptions of sovereignty).

44. See infra notes 176-183 and accompanying text. As noted immediately below, any more rigid approach is also contingent, insofar as institutions in which some nations have a privileged role (like the Security Council, with its veto for Permanent Members) would nonetheless be considered legislative in character for other, less powerful nations. See infra note 45 .

45. Others permit treaty amendment without the assent of every party, but not without the assent of privileged members like the United States-creating a delegation issue that is more acute for other member nations. The $\mathrm{UN}$ is a case in point. Amendments to the Charter come into force only after approval by two-thirds of the General Assembly and ratification by two-thirds of the members, "including all the 
an international arrangement. ${ }^{46}$ The WTO is an important, if unrealized, illustration. In addition to permitting change through new rounds of multilateral negotiations, the WTO may by a supermajority of its members decide to amend its basic agreement or other provisions. ${ }^{47}$ That option has in fact never been exploited; ${ }^{48}$ any changes affecting a member's rights and obligations, moreover, generally require its acquies-

permanent members of the Security Council." U.N. Charter art. 108 (emphasis added); see also id. art. 109, para. 2 (providing identical requirements for approval of amendments recommended by a General Conference of members). Unsurprisingly, the Charter has rarely been amended. See generally Carolyn L. Willson, Changing the Charter: The United Nations Prepares for the Twenty-First Century, 90 Am. J. Int'l L. 115 (1996) (summarizing history of amendments). But cf. infra text accompanying notes 52-64 (noting prospect of de facto amendment via interpretation).

The ILO, on the other hand, demonstrates that a privileged position is not necessarily permanent, and that privileges may be less than decisive. Amendments to the ILO Constitution may be adopted by a two-thirds majority, but only if that majority includes five of the ten "Members of chief industrial importance." ILO Constitution, supra note 31, art. 36, 62 Stat. at 3550, 15 U.N.T.S. at 100. The United States is one such member, see Composition of the Governing Body of the International Labour Office (as elected on 10th June 2002 and modified to 30 November 2003), GB.05 (2002-2005) (Rev.3), available at http://www.ilo.org/public/english/standards/relm/gb/refs/pdf/gbmember.pdf (on file with the Columbia Law Review), but its status is subject to change by the Governing Body. ILO Constitution, supra note 31, art. 7(3), 62 Stat. at 3502, 15 U.N.T.S. at 52. Moreover, it would have to secure the support of at least four other members of chief industrial importance in order to defeat a two-thirds majority.

46. Schermers \& Blokker, supra note 42, § 1173 ("Many constitutions require ratification by a qualified majority of the members before a decision for amendment can enter into force. The decision will then bind all members.”); id. \$§ 1173-1175 (citing examples and exploring implications); see also id. \$§ 1178-1186 (citing examples in which international organizations may amend or supplement their constitutions by decision or interpretation)

47. Marrakesh Agreement Establishing the World Trade Organization, Apr. 15, 1994, art. X, § 1, Uruguay Round of Multilateral Trade Negotiations: Legal Instruments Embodying the Results of the Uruguay Round of Multilateral Trade Negotiations Done at Marrakesh on 15 April 1994, vol. 1, at 137, 142 (1994), 33 I.L.M. 1144, 1149 (1994) [hereinafter WTO Agreement]. Some provisions may be amended only with the consent of all members. Id. art. X, § 2 .

48. Daniel K. Tarullo, The Hidden Costs of International Dispute Settlement: WTO Review of Domestic Anti-Dumping Decisions, 34 Law \& Pol'y Int'l Bus. 109, 172 (2002) (concluding that "the WTO 'legislators' must agree unanimously to new rules," since "[i]n practice, amendments to the WTO (and the GATT before it) are just not made, whether through consensus or voting"). This point was emphasized during U.S. consideration of the Uruguay Round. The Uruguay Round Agreements Act: Statement of Administrative Action, attached to H.R. Rep. No. 103-826, pt. 1, at 656 (1994), reprinted in 1994 U.S.C.C.A.N. 4040, 4045-46. There have been attempts, however, most notably a proposed amendment to the Dispute Settlement Understanding submitted to the Third Session of the Ministerial Conference in 1999, but that proposal was not acted upon. Council for Trade-Related Aspects of Intellectual Property Rights, Proposals on Paragraph 6 of the Doha Declaration on the TRIPS Agreement and Public Health: Thematic Compilation, IP/C/W/363/Add.1, II 20(1), at 5 (July 23, 2002), available at http:/ /docsonline.wto.org/ DDFDocuments/t/IP/C/W363A1.doc (on file with the Columbia Law Review). 
cence. ${ }^{49}$ But other institutions, like the IMF $^{50}$ and the International Criminal Court (ICC), ${ }^{51}$ permit amendment of their governing instruments without such safeguards. The result, in theory, is that the United States has assented to some institutions (and considered assenting to others) that could alter its obligations without its consent.

49. Certain amendments affecting the rights and obligations of members take effect "for the Members that have accepted them upon acceptance by two thirds of the Members and thereafter for each other Member upon acceptance by it." WTO Agreement art. X, $\$ 3$. This is less than a right to veto. The WTO Ministerial Conference may by a threefourths vote decide that a duly adopted amendment is of sufficient import that any member must accept it within a specified period or feel "free to withdraw from the WTO or to remain a Member with the consent of the Ministerial Conference." Id. In addition, amendments to the trade provisions not involving members' rights and obligations take effect for all members upon the acceptance by two-thirds. Id. art. X, $\S 4$. To be sure, amendments not adopted by consensus fall by default within the category of those altering rights and obligations - that is, requiring acceptance by individual members in order to be effective against them-but a contrary conclusion may be reached by a three-fourths vote. Id. art. X, § 1 . In sum, changes to the trade provisions may be imposed by a supermajority's will, even should a particular member take the view that the changes affect its rights and obligations. Amendments to the General Agreement on Trade in Services (GATS) follow somewhat similar principles; amendments to certain provisions are binding on all members once a two-thirds majority is secured, and even for amendments requiring acceptance by members, the Ministerial Conference may present nonconsenting members with the choice of withdrawing or remaining only by its leave. Id. art. X, $\S 5$.

50. Proposals to amend the Articles of Agreement must first be approved by the Board of Governors, which decides by a majority of (weighted) votes. Articles of Agreement of the International Monetary Fund, Dec. 27, 1945, art. XXVIII, 60 Stat. 1401, 2 U.N.T.S. 39, amended by 20 U.S.T. 2775; 29 U.S.T. 2203; T.I.A.S. No. 11898, available at http://www.imf.org/external/pubs/ft/aa/index.htm (on file with the Columbia Law Review). The amendment may then be approved by "three-fifths of the members, having eighty-five percent of the total voting power." Id. art. XXVIII(a); see, e.g., John W. Head, Suspension of Debtor Countries' Voting Rights in the IMF: An Assessment of the Third Amendment to the IMF Charter, 33 Va. J. Int'l L. 591, 630-42 (1993) (discussing adoption of an amendment permitting the suspension of voting rights of a member country that persistently fails to abide by the Agreement). The IMF also has the power to alter quotas for members, which in turn affects voting rights. See Articles of Agreement of the International Monetary Fund, supra, art. III(2) (assigning authority over altering quotas and subscriptions to Board of Governors); id. art. XV(2) (describing method by which Fund is to determine valuation of the special drawing right); id. art. XII (detailing operation of Board of Governors, and voting procedures).

51. The Rome Statute provides that parties may by a two-thirds vote define the elements of international crimes. Rome Statute of the International Criminal Court, July 17, 1998, art. 9, 2187 U.N.T.S. 90, 98 [hereinafter Rome Statute]; see Report of the Preparatory Commission for the International Criminal Court, Addendum, Part II, Finalized Draft Text of the Elements of Crimes, U.N. Doc. PCNICC/2000/1/Add.2 (2000) (defining terms relating to genocide, crimes against humanity, and war crimes). It also provides for the amendment of other terms by a supermajority, Rome Statute, supra, arts. 121(3), 123(3), but specifies that parties objecting to certain amendments may limit their legal effect, id. art. 121(5), and further permits parties to withdraw from the treaty more easily in the teeth of objectionable amendments, id. art. 121(6). 
Equivalent changes may be more subtly accomplished through an institution's interpretation of its own charter. ${ }^{52}$ The WTO, for example, has the authority to adopt binding interpretations of its governing agreement by a supermajority vote ${ }^{53}$ (though this authority, like the power to amend the WTO agreements, is more apparent than real $\left.{ }^{54}\right)$. In the context of particular disputes, moreover, the WTO's Dispute Settlement Body (DSB) also has the ability to issue binding interpretations ${ }^{55}$-with the potential to circumvent limits on the WTO's more formal legislative

52. When the UN was founded, a committee reported that General Assembly competence to interpret the Charter was "inherent in the functioning of any body which operates under an instrument defining its functions and powers." Lori F. Damrosch et al., International Law: Cases and Materials 147 (4th ed. 2001) (quoting report). See generally C.F. Amerasinghe, Principles of the Institutional Law of International Organizations 24-61 (1996) (describing role played by international organizations in interpreting their constitutions); Schermers \& Blokker, supra note 42, §§ 1155-1156 (same).

The comprehensive, and potentially recursive, character of interpretive authority is best illustrated by the UN Security Council, which has effectively interpreted the Charter so as to diminish the efficacy of Permanent Members' vetoes. Article 27(3) indicates that any substantive measure requires their "concurring votes," but Council practice treats it as sufficient if no negative vote is cast-that is, interpreting "concurring votes" to include abstentions. Willson, supra note 45, at 118. The Council also established a subsidiary entity, composed of Council members, in order to oversee Gulf War claims against Iraqand specified that the veto would not apply therein. S.C. Res. 692, U.N. SCOR, 46th Sess., 2987th mtg., U.N. Doc. S/RES/692 (1991) (incorporating by reference Report of the Secretary-General Pursuant to Paragraph 19 of Security Council Resolution 687 (1991), U.N. SCOR, 47th Sess., 2981st mtg., at II 10, U.N. Doc. S/22559 (1991)). "The overall effect was to delegate a decision-otherwise subject to the veto-to a subsidiary organ (with the same membership as the Council) where the veto does not apply." David D. Caron, The Legitimacy of the Collective Authority of the Security Council, $87 \mathrm{Am}$. J. Int'l L. 552, 585 (1993).

53. WTO Agreement art. IX(2) (assigning to Ministerial Conference and General Council "the exclusive authority to adopt interpretations" of referenced agreements upon a three-fourths majority vote of the members, save where doing so "would undermine the [formal] amendment provisions").

54. Stein, supra note 12, at 500 n.62 (noting that interpretation provision "has remained a dead letter").

55. Understanding on Rules and Procedures Governing the Settlement of Disputes, Apr. 15, 1994, arts. 2(1), 3(2), WTO Agreement, Annex 2, Uruguay Round of Multilateral Trade Negotiations: Legal Instruments Embodying the Results of the Uruguay Round of Multilateral Trade Negotiations Done at Marrakesh on 15 April 1994, vol. 31, at 25,537, 25,539-41 (1994) [hereinafter DSU]. Under the DSU, the DSB, comprised of representatives from all WTO members, WTO Agreement art. IV(3), establishes panels to entertain disputes, see DSU arts. 2(1), 6-8, 11, and adopts decisions by those panels and by the Appellate Body. Id. arts. 16, 17(14). Notwithstanding the DSB's ultimate control, the arbitral panels and the Appellate Body retain the real interpretive authority: Their decisions become binding only when adopted by the DSB, but the DSB is deemed to have adopted them unless it musters a consensus to reject them. Id. arts. 16(4), 17(14). Since at least one WTO member usually benefits from the underlying decision, this requirement of unanimity effectively eliminates the DSB's supervisory capacity. See Oren Perez, Normative Creativity and Global Legal Pluralism: Reflections on the Democratic Critique of Transnational Law, 10 Ind. J. Global Legal Stud. 25, 38 \& n.47 (2003). 
capacity ${ }^{56}$ - and has already rendered several decisions adverse to the United States. ${ }^{57}$

The WTO instruments themselves suggest that this interpretive authority is unexceptionable, ${ }^{58}$ and it is difficult to distinguish categorically from garden-variety interpretation by the judiciary or by an executive agency 59 - save perhaps in terms of the latitude available to those interpreting, or the commitment to distinctive institutional tenets. ${ }^{60}$ But to many, the power of international institutions to interpret their founding instruments is a significant source of authority for generating new rules. ${ }^{61}$

56. Cf. R.E. Hudec, Free Trade, Sovereignty, Democracy: The Future of the World Trade Organization, 1 World Trade Rev. 211, 212-17, 222 (2002) (noting concern, but cautioning against its exaggeration).

57. See, e.g., United States-Import Prohibition of Certain Shrimp and Shrimp Products (Recourse to Article 21.5 of the DSU by Malaysia) (Report of the Appellate Body), WT/DS58/AB/RW (Oct. 22, 2001), 41 I.L.M. 149 (2002); United StatesStandards for Reformulated and Conventional Gasoline (Report of the Appellate Body), $\mathrm{WT} / \mathrm{DS} 2 / \mathrm{AB} / \mathrm{R}$ (May 20, 1996), 35 I.L.M. 603 (1996); infra notes 414-416 and accompanying text (discussing steel and FSC cases). The U.S. track record, however, is not distinctly poor. John Greenwald, WTO Dispute Settlement: An Exercise in Trade Law Legislation?, 6 J. Int'l Econ. L. 113, 114 \& n.4, 123 \& n.17 (2003).

58. See DSU art. 3(2) ("Recommendations and rulings of the DSB cannot add to or diminish rights and obligations provided in the covered agreements."). The Appellate Body has also announced its intention to resolve doubts against the assertion of obligations limiting state sovereignty (in dubio mitius). EC Measures Concerning Meat and Meat Products (Hormones) (Report of the Appellate Body), WT/DS26/AB/R, WT/DS48/AB/ R, II 165 (Jan. 16, 1998). U.S. law, it should also be noted, limits the domestic enforcement of WTO panel decisions. Uruguay Round Agreements Act, Pub. L. No. 103-465, $\S 102$ (b) (2) (A), (B) (i), 108 Stat. 4809, 4815 (1994) (codified as amended at 19 U.S.C. \$3512(b) (2) (A), (B) (i) (2000)) (providing that state laws may be declared inconsistent with Uruguay Round Agreements only in suits brought by United States, and that in such actions a WTO panel decision "shall not be regarded as binding or otherwise accorded deference").

59. See Jerome Frank, Words and Music: Some Remarks on Statutory Interpretation, 47 Colum. L. Rev. 1259, 1269 (1947) (describing statutory interpretation as "inescapably a kind of legislation"). Distinguishing between legislating, on the one hand, and interpreting (or executing), on the other, is obviously a central difficulty afflicting the nondelegation doctrine.

60. See, e.g., Greenwald, supra note 57, at 114 (noting WTO emphasis on free trade).

61. See, e.g., Jose E. Alvarez, Constitutional Interpretation in International Organizations, in The Legitimacy of International Organizations 104, 113, 137-38 (JeanMarc Coicaud \& Veijo Heiskanen eds., 2001) (describing how institutions' interpretations of vague charters can sometimes drastically change meaning of instruments notwithstanding significant opposition within membership, including so as to effect the "domestic jurisdiction" reserved under UN Charter for sovereign regulation); Laurence Boisson de Chazournes \& Sarah Heathcote, The Role of the New International Adjudicator, 95 Am. Soc'y Int'l L. Proc. 129, 133-34 (2001) (describing interpretation by dispute settlement bodies as "necessary judicial legislation" caused by failure of member states to create, clarify, and enforce international law). With respect to the WTO in particular, see Raj Bhala, The Myth About Stare Decisis and International Trade Law (Part One of a Trilogy), 14 Am. U. Int'l L. Rev. 845, 848-49 (1999) (“[T] he distinction between judges as bureaucrats/arbitrators, on the one hand, and as lawmakers/legislators, on the other hand, is crumbling at the WTO."); Greenwald, supra note 57, at 113 (characterizing 
Inspired in part by criticisms voiced elsewhere in the government, ${ }^{62}$ Congress has evidenced concern about the WTO in particular, with one senator claiming that its panels "have ceased interpreting our trade agreements and have begun legislating." ${ }^{3}$ This objection's force is strengthened, ironically, by the difficulty of formally overriding such interpretations. ${ }^{64}$

While formally amending and interpreting are the most prominent means for accomplishing basic architectural changes, a third, newly controversial route involves reservations to multilateral treaties. Nations are generally permitted under international law to ratify multilateral treaties subject to reservations, at least so long as the reservation is not barred by the treaty in question or inconsistent with its object and purpose. ${ }^{65}$ The Vienna Convention allows other nations to object, ${ }^{66}$ but it also allows

WTO dispute settlement proceedings as largely "an exercise in trade law legislation"); Joel P. Trachtman, The Domain of WTO Dispute Resolution, 40 Harv. Int'l L.J. 333, 336 (1999) ("[D]ispute resolution is not simply a mechanism for neutral application of legislated rules but is itself a mechanism of legislation and of governance."). For a recent argument that such concerns are overstated, see Richard H. Steinberg, Judicial Lawmaking at the WTO: Discursive, Constitutional, and Political Constraints, 98 Am. J. Int'l L. 247 (2004).

62. GAO, Report to the Ranking Minority Member, Committee on Finance, U.S. Senate: World Trade Organization: Standard of Review and Impact of Trade Remedy Rulings 27 (GAO Doc. No. GAO-03-824, 2003), available at http://www.gao.gov/cgi-bin/ getrpt?GAO-03-824 (on file with the Columbia Law Review) (reporting view of U.S. agencies that WTO decisions have applied standard of review precluding "permissible interpretations of WTO members' domestic agencies," and in some cases "found obligations and imposed restrictions . . . that are not supported by the texts of the WTO trade remedy agreements"); U.S. Secretary of Commerce, Executive Branch Strategy Regarding WTO Dispute Settlement Panels and the Appellate Body: Report to the Congress Transmitted by the Secretary of Commerce 7-10 (2002), available at http:// www.ita.doc.gov//FinalDec31ReportCorrected.pdf (on file with the Columbia Law Review) (criticizing certain findings for their "lack of grounding in the negotiated agreement texts and ... their failure to recognize that agreement terms may be susceptible of multiple, reasonable interpretations among which Members may properly choose"). The GAO noted, however, that many experts disagreed with the executive branch's assessment. GAO, supra, at 27, 31.

63. 149 Cong. Rec. S4173 (daily ed. Mar. 21, 2003) (statement of Sen. Baucus).

64. See supra notes 48-49, 54 and accompanying text (describing infrequent exploitation of amendment alternatives in the WTO); see also Donald McRae, What is the Future of WTO Dispute Settlement?, 7 J. Int'l Econ. L. 3, 13 (2004) ("Only in the rarest of circumstances will enough Members be in agreement that the consequences of an Appellate Body interpretation are so harmful that the decision must be reversed through amendment or authoritative interpretation.").

65. Vienna Convention on the Law of Treaties, opened for signature May 23, 1969, art. 19, 1155 U.N.T.S. 331, 336-37 [hereinafter VCLT]. The United States is not a party to the Vienna Convention but generally accepts it as indicating the customary international law of treaties. See Curtis A. Bradley \& Jack L. Goldsmith, Treaties, Human Rights, and Conditional Consent, 149 U. Pa. L. Rev. 399, 424 \& n.120 (2000) [hereinafter Bradley \& Goldsmith, Treaties].

66. VCLT, supra note 65 , arts. 20-23, 1155 U.N.T.S. at 337-38. 
international organizations themselves to decide the permissibility of reservations to their constituent treaties unless the treaties provide otherwise. ${ }^{67}$ The United States is also a party to other treaties, such as the International Covenant on Civil and Political Rights, in which a treaty organ has asserted (there, over the protest of the United States and other nations) the right to evaluate the acceptability of reservations. ${ }^{68}$ This authority is especially significant in light of contemporaneous assertions that the organ may treat invalid ratifications as severable, so that the reserving nation becomes a party to the treaty on different terms than it originally ratified. ${ }^{69}$

Finally, some treaties, often relating to the environment, permit more pedestrian amendments to be accomplished without the agreement of all parties. Such treaties typically allow a qualified majority to adopt amendments to the body of the treaty, while ensuring that those amendments are in force only for parties ratifying them. ${ }^{70}$ The ratification safeguard does not apply, however, to certain technical annexes; the resulting tacit acceptance procedure, in which amended annexes bind any party failing to object within a specified period, ${ }^{71}$ displays more of a notional

67. Id. art. 20(3), 1155 U.N.T.S. at 8.

68. ICCPR Human Rights Comm., General Comment 24(52) on Issues Relating to Reservations Made upon Ratification or Accession to the Covenant or Optional Protocols Thereto, or in Relation to Declarations Under Article 41 of the Covenant, 52d Sess., 1382d mtg., at 10, U.N. Doc. CCPR/C/21/Rev.1/Add.6 (1994). For the U.S. reaction, see Observations by the United States on General Comment 24, 3 Int'l Hum. Rts. Rep. 265, 265-69 (1996); for generally consistent support from other nations, see Observations by France on General Comment 24 on Reservations to the ICCPR, 4 Int'l Hum. Rts. Rep. 6, 6-8 (1997); Observations by the United Kingdom on General Comment 24, 3 Int'l Hum. Rts. Rep. 261, 261-65 (1996).

69. For rival views concerning the acceptability of this practice, compare Ryan Goodman, Human Rights Treaties, Invalid Reservations, and State Consent, 96 Am. J. Int'l L. 531 (2002) (noting severability practices and defending their consistency with state consent), with Bradley \& Goldsmith, Treaties, supra note 65, at 436-38 (criticizing severability).

70. For examples, see Churchill \& Ulfstein, supra note 3, at 636-39; Patrick Széll, Decision Making Under Multilateral Environmental Agreements, 26 Envtl. Pol'y \& L. 210 (1996).

71. E.g., Convention on the Prior Informed Consent Procedure for Certain Hazardous Chemicals and Pesticides in International Trade (PIC Convention), Sept. 11, 1998, arts. 21(3), 22(3)-(4), 38 I.L.M. 1, 14-15 (signed, but not yet ratified, by the United States); Convention on the Control of Transboundary Movements of Hazardous Wastes and Their Disposal (Basel Convention), concluded Mar. 22, 1989, art. 18, 1673 U.N.T.S. 57, 144-45 (signed, but not yet ratified, by the United States); Convention on International Trade in Endangered Species of Wild Fauna and Flora (CITES), Mar. 3, 1973, art. XV(2)(f), 27 U.S.T. 1087, 1111, 993 U.N.T.S. 243, 255; Convention on the Prevention of Marine Pollution by Dumping of Wastes and Other Matter, Dec. 29, 1972, art. XV(2), 26 U.S.T. 2403, 2413, 1046 U.N.T.S. 138, 144-45; International Convention for the Regulation of Whaling, Dec. 2, 1946, art. V(3), 62 Stat. 1716, 1717-18, 1718-19, 161 U.N.T.S. 72, 80, 82. This model is not confined to environmental agreements. E.g., Convention on the Marking of Plastic Explosives for the Purpose of Detection, Mar. 1, 1991, art. VII, S. Treaty Doc. No. 103-8, 30 I.L.M. 721, 728-29; International Convention 
respect for sovereign consent. ${ }^{72}$ Other agreements stray still further from any consensus rule. The Montreal Protocol's provisions for "adjusting" technical annexes permit a supermajority to adopt changes that are subject neither to ratification nor to objection by an individual party. ${ }^{73}$ Similarly, the Additional Protocol between the United States and the International Atomic Energy Agency (IAEA) provides that a majority of the IAEA Board of Governors may (after consultation with experts) amend the activities, equipment, and material covered, and that any such amendments take effect four months after adoption-without need for U.S. ratification. ${ }^{74}$

These relaxed procedures for tacit acceptance are premised on the ground that the amendments are administrative and technical, rather than political, in character. ${ }^{75}$ They are made palatable, moreover, to the

for the Safety of Life at Sea, Nov. 1, 1974, art. VIII(b) (vii)(2), 32 U.S.T. 47, 52, 1184 U.N.T.S. 277, 281.

72. See Note, supra note 15 , at $1103 \&$ n.19 (noting infrequency with which states opt out under these and similar arrangements).

73. Article 2.9(c) provides that, after attempts to reach consensus have failed, adjustment to the limits to chemicals specified in the Annexes may "as a last resort" be adopted by a two-thirds majority, including a majority each of developing country and developed country constituencies. Montreal Protocol on Substances that Deplete the Ozone Layer, Sept. 19, 1987, art. 2.9(c), S. Treaty Doc. No. 100-10, at 19-20, 1522 U.N.T.S. 28, 33 [hereinafter Montreal Protocol]; id. art. 2.9(d), S. Treaty Doc. No. 100-10, at 20, 1522 U.N.T.S. at 33 (providing that such decisions "shall be binding on all Parties"); see Richard E. Benedick, Ozone Diplomacy 90 (1998) (citing appraisal that method of adjustment was a "'great novelty in international environmental law"” (quoting Johan G. Lammers, Second Report of the Internal Committee on Legal Aspects of Long-Distance Air Pollution, Address at the International Law Association, Warsaw Conference (1988))); Johan Lammers, The Mechanism of Decision-making Under the Vienna Convention and the Montreal Protocol for the Protection of the Ozone Layer, in State, Sovereignty, and International Governance 407, 412 (Gerard Kreijen et al. eds., 2002) [hereinafter Lammers, Mechanism of Decision-Making] (describing adjustment method as "an extraordinary mechanism of decision-making"). The parties distinguished, however, between adjustments to known, previously addressed chemicals-which the parties expected to be eliminated-and controls on new chemicals, which were to be added only for those parties ratifying the amendments. Benedick, supra, at 88-91; Széll, supra note 70 , at 213.

74. Protocol Additional to the Agreement Between the United States of America and the International Atomic Energy Agency for the Application of Safeguards in the United States of America, June 12, 1998, U.S.-IAEA, art. 16(b), S. Treaty Doc. No. 107-7, at 21, 31 (2002) [hereinafter U.S.-IAEA Additional Protocol]; see Statute of the International Atomic Energy Agency, opened for signature Oct. 26, 1956, art. VI(e), 8 U.S.T. 1093, 1100, 276 U.N.T.S. 3, 16 (providing for majority voting on nonbudgetary questions, upon a twothirds quorum). Article 9 of the Protocol also allows the IAEA access to locations it specifies, following consultations with the United States, subject to arrangements approved by the same qualified majority of the Board. U.S.-IAEA Additional Protocol, supra, art. 9, S. Treaty Doc. No. 107-7, at 28.

75. Congressional Research Service, 106th Cong., Treaties and Other International Agreements: The Role of the United States Senate, S. Prt. No. 106-71, at 182 (Comm. Print 2001) [hereinafter CRS] (attributing acceptance of unorthodox amendment procedures to technical character and complexity of some arms control and environmental agreements). For an account of how the increasingly technical character of arms control 
extent that parties may enter reservations to amendments. ${ }^{76}$ Nonetheless, such amendments may change the parties' substantive obligations to a degree that rivals or exceeds any nontechnical developments. ${ }^{77}$ Adjustments to the Montreal Protocol regime, for example, transformed the parties' obligation to reduce production and consumption of chlorofluorocarbons (CFCs). ${ }^{78}$ And the ease of rendering technical

treaties fostered the development of "non-amendment amendments," see Koplow, supra note 15 , at $990-1004,1009$.

76. This has proven to be a particularly serious issue for CITES, in which the ease of amending appendices has been offset by the ease of reservations-typically entered by the nations most instrumental to the regime's success. See Philippe J. Sands \& Albert P. Bedecarré, Convention on International Trade in Endangered Species: The Role of Public Interest Non-Governmental Organizations in Ensuring the Effective Enforcement of the Ivory Trade Ban, 17 B.C. Envtl. Aff. L. Rev. 799, 804-05 (1990) (noting detrimental effects of reservation clauses on certain endangered species); see also Resolution on Effects of Reservations (Conf. 4.25) (1983) (adopted at Fourth Meeting of the Conference of the Parties, Apr. 19-30, 1983, Gaborone, Botswana), available at http://www.cites.org/eng/ resols/4/4_25.shtml (on file with the Columbia Law Review) (noting that reservations practice "has led to different interpretations of the Convention by the parties"). It is unclear whether broader developments in the law and practice regarding reservations, including the authority of constituent organizations to disapprove reservations, will have any material impact. See Chris Wold, Implementation of Reservations Law in International Environmental Treaties: The Cases of Cuba and Iceland, 14 Colo. J. Int'l Envtl. L. \& Pol'y 53, 115-18 (2003) (urging greater attention by member states to contemporary developments).

Some treaties offer the lesser option of seeking a temporary waiver or exemption, which-like provisions governing reservations-vary as to their conditions. For example, the Montreal Protocol bans reservations, see Montreal Protocol, supra note 73, art. 18, but as amended includes substances (like methyl bromide) that are subject to "critical use" exceptions. Amendment to the Montreal Protocol on Substances that Deplete the Ozone Layer, Nov. 25, 1992, art. 2(H) (5), S. Treaty Doc. No. 103-9, at 21-22, available at http:// www.unep.org/ozone/pdf/Montreal-Protocol2000.pdf (on file with the Columbia Law Review); Juliet Eilperin, U.S. to Seek Further Waiver for Ozone-Harming Pesticide, Wash. Post, July 13, 2004, at A3; see also Convention on Psychotropic Substances, Feb. 21, 1971, arts. 2(5), 2(7), 17(2), 32 U.S.T. 543, 548-49, 562, 1019 U.N.T.S. 175, 178-79, 189 (providing for the nonconsensual, automatically effective addition of controlled substances, but allowing that "exceptional circumstances" may exempt a party from complying if it agrees to minimal control measures).

77. Churchill \& Ulfstein, supra note 3, at 638 (citing examples of significant technical amendments to CITES and to the London Convention).

78. While the original obligation was to reduce CFCs to one half of 1986 levels by 1999, subsequent meetings of the Parties provided instead that they should be phased out completely by 1996. U.N. Environment Programme, Report of the Fourth Meeting of the Parties to the Montreal Protocol on Substances that Deplete the Ozone Layer, Annexes I, II, U.N. Doc. UNEP/OzL.Pro.4/15 (1992); id. Decisions IV/2, IV/3; U.N. Environment Programme, Report of the Second Meeting of the Parties to the Montreal Protocol on Substances that Deplete the Ozone Layer, Annex I, U.N. Doc. UNEP/OzL.Pro.2/3, (1990); id. Decision II/1; see also Churchill \& Ulfstein, supra note 3, at 638 (asserting that "[s]imilar far-reaching changes have subsequently been required for the use of other 
amendments to the IAEA Additional Protocol, which contrasts with the veto preserved under the prior safeguards agreement between the United States and IAEA, ${ }^{79}$ is noteworthy in light of the greater intrusiveness of the Additional Protocol ${ }^{80}$ and the recent controversies surrounding international weapons inspections. ${ }^{81}$

\section{B. Delegations of Authority to Legislate}

A second category of institutional authorities more closely resembles ordinary legislation. The UN Security Council, for example, has the authority to order member nations to adopt embargoes and other sanctions, ${ }^{82}$ and since the end of the Cold War has been more at liberty

ozone-depleting substances listed" in Protocol Annexes); Lammers, Mechanism of Decision-Making, supra note 73, at 413 (claiming that "the adjustment procedure . . has been one of the decisive factors of the successful development of the Montreal Protocol"); id. at 413-19 (citing examples of adjustments); Ozone Secretariat, U.N. Environment Programme, Adjustments to Montreal Protocol (2003), at http://www.unep.ch/ozone/ Treaties_and_Ratification/montreal_protocol/adjustments_MontrealProt.asp (on file with the Columbia Law Review) (compiling adjustments).

79. Agreement Between the United States of America and the International Atomic Energy Agency for the Application of Safeguards in the United States of America, Nov. 18, 1977, U.S.-IAEA, art. 23(b), 32 U.S.T. 3059, 3069 ("All amendments shall require the agreement of the United States and the Agency.”); id. art. 39(d), 32 U.S.T. at 3074 (providing that certain "Subsidiary Arrangements may be extended or changed by agreement between the Agency and the United States" without formally amending the Agreement).

80. Barry Kellman \& Stephen Dycus, International Security, 33 Int'l Law. 591, 600 (1999) (describing Additional Protocol as a "substantially different document than its predecessor" in terms of facilities covered, "far more expansive" authority to conduct verification activities, and expanded responsibilities for U.S. government).

81. See, e.g., id. at 599 (citing changes in IAEA procedures since discovery of Iraqi and North Korean nuclear programs).

82. U.N. Charter art. 41 (authorizing the Security Council to adopt "measures not involving the use of armed force . . . to give effect to its decisions," and to call upon UN members to apply such measures, including the "complete or partial interruption of economic relations" and means of communication, and "the severance of diplomatic relations"); id. arts. 48-49 (obliging members to carry out such decisions). Congress has specifically acknowledged U.S. obligations to comply. United Nations Participation Act, 22 U.S.C. \$287c (2000). Article 25 of the UN Charter requires compliance with Security Council decisions of comparable gravity even outside the purview of Chapter VII. See Legal Consequences for States of the Continued Presence of South Africa in Namibia (South West Africa) Notwithstanding Security Council Resolution 276 (1970), 1971 I.C.J. 16, 51-53 (June 21) (outlining member state obligation to comply with Security Council Resolution declaring illegal South African presence in Namibia); Rosalyn Higgins, The Advisory Opinion on Namibia: Which UN Resolutions Are Binding under Article 25 of the Charter?, 21 Int'l \& Comp. L.Q. 270 (1972) (debating whether Article 25 applies only to Security Council decisions taken under Chapter VII). 
to do so. ${ }^{83}$ The most striking recent example was Security Council Resolution 1373, which compelled all nations-not just Security Council members, nor even solely UN members-to take specific actions against the financing of terrorist activities. ${ }^{84}$ One expert described the resolution as the first use of Chapter VII authority "to order all states to take or to refrain from specified actions in a context not limited to disciplining a particular country," 85 and further speculated that "it seems likely to constitute a precedent for further legislative activities" by the Security Council and other international institutions. ${ }^{86}$ Resolution 1422, which provided immunity for a renewable twelve-month period to personnel involved in UN operations hailing from nations not party to the ICC, 87 and Resolution 1540 , which adopted a broad nonproliferation agenda, ${ }^{88}$ arguably bear out that prediction. Critics of such measures argue that they exceed the Council's authority ${ }^{89}$ and circum-

83. See, e.g., W. Michael Reisman, The Constitutional Crisis in the United Nations, 87 Am. J. Int'l L. 83, 85 (1993) ("Now . . the Cold War has ended and, suddenly, the Council, by national or international governmental standards, seems remarkably effective."). The Council thus joins other, less ideologically driven security arrangements possessing such authority. See N.D. White, The Law of International Organisations 87-89 (1996).

84. S.C. Res. 1373, U.N. SCOR, 56th Sess., 4385th mtg., U.N. Doc. S/RES/1373 (2001).

85. Szasz, supra note 29, at 901; see also Jose E. Alvarez, Hegemonic International Law Revisited, 97 Am. J. Int'l L. 873, 874 (2003) [hereinafter Alvarez, Hegemonic International Law] (describing Resolution 1373 as "that rare phenomenon in international law: legally binding regulation, backed by the possibility of real enforcement action, imposed on all states by a global international organ engaged in a continuous legislative enterprise by virtue of delegated power and subject to no geographic or temporal limitation").

86. Szasz, supra note 29 , at 905 .

87. S.C. Res. 1422, U.N. SCOR, 57th Sess., 4572d mtg., U.N. Doc. S/RES/1442 (2002) (requesting cooperation from the ICC in refraining from investigating or prosecuting referenced cases, expressing the intention to renew requests for successive periods "for as long as may be necessary," and deciding that member states "shall take no action inconsistent [with the requested immunity] and with their international obligations"). Resolution 1422 was in fact renewed only once, see S.C. Res. 1487, U.N. SCOR, 58th Sess., 4772d mtg., U.N. Doc. S/RES/1487 (2003), before encountering serious opposition. See infra text accompanying note 421 .

88. S.C. Res. 1540, U.N. SCOR, 59th Sess., 4956th mtg., U.N. Doc. S/RES/1540 (2004).

89. See, e.g., Matthew Happold, Security Council Resolution 1373 and the Constitution of the United Nations, 16 Leiden J. Int'l L. 593, 593-601 (2003) (criticizing Security Council Resolution 1373 as predicated on indefinite threat to international peace and security); Carsten Stahn, The Ambiguities of Security Council Resolution 1422 (2002), 14 Eur. J. Int'l L. 85, 86-87 (2002) (criticizing Security Council Resolution 1422 as lacking a sufficiently specific and direct predicate finding of a threat to international peace and security); Human Rights Watch, The ICC and the Security Council: Resolution 1422 (2004), at http://www.hrw.org/campaigns/icc/docs/1422legal.pdf (on file with the Columbia Law Review) (same). 
vent both multilateral treatymaking ${ }^{90}$ and the General Assembly ${ }^{91}$ in the process.

The Security Council is not so singular as it may appear. The OECD, for example, has issued some twenty decisions establishing new, binding norms for its members on subjects such as multinational enterprises, bribery, and transboundary waste shipments. ${ }^{92}$ And the WTO's Ministerial Conference has the authority, upon petition by a member and approval by a majority of the membership, to adopt decisions on matters within the purview of its trade agreements. ${ }^{93}$ This may be the most plausible basis for the Doha Declaration on the TRIPS (Trade-Related Aspects of International Property Rights) Agreement and Public Health, a significant modification of the existing understanding of the TRIPS Agree-

90. E.g., Alvarez, Hegemonic International Law, supra note 85, at 874-75; see Ilias Bantekas, The International Law of Terrorist Financing, 97 Am. J. Int'l L. 315, 326 (2003) (describing Security Council Resolution 1373 as "minitreaty"). This point was made with particular force in the open debate on Resolution 1540 by member states not belonging to the Security Council-and by member states not party to one or the other of the relevant nonproliferation treaties. U.N. SCOR, 59th Sess., 4950th mtg. at 8, U.N. Doc. S/PV.4950 (2004) (Resumption 1) (Provisional) (representative of Korea); U.N. SCOR, 59th Sess., 4950th mtg. at 15, U.N. Doc. S/PV.4950 (2004) (Provisional) (representative of Pakistan) [hereinafter 4950th Meeting]. Opting for the Security Council has practical significance. In the case at hand, Resolution 1373 largely mirrored the provisions of the 1999 Convention for the Suppression of the Financing of Terrorism, yet lacked the Convention's definition of terms like terrorism- "thus granting the Committee very substantial discretion in interpreting the extent of states' obligations under the resolution." Happold, supra note 89 , at 594. More generally, states have a choice as to whether to become parties to a treaty, but do not have such latitude with respect to Security Council legislation. Id. at 594-95. Moreover, nations ratifying a treaty often have the opportunity to lodge reservations, understandings, or declarations (RUDs) differentiating their obligations, while that option is not again available with respect to the Security Council. See, e.g., Multilateral Treaties Deposited with the Secretary-General, International Convention for the Suppression of the Financing of Terrorism, at http:// untreaty.un.org/ENGLISH/Status/Chapter_xviii/treaty11.asp (last visited Aug. 29, 2004) (on file with the Columbia Law Review) (detailing reservations, understandings, objections, and notifications).

91. See 4950th Meeting, supra note 90, at 23 (noting concern of representative of India regarding "the increasing tendency of the Council . . . to assume new and wider powers of legislation on behalf of the international community, with its resolutions binding on all States," and that "the exercise of legislative functions by the Council, combined with recourse to Chapter VII mandates, could disrupt the balance of power between the General Assembly and the Security Council, as enshrined in the Charter"); accord id. at 31 (representative of Indonesia); id. at 32 (representative of Iran).

92. Convention on the Organization for Economic Co-operation and Development, Dec. 14, 1960, art. 5 (a), 12 U.S.T. 1728, 1734, 888 U.N.T.S. 179, 185 (compiling decisions). Such decisions must be by consensus absent unanimous agreement that an alternative rule is to be employed. Id. art. 6, 12 U.S.T. at 1734, 888 U.N.T.S. at 185 . Some contend that other OECD instruments, such as recommendations, are binding in a somewhat lesser sense. See Edward T. Swaine, The Local Law of Global Antitrust, 43 Wm. \& Mary L. Rev. 627, $728 \&$ n.398 (2001) [hereinafter Swaine, Global Antitrust] (citing authorities).

93. See WTO Agreement arts. IV(1), IX(1). 
ment,${ }^{94}$ which prompted one commentator to query whether "a legislative body has begun to formulate world trade law."95 As if to reply, the WTO General Council-the highest-level decisionmaking body located in Geneva, which acts on behalf of the Ministerial Conference between its biennial meetings-issued an interim waiver that purported to restate member obligations, again, until such point as a formal amendment to TRIPS can be completed. ${ }^{96}$ Each power resembles one that the U.S. Congress might exercise under the Commerce Clause. ${ }^{97}$

94. In part because the precise legal basis for the Doha Declaration is uncertain, its legal import is also unclear. Given the decision to refrain from amending the WTO under Article X, and to refrain from adopting an interpretation under Article IX(2), it seems likely that the Declaration did not change the legal obligations of WTO members. Steve Charnovitz, The Legal Status of the Doha Declarations, 5 J. Int'l Econ. L. 207, 210 (2002). But it may nonetheless be cited in dispute settlement as evidence of a subsequent agreement among the parties concerning the application of treaty provisions, or as evidence of subsequent practice bearing on treaty interpretation. Id. at 211; James Thuo Gathii, The Legal Status of the Doha Declaration on TRIPS and Public Health Under the Vienna Convention on the Law of Treaties, 15 Harv. J.L. \& Tech. 291, 299 (2002); see VCLT, supra note 65, art. 31(3)(a), 1155 U.N.T.S. at 340 (providing that any subsequent agreement between treaty parties "regarding the interpretation of the treaty or the application of its provisions" is relevant to its interpretation); id. art. 31(3)(b), 1155 U.N.T.S. at 340 (providing that "subsequent practice . . establishes the agreement of the parties regarding its interpretation").

95. Charnovitz, supra note 94, at 211 (considering that Doha Declarations may be "part of the constitutive process of decision-making by the WTO as an organization," entailing exercise of Ministerial Conference's "constitutional authority to set WTO policy, or perhaps to enact secondary law").

96. WTO General Council, Implementation of Paragraph 6 of the Doha Declaration on the TRIPS Agreement and Public Health, Aug. 30, 2003, WT/L/540 (Sept. 2, 2003), available at http://docsonline.wto.org/DDFDocuments/t/WT/L/540.doc (on file with the Columbia Law Review). The meaning was then further amplified by a separate statement by the Council chair. See WTO General Council, Minutes of Meeting, Aug. 25, 26, 30, 2003, I 29, WT/GC/M/82 (Nov. 13, 2003) (statement of Carlos Pérez del Castillo, Chair, WTO General Council), available at http://docsonline.wto.org/DDFDocuments/t/ WT/GC/M82.doc (on file with the Columbia Law Review).

97. Some delegations also implicate more specific Article I powers. For example, the UN Security Council's authority to obligate the United States to employ its "air, sea, or land forces," U.N. Charter art. 42; see id. art. 25 (obliging members to "accept and carry out" Security Council decisions), could be seen as an impermissible constraint on Congress's authority to declare war. The question depends in part on one's interpretation of the constitutional allocation of war powers. See Bradley, International Delegations, supra note 3 , at $1568-70$ (noting controversy and its relevance to delegation and separation of powers issues); see, e.g., Michael J. Glennon, Presidential Power to Wage War Against Iraq, 6 Green Bag 183, 184 (2003) (doubting whether "the Charter gives the Security Council the power to order member states to use force" and whether "this power, assigned by the Constitution to the Congress and the President, can be delegated to an international organization"). But in any case, Congress has attempted to rein in any delegation by denying the President authority to make armed forces available without prior authorization, see United Nations Participation Act $§ 6,22$ U.S.C. $§ 287 d$ (2000) (expressly limiting authorizing language of the Act to say that it does not constitute general delegation to President to make armed forces available to Security Council), and reinforcing the bias against any treaty-dictated military activities in the War Powers 


\section{International Assimilations}

A third category of delegations involves the indirect "assimilation" of international acts. ${ }^{98}$ Assimilative statutes do not, in and of themselves, assign legislative authority to any international actor. Instead, they direct the President or other executive branch officials to abide by, or otherwise take into account, lawmaking by international institutions.

The U.S. Code is replete with international assimilations, many of them simply informational or otherwise incidental. ${ }^{99}$ But some have proven controversial. For example, in signing the recently enacted Clean Diamond Trade Act, President Bush highlighted a "serious question" as to whether predicating the Act's effective date on permission from the

Resolution, 50 U.S.C. $\$ 1547$ (a) (2) (2000). Bradley, International Delegations, supra note 3 , at $1569-70 \&$ n. 57 .

The UN General Assembly also enjoys the authority to apportion financial responsibility for UN expenses, U.N. Charter art. 17, para. 2, and if a member state goes too far into arrears it risks losing its vote, id. art. 19; see Sean D. Murphy, Payment of U.S. Arrears to the United Nations, 94 Am. J. Int'l L. 348, 348 \& n.3 (2000) (giving examples of failure to enforce Article 19 disenfranchisement against prior debtors United States and Soviet Union). Some suggest that " $[\mathrm{t}]$ he United States . . . has an international legal obligation to pay such assessments and Congress is constitutionally obligated to appropriate money to pay them." Henkin, Foreign Affairs, supra note 15, at 259. If so, the General Assembly's authority arguably encroaches on Congress's taxing and spending power, U.S. Const. art. I, $\$ 8$, cl. 1 ("The Congress shall have Power to lay and collect Taxes, Duties, Imposts and Excises.”), and violates the Origination Clause, id. art. I, § 7, cl. 1 ("All Bills for raising Revenue shall originate in the House of Representatives."). Such objections may, to be sure, have political traction. See, e.g., 146 Cong. Rec. H4787, H4796-97 (daily ed. June 21, 2000) (statement of Rep. Chenoweth-Hage) (arguing that WTO decision finding illegal U.S. tax provisions amounted to "unconstitutional delegation of taxing authority to an unelected international body of international bureaucrats"). In general, though, implicating specific sources of legislative authority adds little to the objection that the Constitution vests legislative authority in Congress that must remain its own. See Loving v. United States, 517 U.S. 748, 767-78 (1996) (finding no basis for limiting delegation where "power is no less plenary than other Article I powers"); Skinner v. Mid-Am. Pipeline Co., 490 U.S. 212, 220-21 (1989) (explaining that delegations of Taxing Clause authority should be judged by same standards as delegations of other legislative powers).

98. The term "assimilation" is used by Congress and the Supreme Court in the domestic context. See United States v. Sharpnack, 355 U.S. 286, 288, 293-94 (1958) (upholding Assimilative Crimes Act of 1948, providing for the punishment of " 'any act or omission which, although not made punishable by any enactment of Congress, would be punishable if committed or omitted within the jurisdiction of the State, Territory, Possession, or District in which such place is situated," against nondelegation challenge (quoting 18 U.S.C. $\$ 13(2000))$ ). Professor Ku has helpfully drawn attention to the potential issue for international delegations, though his discussion is limited to a hypothetical in which the UN Human Rights Committee undertook to define terms relevant to U.S. statutes. Ku, supra note 15 , at 105-07.

99. See, e.g., Iran and Libya Sanctions Act of 1996, 110 Stat. 1541, 50 U.S.C. § 1701, amended by ILSA Extension Act of 2001, Pub. L. No. 107-24, §§ 2(a), 3-5, 115 Stat. 199, 200 (requiring President to notify relevant congressional committee when a listed nation adopts sanctions on Iran or Libya, when and how sanctions are applied, and how those sanctions fare under any WTO or GATT review). 
WTO or the UN Security Council "unconstitutionally delegated legislative power to international bodies," which he sought to avoid by construing his certification (and its duration) as wholly discretionary. ${ }^{100}$ Similarly, the Bush Administration has reportedly suggested that proposed legislation to implement treaties on persistent organic pollutants (POPs) would violate an "international nondelegation doctrine," "rais[ing] . . . constitutional concerns," by making EPA rulemaking as to new chemical listings dependent on international regulatory processes. ${ }^{101}$

These controversies suggest a new temper toward international delegations, particularly since domestic and foreign assimilations have traditionally received less scrutiny. Numerous cases have upheld the constitutionality of the Lacey Act, for example, which criminalizes trade in wildlife in violation of federal, state, foreign, or tribal law, ${ }^{102}$ even though the Act appears to imbue such laws-including those adopted after its passage- -with the status of federal law. The basis of these decisions is the notion that the state, foreign, or tribal law is "simply a factual predicate for the application of federal law"103_as one court put it, "a fact entering

100. Statement on Signing the Clean Diamond Trade Act, 39 Weekly Comp. Pres. Doc. 491 (Apr. 25, 2003); see also infra text accompanying notes 514-515 (evaluating purported solution). Section 15 of the Act provides that the Act shall take effect once the President certifies that an applicable waiver granted from the WTO or an applicable Security Council resolution is in effect. Clean Diamond Trade Act, Pub. L. No. 108-19, $\S 15,117$ Stat. 631, 637 (2003) (to be codified at 19 U.S.C. $\$ 3901$ ). For a similar provision, see Uruguay Round Agreements Act of 1994, Pub. L. No. 103-465, § 101(b) (codified as amended at 19 U.S.C. $\$ 3511$ (b) (2000)) (providing that when "the President determines that a sufficient number of foreign countries are accepting the obligations of the Uruguay Round Agreements ... the President may accept the Uruguay Round Agreements and implement article VIII of the WTO Agreement").

101. Memorandum from Glenn Wiser, Senior Attorney, Center for International Environment Law, Analysis of Department of Justice Letter Regarding the Constitutionality of Mandatory Notice and Comment Provisions Proposed in Implementing Legislation for the Stockholm Convention on Persistent Organic Pollutants (POPs) § 3(C), at 5, 6 (Apr. 5, 2004), available at http://www.ciel.org/POPs/Memorandum_Stockholm_5Apr04.html (on file with the Columbia Law Review) (responding to Bush Administration objections that requirement for public participation and comment would unconstitutionally delegate lawmaking powers to international bodies); see Letter from William Moschella, Assistant Attorney General, Office of Legislative Affairs, U.S. Department of Justice, to Tom Harkin, U.S. Senator 4 (Mar. 25, 2004) (on file with the Columbia Law Review) (distinguishing alternative bill that, inter alia, "is not linked to decisions in the international process [and thus] does not raise the same constitutional concerns"). The Senate bill in question would require the EPA to publish notices and solicit information at several stages of the international treaty-based review of new chemical listings, require it to give substantial weight in any rulemaking to international recommendations and decisions, and permit petitioning of the EPA to commence rulemaking one year after an international listing. POPs, LRTAP POPs, and PIC Implementation Act of 2003, S. 1486, 108th Cong. \$ 502 (2004); POPs, LRTAP POPs, and PIC Implementation Act of 2003, S. Rep. No. 108-256, at 4-6 (2004).

102. 16 U.S.C. $\$ 3372$ (a) (2000).

103. $\mathrm{Ku}$, supra note 15 , at 106 . Thus, although the Lacey Act entails reference to laws promulgated after its enactment, it does not involve conditions subsequent to the conduct in question. As one court of appeals decision emphasized, changes in foreign law-and 
into the description of the contraband article, just as if importations of wine or automobiles were restricted to bottles bearing an official foreign designation of appellation controllée or cars bearing indicia of a foreign safety inspection"104_rather than an assignment of authority to state, foreign, or tribal legislators. ${ }^{105}$

However thin this premise, ${ }^{106}$ it seems defensible only if Congress is disengaged from the referenced law and the circumstances of its enactment. ${ }^{107}$ But most statutes involving the assimilation of international acts are not so freestanding; instead, they are preceded by a primary delegation to an international institution, the byproducts of which the assimilative statute then implements. Indeed, many of the more controversial

changes in a foreign government's views as to the validity of its law-are irrelevant if they occur after the constituent act. United States v. McNab, 331 F.3d 1228, 1241 (11th Cir. 2003), cert. denied, 124 S. Ct. 1406 (2004); see id. at 1242 (noting prospect that defendants might influence foreign governments to invalidate laws serving as the basis for U.S. convictions). Changes in foreign law remain salient, of course, as to subsequent acts. But the United States and its courts are entirely passive, and need not even monitor postact developments, in contrast to the continuing U.S. involvement in international institutions. Cf. id. (stressing that " $[\mathrm{t}]$ he district courts and the government of the United States ... have the right to rely upon the [foreign] government's original verifications of its laws").

104. United States v. Molt, 599 F.2d 1217, 1219 n.1 (3d Cir. 1979).

105. See, e.g., United States v. Lee, 937 F.2d 1388, 1393-94 (9th Cir. 1991) (rejecting claim that criminalizing "trade in fish and wildlife 'in violation of any foreign law' . . . unconstitutionally delegates congressional power to foreign governments," on grounds that " the [United States] government is not applying the foreign law per se, but rather it is looking to the foreign law to determine if the Act's provisions are triggered; if so, then it will apply the Act, and not the foreign law'" (quoting United States v. 594,464 Pounds of Salmon, 871 F.2d 824, 830 (9th Cir. 1989))); id. (citing other circuits); see also United States v. Sharpnack, 355 U.S. 286, 294 (1958) (holding that statutory incorporation of "future state legislative action in connection with the exercise of federal legislative power" to apply state criminal law in federal enclaves did not delegate congressional legislative power); The Constitutional Separation of Powers Between the President and Congress, 20 Op. Off. Legal Counsel 124, 177 n.134 (1996) ("[T] here is no separation of powers problem with legislation that defines a federal rule of law by reference to state or foreign law."). See generally Clinton v. City of New York, 524 U.S. 417, 444-45 (1998) (differentiating as nonlegislative tariff and import statutes that provided for suspension or repeal of particular provisions based on certain conditions, leaving to the President only determination of whether those conditions had transpired); J.W. Hampton, Jr., \& Co. v. United States, 276 U.S. 394, 407 (1928) ("Congress may feel itself unable conveniently to determine exactly when its exercise of the legislative power should become effective, because dependent on future conditions, and it may leave the determination of such time to the decision of an Executive ....").

106. It is difficult to imagine, for example, that a statute imposing civil penalties on all activities contravening a resolution passed by an international assembly would not be understood as a delegation of legislative authority.

107. Absent that condition, Congress could circumvent more conventional applications of the nondelegation doctrine by establishing an executive branch office with relatively uncircumscribed authority, then enacting a statute purporting to treat as federal law anything the executive officer did. In the Lacey Act, notably, Congress is the passive recipient of the foreign law, not its enabler. 16 U.S.C. § 3372. 
international delegations are paired with such assimilative statutes, ${ }^{108}$ including a number of delegations that operate by less consensual or transparent means. ${ }^{109}$ Assimilations of this kind arguably raise few problems that are distinct from the primary delegation. At the same time, such couplings undermine the notion that delegations lack domestic legal pertinence and, if nothing else, help demarcate delegations of interest. ${ }^{110}$

\section{Customary International Law}

A fourth form of international delegation involves customary international law-the rules that nations appear to accept as legally binding upon them. ${ }^{111}$ This is a distinctive type of delegation, unique to the international setting, and the circumstances require careful specification. For example, while some have suggested that enforcing such law in U.S. courts necessarily entails a legally problematic delegation, ${ }^{112}$ that account

108. See, e.g., Tariff Act $\$ 516(A), 19$ U.S.C. $\$ 1516 a(g)(7)(A)$ (2000) (implementing Chapter 19 of NAFTA by providing that when Chapter 19 arbitration panel refers challenged matter on antidumping or countervailing duties back to International Trade Commission (ITC), ITC shall "take action not inconsistent with the decision"); Chemical Weapons Convention Implementation Act § 305, 22 U.S.C. § 6725 (2000) (implementing Chemical Weapons Convention by requiring State Department to seek issuance of search warrant in response to demand from Organization for the Prohibition of Chemical Weapons (OPCW) to engage in challenge inspection of public or private facility).

109. See, e.g., Federal Food, Drug, and Cosmetic Act, 21 U.S.C. \$ 346a(b) (4) (2000) (providing that FDA Administrator must publish for comment any reasons for departing from maximum pesticide residue level established by Codex Alimentarius Commission); Pelly Amendment to Fishermen's Protective Act of 1967 (codified as amended at 22 U.S.C. $\S 1978(\mathrm{a})(1)$, (2)) (providing for agency certification to the President upon a determination that foreign nationals are impairing the effectiveness of any "international fishery conservation program" or "international program for endangered or threatened species"); id. \$1978(a)(4) (providing that upon receiving certification, the President may prohibit imports "of any products from the offending country for any duration as the President determines appropriate and to the extent that such prohibition is sanctioned by the $[\mathrm{WTO}]$... or the [specified] multilateral trade agreements"); Clean Air Act, 42 U.S.C. $\S 7671 \mathrm{e}(\mathrm{a})$ (3) (2000) (providing that in the event the Montreal Protocol "is modified to . . . control or reduce . . . any substance more rapidly [than otherwise provided by law]," the EPA shall establish a more stringent phase-out schedule); id. $\$ 7671 \mathrm{~m}$ (b) (providing that subchapter is to be construed consistent with U.S. obligations under Montreal Protocol, and that in event of conflict, the more stringent provision is to govern).

110. See infra notes 184-203 and accompanying text (addressing purported lack of legal relevance).

111. See Statute of the International Court of Justice, June 26, 1945, art. 38, 59 Stat. 1055, 1060, 3 Bevans 1153, 1187 [hereinafter ICJ Statute] (directing courts to "apply . . . international custom, as evidence of a general practice accepted as law"); Restatement of the Law (Third) of the Foreign Relations Law of the United States § 102(2) (1987) ("Customary international law results from a general and consistent practice of states followed by them from a sense of legal obligation.”).

112. See, e.g., Rabkin, supra note 16 , at 62 (describing customary international law as "in itself, a wholesale delegation of lawmaking power (or treatymaking power) of just the sort that . . . the Constitution would otherwise seem to forbid"). To be clear, Professor Rabkin does not agree that customary international law should be construed to have that effect. See id. at 56-62. For representative views in the debate, compare, e.g., Curtis A. 
is incomplete: Even if the courts have given customary international law a preemptive and legislative character, a nondelegation offense requires, at a minimum, that Congress was involved in assigning its authority. ${ }^{113}$

It is perhaps easiest to discern such assignments on the international plane. First, the United States has helped form international institutions that themselves create customary international law or generate the opinio juris and state practice undergirding it. ${ }^{114}$ Whether the resolutions and recommendations of international organizations instead ought to be re-

Bradley \& Jack L. Goldsmith, Customary International Law as Federal Common Law: A Critique of the Modern Position, 110 Harv. L. Rev. 815 (1997) (arguing that customary international law should not, without authorization from the federal political branches, have the status of federal law), with Harold Hongju Koh, Comment, Is International Law Really State Law?, 111 Harv. L. Rev. 1824 (1998) (arguing that customary international law is properly regarded as federal common law).

113. And, I assume, requires more than an attenuated claim that Congress has failed to curtail a judicial practice - at least to the extent of its authority to do so. Cf. Jordan J. Paust, International Law as Law of the United States 9 (2d ed. 2003) (suggesting that "customary international law can limit the exercise of an otherwise appropriate congressional power"). One might argue that Congress indirectly contributes to customary international law each and every time it opines on a matter of international concern. See, e.g., Brief for the United States as Respondent Supporting Petitioner at 39, Sosa v. Alvarez-Machain, 159 L. Ed. 2d 718 (2004) (No. 03-339) (conceding that "[a]lthough the political branches cannot control the development of customary international law," they may influence it through "diplomatic and military measures, formal pronouncements, negotiation of international agreements, and the announcement of reservations or conditions to the ratification of such agreements, or to general standards of international law that may be asserted by other nations"); Restatement (Third) of Foreign Relations Law of the United States $\$ 102 \mathrm{cmt}$. b (including unilateral governmental measures and official statements of policy as evidencing relevant state practices). But identifying this kind of derivative effect as a delegation would strip the term of any coherent meaning.

Even absent any meaningful congressional delegation of authority, the critics of customary international law would nonetheless argue that it poses problems of constitutional concern. See, e.g., Bradley, International Delegations, supra note 3, at 1580-81 (arguing that attributing federal law status to custom "would give unelected federal judges broad lawmaking authority not stemming from any political branch authorization, in areas in which they may have limited institutional competence"); Young, Trouble, supra note 3, at 533-34 (asserting that irrespective of whether it would be prohibited under the Constitution, "there is no serious question that giving direct effect to customary norms works a profound departure from the ordinary procedure by which law is made in this country").

114. See, e.g., Comm. on Formation of Customary (Gen.) Int'l Law, Int'l Law Ass'n, Final Report: Statement of Principles Applicable to the Formation of General Customary International Law $\$ \S 28-33$ (2000), available at http://www.ila-hq.org/pdf/Customary Law.pdf (on file with the Columbia Law Review) (describing function of General Assembly resolutions in relation to customary international law). It is important to note that, even if resolutions and their like do not contribute to custom, they yet have legal effect, such as by affording safe harbor to those complying with them. Bowett's Law of International Institutions, supra note 32, at 279-92 (describing potential legal effect of recommendations, resolutions, declarations, and unratified conventions); Schermers \& Blokker, supra note 42, at $\$ \S 1216-1280$ (same); Christoph Schreuer, Recommendations and the Traditional Sources of International Law, 20 German Y.B. Int'l L. 103, 118 (1977). 
garded only as "soft law" is beyond the scope of this Article, ${ }^{115}$ but it suffices to note that international tribunals have sometimes given them a more exalted status, ${ }^{116}$ putting Congress on notice as to the consequences of conferring authority. Second, Congress has assented to international institutions that purport only to apply, rather than to make, customary international law. The most prominent example is the International Court of Justice (ICJ), ${ }^{117}$ to which the United States partially acquiesces, ${ }^{118}$ even though the ICC-which the United States is no longer likely to join-would have rivaled it. ${ }^{119}$

NAFTA illustrates the permeability of any distinction between making and applying customary international law. Chapter 11 provides for the creation of arbitral panels to assess whether any of the three state parties have infringed the rights of foreign investors. ${ }^{120}$ The panels' duties include the construction of ambiguous treaty terms ${ }^{121}$ that are pur-

115. For examples of the literature on this question, see Swaine, Global Antitrust, supra note 92 , at 728 n.400.

116. See, e.g., Advisory Opinion on the Legality of the Threat or Use of Nuclear Weapons, 1996 I.C.J. 226, 254-55 (July 8) ("General Assembly resolutions, even if they are not binding . . . can, in certain circumstances, provide evidence important for establishing the existence of a rule or the emergence of an opinio juris."); Military and Paramilitary Activities in and Against Nicaragua (Nicar. v. U.S.), 1986 I.C.J. 14, 99-103, 106-09 (June 27) (requiring little affirmative evidence of state practice in light of General Assembly instruments evidencing opinio juris on principle of nonintervention).

117. See ICJ Statute, supra note 111, art. 38, 59 Stat. at 1060, 3 Bevans at 1187 (directing ICJ to "apply . . . international custom, as evidence of a general practice accepted as law”); Bradley, International Delegations, supra note 3, at 1570-73. To be clear, Professor Bradley's particular concern in the cited material involves the court's interpretation of treaty law, but his concerns regarding the domestic effect of the court's decisions may apply equally to its application of customary international law.

118. In the wake of the ICJ's decision in Military and Paramilitary Activities in and Against Nicaragua (Nicar. v. U.S.), 1986 I.C.J. at 108-109, the United States withdrew its consent to compulsory jurisdiction. See Letter from George P. Schultz, Secretary of State of the United States of America, to Javier Perez de Cuellar, Secretary-General of the United Nations (Oct. 7, 1985), in 24 I.L.M. 1742 (1985). There are other bases for the court to exercise jurisdiction over the United States, but each requires a separate means of consent-either to jurisdiction in a particular case, or to treaty terms conferring jurisdiction over a class of cases. See generally ICJ Statute, supra note 111, art. 36, 59 Stat. at 1060, 3 Bevans at 1186-87. Judgments rendered by the court in cases not involving the United States are not binding upon it. See infra text accompanying note 132 (discussing role of precedent in international tribunals).

119. See Bradley, International Delegations, supra note 3, at 1578-79. Before the United States formally provided notice that it was withdrawing its signature, it was obliged to respect the Rome Treaty's object and purposes, arguably raising delegation issues for unsigning. See generally Edward T. Swaine, Unsigning, 55 Stan. L. Rev. 2061 (2003) [hereinafter Swaine, Unsigning] (discussing controversy).

120. North American Free Trade Agreement, Dec. 8, 1992, ch. 11, § B, 32 I.L.M. 289, 642-47 [hereinafter NAFTA].

121. This includes interpreting whether national measures are "tantamount to nationalization or expropriation," "for a public purpose," "nondiscriminatory," and "in accordance with due process." NAFTA, supra note 120, art. 1110(1), 32 I.L.M. at 641. 
portedly constrained by preexisting customary international law, ${ }^{122}$ but that law, in fact, remains unclear. ${ }^{123}$ The panels also assess whether national measures accord with minimum standards required by international law-including, but not limited to, "fair and equitable treatment and full protection and security." ${ }^{24}$ Concerned about the discretion this vests in arbitrators, ${ }^{125}$ the state parties adopted Notes of Interpretation seeking to construe "international law" solely as "customary international law," seemingly reinforcing the panels' estrangement from treaties and other constitutionally orthodox processes for lawmaking. ${ }^{126}$ These Notes do not, in any event, resolve many issues of construction, ${ }^{127}$ and them-

122. The alternative, pressed by some NAFTA claimants, is that the treaty creates a lex specialis that sets a lower bar for expropriation claims. The United States, Mexico, and Canada have argued to the contrary, and their view has been endorsed by two tribunals. S.D. Myers, Inc. v. Canada, Partial Award, II 286, 40 I.L.M. 1408, 1440 (NAFTA Trib. 2000); Pope \& Talbot, Inc. v. Canada, Interim Award, II 104 (NAFTA Trib. 2000), available at http://www.dfait-maeci.gc.ca/tna-nac/documents/pubdoc7.pdf (on file with the Columbia Law Review).

123. Vicki Been \& Joel C. Beauvais, The Global Fifth Amendment? NAFTA's Investment Protections and the Misguided Quest for an International "Regulatory Takings" Doctrine, 78 N.Y.U. L. Rev. 30, 51-59 (2003); see also Joel C. Beauvais, Regulatory Expropriations Under NAFTA: Emerging Principles and Lingering Doubts, 10 N.Y.U. Envtl. L.J. 245, 257-58 (2002) (describing vagueness of expropriation standards under international law); id. at 266-77 (reviewing initial Chapter 11 cases).

124. NAFTA, supra note 120, art. 1105, 32 I.L.M. at 639; see id. art. 1110(1), 32 I.L.M. at 641 (incorporating, for purposes of expropriation standard, standard of Article $1105(1))$.

125. The particular impetus for this concern was a decision taking an expansive view of the potential of Article 1105. Pope \& Talbot, Inc. v. Canada, Award on the Merits of Phase 2, II 111, 118 (NAFTA Trib. 2001), available at http://www.dfait-maeci.gc.ca/tnanac/documents/Award_Merits-e.pdf (on file with the Columbia Law Review) (interpreting "fair and equitable treatment" in Article 1105(1) as adding to the minimum standard of treatment in customary international law, so as to "require that covered investors and investments receive the benefits of the fairness elements under ordinary standards applied in the NAFTA countries"); see Beauvais, supra note 123, at $272 \&$ n.127 (describing reaction to arbitrators' decision); Charles H. Brower, II, Structure, Legitimacy, and NAFTA's Investment Chapter, 36 Vand. J. Transnat'l L. 37, 47-48 (2003) [hereinafter Brower, Structure] (describing adoption of Notes of Interpretation as part of reaction to defeats suffered by Canada and Mexico).

126. NAFTA Free Trade Comm'n, Notes of Interpretation of Certain Chapter 11 Provisions, July 31, 2001, available at http://www.dfait-maeci.gc.ca/tna-nac/NAFTAInterpr-en.asp (on file with the Columbia Law Review). Section B of the Notes provides:

1. Article 1105(1) prescribes the customary international law minimum standard of treatment of aliens as the minimum standard of treatment to be afforded to investments of investors of another Party.

2. The concepts of "fair and equitable treatment" and "full protection and security" do not require treatment in addition to or beyond that which is required by the customary international law minimum standard of treatment of aliens.

3. A determination that there has been a breach of another provision of the NAFTA, or of a separate international agreement, does not establish that there has been a breach of Article 1105(1).

127. Charles H. Brower, II, Fair and Equitable Treatment Under NAFTA's Investment Chapter, 96 Am. Soc'y Int'l L. Proc. 9, 10-11 (2002) (suggesting that Notes are consistent 
selves occupy a peculiar middle ground between interpretation and law creation-thus running the (slight) risk that they will be disregarded by the tribunals. ${ }^{128}$

Assuming, then, that Congress is sufficiently implicated in these enterprises, the question remains whether they really involve the delegation of legislative authority. Those international institutions generating evidence of customary international law, like the General Assembly, typically leave the inference of legal authority to others; those institutions directly charged with making such inferences, like the NAFTA tribunals, seem to be judging rather than legislating. If assigning responsibility to federal courts to interpret and apply domestic law does not violate the nondelegation doctrine, ${ }^{129}$ how does customary international law?

To many, the distinction lies in the relatively indeterminate character of customary international law: Those assigned to construe it have so many sources from which to draw, and so few constraints, that the task of discovery and application is hard to distinguish from lawmaking. ${ }^{130}$ The

with view that bilateral investment treaties established opinio juris, or that treaty violations were evidence of unfair and inequitable treatment); Brower, Structure, supra note 125, at 78-80 (same).

128. The Free Trade Commission is authorized to issue interpretations of NAFTA that bind Chapter 11 tribunals, see NAFTA, supra note 120, art. 1131(2), 32 I.L.M. at 645, but amendments are supposed to be adopted by the ordinary legal processes particular to each party, id. art. 2202, 32 I.L.M. at 702. Some suggest that the Notes are less of an interpretation than a treaty modification, and are thus ultra vires. Guillermo Aguilar Alvarez \& William W. Park, The New Face of Investment Arbitration: NAFTA Chapter 11, 28 Yale J. Int'l L. 365, 397-98 (2003); Brower, Structure, supra note 125, at 49-50; see also id. at 79-82 (describing illegitimacy of Commission's adoption of Notes). If so, one arbitral award arguably implies, panels are free to ignore the Notes. See Pope \& Talbot, Inc. v. Canada, Award in Respect of Damages, II 47, 41 I.L.M. 1347, 1356 (NAFTA Trib. 2002) (indicating that "were the Tribunal required to make a determination whether the Commission's action is an interpretation or an amendment, it would choose the latter," but adding that it was not required to do so, and would assume that the Notes were merely an interpretation). But see Brower, Structure, supra note 125, at 48-49 (noting invocation of Notes by parties, and even retroactive application by one tribunal).

129. See Harold J. Krent, Delegation and its Discontents, 94 Colum. L. Rev. 710, 741 n.132 (1994) (book review) (noting that "the Supreme Court has never applied the nondelegation doctrine to judicial lawmaking”).

130. For elaborations of this claim, see David P. Fidler, Challenging the Classical Concept of Custom: Perspectives on the Future of Customary International Law, 39 German Y.B. Int'l L. 198 (1996); Jack L. Goldsmith \& Eric A. Posner, A Theory of Customary International Law, 66 U. Chi. L. Rev. 1113 (1999) [hereinafter Goldsmith \& Posner, Theory of Customary International Law]; Jack L. Goldsmith \& Eric A. Posner, Understanding the Resemblance Between Modern and Traditional Customary International Law, 40 Va. J. Int'l L. 639 (2000); J. Patrick Kelly, The Twilight of Customary International Law, 40 Va. J. Int'l L. 449 (2000). While a similar charge of indeterminacy is often made against international law in general, most critics take the view that customary international law is far more suspect than are international agreements. See, e.g., Jack L. Goldsmith \& Eric A. Posner, International Agreements: A Rational Choice Approach, 44 Va. J. Int'1 L. 113, 129 (2003) ("One reason why codification of customary international law occurs is that such law is often vague and contestable.”); John O. McGinnis, The Appropriate Hierarchy of Global Multilateralism and Customary International Law: The 
problem stems from the fact that statutory assignments to apply customary international law are, ultimately, delegations to a diffuse and amorphous international institution-the collective will and legal opinion of nation states. ${ }^{131}$ This underlying delegation also undermines any attempt by international or domestic courts to assert authority. While the decision of an international court construing customary international law binds the parties in the instant dispute, it does not establish binding precedent for future cases-reflecting, in part, the ad hoc, preinstitutional tradition of international proceedings. ${ }^{132}$ National courts, while enjoying greater permanence and independence, are little better situated: As with international tribunals, the real question concerns the practice and opinio juris of states, not the prior gloss given by courts. ${ }^{133}$ The result is

Example of the WTO, 44 Va. J. Int'l L. 229, 233 (2003) [hereinafter McGinnis, Appropriate Hierarchy] ("Multilateral agreements are likely to produce more legitimate and beneficent norms than customary international law. The process of discovering customary international law is fraught with difficulty and uncertainty and tends to result in principles with vague and uncertain contours.”).

131. The United States Court of Appeals for the Second Circuit, which was responsible for reviving the relevance of customary international law in U.S. courts, explained in 2003:

The determination of what offenses violate customary international law . . . is no simple task. Customary international law is discerned from myriad decisions made in numerous and varied international and domestic arenas. Furthermore, the relevant evidence of customary international law is widely dispersed and generally unfamiliar to lawyers and judges. These difficulties are compounded by the fact that customary international law-as the term itself implies-is created by the general customs and practices of nations and therefore does not stem from any single, definitive, readily-identifiable source. All of these characteristics give the body of customary international law a "soft, indeterminate character" that is subject to creative interpretation.

Flores v. S. Peru Copper Corp., 343 F.3d 140, 154 (2d Cir. 2003) (internal citations omitted) (quoting Louis Henkin, International Law: Politics and Values 29 (1995)); cf. Phillip R. Trimble, A Revisionist View of Customary International Law, 33 UCLA L. Rev. $665,720-23$ (1986) (finding that, to the extent that customary international law is derived from sources outside the United States, such as foreign governments, "it has no basis in popular sovereignty at all" and so "cannot be reconciled with American political philosophy").

132. Restatement of the Law (Third) of the Foreign Relations Law of the United States $\$ 103 \mathrm{cmt}$. b (1987) (recalling the "traditional view that there is no stare decisis in international law”); Jenny S. Martinez, Towards an International Judicial System, 56 Stan. L. Rev. 429, 482 (2003) (observing that "even within a single international court there is often no system of binding precedent and no doctrine of stare decisis," and concluding that " $[\mathrm{t}]$ he refusal to treat precedents as binding is a long-entrenched practice in international adjudication that stems from the origins of the international judicial system in the ad hoc arbitral courts of the nineteenth century"); e.g., ICJ Statute, supra note 111, art. 59, 59 Stat. at 1062, 3 Bevans at 1190 ("The decision of the Court has no binding force except between the parties and in respect of that particular case."). In practice, international courts do not entirely disregard their own past decisions. See Martinez, supra, at 483-84.

133. ICJ Statute, supra note 111, art. 38(1)(d), 59 Stat. at 1060, 3 Bevans at 1187 (identifying "judicial decisions . . . as subsidiary means for the determination of rules of law"); cf. Restatement of the Law (Third) of Foreign Relations Law of the United States 
that attempts to reckon the customary international law applicable in any given case appear less constrained by prior judgments and more akin to lawmaking, perhaps even by comparison to the common law. ${ }^{134}$

Delegation principles help illuminate the controversy over the Alien Tort Statute (ATS), which provides district courts with original jurisdiction over civil actions by aliens for torts "committed in violation of the law of nations or a treaty of the United States."135 Lower courts construed this language as creating a cause of action (as opposed to merely conferring jurisdiction) to enforce customary international law as it has evolved

$\S 102$ (2) (describing nature of customary international law); id. $\S 103$ (2) (describing sources of international law). According to the Restatement, international law determinations by domestic courts simply follow the same hierarchical principles appropriate to any other issues of law: Lower courts follow higher courts, and all U.S. courts follow the Supreme Court. Id. $\$ \S 103 \mathrm{cmt}$. b, 112(2) \& cmt. a. This appraisal is difficult to reconcile, however, with the evidentiary weight to be accorded the views of foreign courts and the executive branch, see id. $\S 112 \mathrm{cmts}$. b, c, as well as the "particular attention" accorded the views of international tribunals, see id. $§ 112(1)$.

Whether or not custom's external nature is fully respected in practice, the failure to do so may give rise to its violation, as adherence to local precedent creates a potential gap with international developments. Cf. Trendtex Trading Corp. v. Cent. Bank of Nig., 1977 Q.B. 529, 553-54 (Eng. C.A.) (Lord Denning) (explaining why doctrine of incorporation, reflecting developments in international law, should be preferred to doctrine of transformation, which instead privileges stare decisis). The risk of such a gap is greatest, it may be predicted, in the most dynamic areas-those in which the most customary international law is being made. See Francesco Francioni, International Law as a Common Language for National Courts, 36 Tex. Int'l L.J. 587, 588 (2001) (contending that, in cases of evolving customary international law, decisions of national courts cannot "simply reflect precedents in national law relevant to the dispute," lest they "perpetuat[e] . . . misconceived ideas of customary law or . . . unwarranted unilateral interpretation of the law" inconsistent with the international determination of the relevant norms).

134. See Been \& Beauvais, supra note 123, at 55 \& n.117 (distinguishing decisionmaking by arbitral panels from common law development, "insofar as the tribunals are not bound by stare decisis and are not subject to centralized appellate review . . . [and t] here is, as a result, no guarantee that delegation. . . . to adjudicative development will result in anything approaching uniform standards"); McGinnis, Appropriate Hierarchy, supra note 130, at 247-49 (suggesting that, by comparison to common law, customary international law is inefficient, lacks accountable decisionmaking, and suffers from relative lack of tradition and deliberative rationality); see also Swaine, Global Antitrust, supra note 92, at 715 n.355 (suggesting that the position of federal courts in applying customary international law may be likened to their role in applying state common law in diversity cases, but without any analog to state supreme courts on which they might depend). But cf. Henkin, Foreign Affairs, supra note 15, at 137 n.* (arguing that, relative to common law, "judges have been substantially less free to follow their own bent in determining customary international law, in view of the authority of the Executive branch in the matter and the need to attend to the practices and opinions of many nation-states over many years"). Tellingly, one federal judge recently extolled the relative stability and restraint of federal common law as compared to customary international law. Doe v. Unocal, No. 0056603, 2002 WL 31063976, at *28 (9th Cir. Sept. 18, 2002) (Reinhardt, J., concurring) (arguing in favor of employing federal common law for determining third-party liability), reh'g en banc granted, opinion vacated, No. 00-56603, 2003 WL 359787, at *1 (9th Cir. Feb. 14, 2003).

135. 28 U.S.C. $\$ 1350(2000)$. 
(rather than as that law existed in 1789, when the ATS was enacted). ${ }^{136}$ The Supreme Court's decision in Sosa v. Alvarez-Machain engineered a compromise, holding that while the first Congress did not intend to create a new cause of action, ${ }^{137}$ it anticipated both that courts would entertain torts then recognized under the common law and that they would come to recognize others. ${ }^{138}$ Under this reading, Congress has assigned to the federal courts modest authority to reckon customary international law, ${ }^{139}$ rather than employing its own legislative power-including its more specific authority to "define and punish . . . Offences against the Law of Nations" 140 _ to establish federal law. ${ }^{141}$ In doing so, it indirectly

136. The seminal case is Filartiga v. Pena-Irala, 630 F.2d 876 (2d Cir. 1980); see Flores v. S. Peru Copper Corp., 343 F.3d 140, 149-50 (2d Cir. 2003) ("[T] he Filartiga Court not only held that [Section 1350] provides a jurisdictional basis for suit, but also recognized the existence of a private right of action for aliens only seeking to remedy violations of customary international law or of a treaty of the United States.”).

137. 159 L. Ed. 2d 718, 748-49 (2004); see also id. at 751 (representing that "[a]ll Members of the Court agree that $\$ 1350$ is only jurisdictional”).

138. Id. at 752-53. The Court described the paradigms it specifically addressedpiracy, violation of safe conducts, and infringement of the rights of ambassadors-as the "principal offenses against the law of nations" that would have been evident to the first Congress, rather than an exhaustive list. Id. at 748-49. The Court found, moreover, that the first Congress intended to assign responsibility for "identify[ing] some international norms as enforceable" and that subsequent Congresses had not truncated that authority. Id. at 752-53.

139. Id. at 749 (holding that courts "should require any claim based on the presentday law of nations to rest on a norm of international character accepted by the civilized world and defined with a specificity comparable to the features of the 18th-century paradigms"). The Court's opinion emphasized modern, pragmatic reasons for limiting the courts' assignment under the ATS, including a changed conception of the common law (and the role of federal courts in generating it), a general preference for legislative creation of private rights of action, respect for the primacy of the political branches in foreign affairs, and the lack of any "congressional mandate to seek out and define new and debatable violations of the law of nations." Id. at 751. At the same time, it signaled that its approach was consistent with the limits previously established by many lower court decisions-including Filartiga, the case on which the more expansive modern approach is based. Id. at 752-53.

140. U.S. Const. art. I, § 8, cl. 10. Beth Stephens, in an important defense of the place of international law in U.S. law, holds out the Offenses Clause as the basis for the Alien Tort Claims Act (ATCA), but puts far more emphasis on its function in "punishing" offenses-and essentially admits that the power to "define" such offenses was delegated. Beth Stephens, Federalism and Foreign Affairs: Congress's Power To "Define And Punish . . Offenses Against the Law of Nations," 42 Wm. \& Mary L. Rev. 447, 523 (2000) ("Under the Clause, Congress has the power to 'define and punish' violations of the law of nations. It did so in the ATCA by creating a civil cause of action for such violations, leaving the definition of the offenses to the courts."); see also Brief for the United States as Respondent Supporting Petitioner at 32-36, Sosa (No. 03-339) (describing assertion of private rights of action under the ATCA as usurping Congress's define-and-punish authority).

141. By so privileging the place of international law in U.S. courts, one might argue, Congress has also delegated some of the relevant authority to the executive branch, given its greater significance in contributing to the underlying establishment of customary international law norms. See Ku, supra note 15, at 81 (describing President as holding 
enabled lawmaking by the international institutions and foreign nations ultimately responsible for contributing to state practice and opinio juris. ${ }^{142}$

\section{E. Other Delegation Issues}

In discussing delegations of legislative authority, I ignore other procedural objections stemming from Article $\mathrm{I},{ }^{143}$ as well as any potential distinctions between the use of congressional-executive agreements and the Article II treaty power. ${ }^{144}$ But two other, ostensibly more distinct,

"primary constitutional authority" over making of customary international law); Young, Trouble, supra note 3, at 534 (noting that because the Executive "tend[s] to be in charge of the international practice from which customary norms are derived," authority over lawmaking "shifts ... from the legislature to the executive").

142. Cf. Sosa, 159 L. Ed. 2d at 764 (Scalia, J., concurring) (criticizing "notion that a law of nations, redefined to mean the consensus of states on any subject," could be invoked to constrain U.S. sovereignty, and citing congressionally enacted legislation as the proper "method for making the laws that are over us").

143. For example, if an international institution exercises legislative authority, it is unlikely to comply with bicameralism and presentment requirements, see U.S. Const. art. I, $\$ 7$, cl. 2 (describing procedure for adopting legislation), and individuals involved in that exercise are unlikely to satisfy provisions governing the selection of senators and representatives, id. art. I, $\S 2$, cl. 2 (defining eligibility for election as Representative); id. art. I, § 3, cl. 3 (defining eligibility for election as Senator). See generally Bradley, International Delegations, supra note 3, at 1562 (describing procedural limits on delegation). Such offenses are thus highly congruent with legislative delegation problems. Put differently, delegations deemed to confer lawmaking authority would almost invariably offend the Constitution in these other respects. See supra note 97 (citing additional substantive objections under Article I).

144. See U.S. Const. art. II, $\S 2$, cl. 2. In the main, this simplification is defensible. Regardless of the initial lawmaking's form, some legislative principal has ceded authority, and the virtual interchangeability of treaties and congressional-executive agreements means that the interposition of international lawmaking displaces both Congress's legislative authority and the Senate's treaty power-and it makes little sense to consider constitutional offenses particular to Article II if that route need not be employed at all. See Restatement of the Law (Third) of the Foreign Relations Law of the United States $\$ 303$ \& cmt. e (1987) (asserting that "any agreement concluded as a CongressionalExecutive agreement could also be concluded by treaty," and that "[t]he prevailing view is that the Congressional-Executive agreement can be used as an alternative to the treaty method in every instance").

In practice, though, treaties are likely to be preferred in certain contexts. See CRS, supra note 75, at 26, 233-35 (describing criteria developed by the State Department, and consultations between Congress and the executive branch, regarding the occasions for employing treaties); id. at 178-81 (noting that, on occasion, the Senate has asserted responsibility for amendments to treaties and appeared to reject as inadequate involvement by the Congress as a whole). It may also be appropriate, therefore, to consider claimed infringements on the Senate's advice-and-consent function, at least if that function is more robust than its legislative alternative. See, e.g., Howard R. Sklamberg, The Meaning of "Advice and Consent": The Senate's Constitutional Role in Treatymaking, 18 Mich. J. Int'l L. 445 (1997) (comparing "Senatorial Dominance" model of treaty power with its alternatives). But see CRS, supra note 75, at 15-16, 79-80, 98-111 (noting examples of comparably broad assertions of congressional authority for involvement in negotiations). 
kinds of delegation merit brief mention. One set of issues is raised by the participation of foreign or international officials in the law's execution, arguably in violation of the Appointments Clause. ${ }^{145}$ The specter of executive delegation has been cast, for example, over NAFTA's Chapter $19^{146}$ and Chapter 11 arbitrations ${ }^{147}$ and the Technical Secretariat of the Or-

Finally, to the extent that international institutions exercise authority available to the President, they cannot be so readily said to entail a delegation of legislative authority. For example, a student note defends relying on the President to exercise a veto on behalf of the United States in international institutions by positing that "[i]n constitutional terms, treaties authorizing [such] procedures are essentially treaties authorizing subsequent executive agreements," melded with the President's independent authority to adopt executive agreements "interpreting a treaty." See Note, supra note 15, at 1101. It is debatable whether such treaties do in fact "explicitly authorize subsequent executive agreements," and whether the President is genuinely exercising "interpretive authority." Id. For its part, the Senate often defers, but sometimes asks that the Senate Foreign Relations Committee be kept informed of proposed amendments, and it is unresolved whether such supervision is adequate to discharge the Senate's treaty duties-which suggests that at least a modicum of legislative authority may remain at issue. CRS, supra note 75 , at $181-83$.

145. Bradley, International Delegations, supra note 3, at 1563 \& n.28. That clause governs "any appointee exercising significant authority pursuant to the laws of the United States” and thus properly deemed an “'Officer of the United States.'” Buckley v. Valeo, 424 U.S. 1, 126 (1976) (quoting U.S. Const. art. II, § 2). According to the Supreme Court, only the President and appointed officers-or, exceptionally, inferior officers authorized by Congress to be appointed by courts, or heads of departments-are to "administer the laws enacted by Congress," thus prohibiting legislative attempts to assign such tasks to others. Printz v. United States, 521 U.S. 898, 922 (1997). It is unclear whether the Appointments Clause framework properly applies to instances where the individuals are not employees of the federal government, or whether the necessary quantum of federal authority is being exercised by individuals principally engaged in enforcing international rather than federal law. For a careful discussion in the context of the Chemical Weapons Convention, see Yoo, New Sovereignty, supra note 15, at 120-29; see also Ku, supra note 15, at 107-10 (describing conflict between unfettered inspections mandated by Chemical Weapons Convention and accountability required by Appointments Clause). Other, more specific executive authority may also be implicated, such as the Commander-in-Chief authority that would arguably be compromised were U.S. forces to fall under UN or NATO command. Bradley, International Delegations, supra note 3, at 1570 n.58 (collecting authorities).

146. NAFTA, supra note 120, arts. 1904-1905, Annexes 1901.2, 1903.2, 1904.13, 32 I.L.M. at 683-85, 687-88 (describing mechanisms for review of final antidumping and countervailing measure determinations, composition and authority of panels, and review of panel decisions); see also 19 U.S.C. $\$ 1516 \mathrm{a}(\mathrm{g})$ (2000) (detailing U.S. implementation); id. $\$ 1516 \mathrm{a}(\mathrm{g})(7)(\mathrm{A})$ (sharply limiting challenges to particular panel decisions). As Professor Bradley explains, while the panel decisions bind U.S. agencies, the panels will in all likelihood include members-potentially a majority-who will not be Article III judges nor subject to the Article II appointment process. Bradley, International Delegations, supra note 3 , at 1575; see id. at $1575 \mathrm{n} .87$ (citing authorities); Ku, supra note 15, at 111-12 ("[R] emoval [to a NAFTA panel] eliminates any possibility of further review by an Article III court.”).

147. See Bradley, International Delegations, supra note 3, at 1576; supra text accompanying notes 120-128. These panels, which may award damages but not injunctive relief, are composed of private parties, so they would clearly fail any constitutional 
ganization for the Prohibition of Chemical Weapons. ${ }^{148}$ As these examples suggest, the constitutionality of such arrangements is often at least partly dependent on the standing of international legislative delegations, insofar as they determine the law the foreign or international officials are involved in discharging. ${ }^{149}$

A second set of issues concerns asserted diversions of "[t]he judicial Power of the United States" 150 to foreign and international officials. ${ }^{151}$ Such claims must confront the longstanding practice of employing international arbitral tribunals, ${ }^{152}$ which appear to have been controversial more because of their sometimes legislative character than due to any distinct Article III issue. ${ }^{153}$ Indeed, the difficulty in discriminating be-

standard if nondelegable executive authority were involved. See Bradley, International Delegations, supra note 3 , at 1576 .

148. See Convention on the Prohibition of the Development, Production, Stockpiling and Use of Chemical Weapons and on Their Destruction, Jan. 13, 1993, art. VIII, S. Treaty Doc. No. 103-21, at 42-57, 1974 U.N.T.S. 317, 332-41 (describing inspections of property by Organization and Secretariat); Bradley, International Delegations, supra note 3, at 1578; Kinkopf, supra note 15, at 392-95; Yoo, New Sovereignty, supra note 15, at 114-16.

149. Any distinctive objections to the assignment of executive authority are more likely to be raised than are concerns about legislative delegations-which, after all, indirectly confer authority on the executive branch in its diplomatic capacity-and thus raise fewer concerns about underenforcement. See, e.g., supra text accompanying note 101 (describing delegation controversy involving POPs treaties, in which executive branch has emphasized invasion of executive prerogatives); cf. The Constitutional Separation of Powers Between the President and Congress, supra note 105, at 18-25 (defending antiaggrandizement approach to separation of powers issues); John F. Manning, Textualism as a Nondelegation Doctrine, 97 Colum. L. Rev. 673, 710-25 (1997) [hereinafter Manning, Textualism] (distinguishing legislative self-delegations, through use of legislative history, from executory delegations to agencies and courts, on the ground that institutional incentives make self-delegation more likely and more dangerous).

150. U.S. Const. art. III, $\$ 1$.

151. See Bradley, International Delegations, supra note 3, at 1564-66. The relevant jurisprudence is abstruse. See, e.g., N. Pipeline Constr. Co. v. Marathon Pipeline Co., 458 U.S. 50, 90 (1982) (Rehnquist, J., concurring in judgment) (commenting on "frequently arcane distinctions and confusing precedents" in Article III jurisprudence).

152. See Quincy Wright, The Control of American Foreign Relations 116 (1922) (noting that there is no "encroachment upon the judicial power when treaties vest judicial powers in bodies other than [U.S.] courts," since such bodies do not exercise "the judicial power of the United States" and, in addition, may have more of a ministerial than judicial character); see also Golove, supra note 15, at 1744-46 (describing preconstitutional understanding of delegations to international tribunals, and legitimacy under present constitutional analysis). This distinct treatment is endorsed even by some of the most zealous critics of international delegations. See, e.g., The American Land Sovereignty Protection Act: Hearing on H.R. 883 Before the House Comm. on Resources, 106th Cong. (1999) (statement of Jeremy Rabkin, Professor, Cornell University), available at $1999 \mathrm{WL}$ 161089 , at *8 (noting that " [d] espite the traditional strictures against delegating U.S. treaty making authority to international bodies, there has always been an exception for judicial authorities").

153. The most significant instance involves the general arbitration treaties with France and Great Britain. General Arbitration Treaty between the United States of America and the French Republic, Aug. 3, 1911, U.S.-Fr., 4 Unperfected Treaties of the United States of America, 1776-1976, at 217-23 (Christian L. Wiktor ed., 1979); General 
tween international institutions exercising judicial power and those exercising legislative power is a continuing concern, ${ }^{154}$ and one directly germane here. While legislative delegations are faulted largely because they diminish political accountability, ${ }^{155}$ judicial delegations are frowned upon because they enhance political accountability for activities that should be assigned to separate, independent Article III jurists. ${ }^{156}$ The difficulty in distinguishing between legislative and judicial assignments, and the conflicting objections to them, hint at the need for care in the normative assessment of legislative delegations and for caution in establishing any inflexible rules as to their constitutionality.

$$
* * *
$$

The ubiquity of delegation issues should not be read to suggest that they go unremarked: The lesson, rather, lies in their persistence. A case in point is the Law of the Sea Convention. ${ }^{157}$ When President Reagan concluded that the deep seabed regime described by Part XI of the 1982 Convention was unacceptable, he cited, inter alia, the need for decisionmaking rules to protect the interests of participating states, and for a treaty that "will not allow for amendments to come into force without approval of the participating states, including in our case the advice and

Arbitration Treaty Between Great Britain and the United States, Aug. 3, 1911, U.S.-Gr. Brit., 4 Unperfected Treaties, supra, at 225-31. After the Senate attached amendments to its advice and consent, President Taft refused to ratify them, rejecting as "untenable" the view of the Senators that permitting an arbitral panel to determine whether it had jurisdiction over a particular dispute "would be an invalid delegation of the function of the Senate.” 5 Green Haywood Hackworth, Digest of International Law 67-68 (1943) (quoting William Howard Taft, The Presidency 102-04 (1916)); see also Chandler P. Anderson, The Senate and Obligatory Arbitration Treaties, 26 Am. J. Int'l L. 328, 331-32 (1932) (describing controversy).

154. See, e.g., Cesare P.R. Romano, The Proliferation of International Judicial Bodies: The Pieces of the Puzzle, 31 N.Y.U. J. Int'l L. \& Pol. 709, 714-19 (1999) (noting difficulty of classifying as judicial the International Criminal Tribunal for the Former Yugoslavia, the International Criminal Tribunal for Rwanda, and the WTO's dispute settlement bodies).

155. See infra note 171 and accompanying text.

156. See, e.g., Thomas v. Union Carbide Agric. Prods. Co., 473 U.S. 568, 582-83 (1985) (observing that Article III authority is designed to vest authority "in courts whose judges enjoy life tenure and fixed compensation," and that " $[\mathrm{t}]$ hese requirements protect the role of the independent judiciary within the constitutional scheme of tripartite government and assure impartial adjudication in federal courts"); see also Commodity Futures Trading Comm'n v. Schor, 478 U.S. 833, 850-51 (1986) (noting that Article III not only preserves litigants' interest in federal adjudication of claims, but also "safeguards the role of the Judicial Branch in our tripartite system by barring congressional attempts 'to transfer jurisdiction [to non-Article III tribunals] for the purpose of emasculating' constitutional courts" (quoting Nat'l Ins. Co. v. Tidewater Co., 337 U.S. 582, 644 (1949) (Vinson, C. J., dissenting))).

157. United Nations Convention on the Law of the Sea, opened for signature Dec. 10, 1982, 1833 U.N.T.S. 3 (entered into force on Nov. 16, 1994) [hereinafter LOS Convention]; see Agreement Relating to the Implementation of Part XI of the United Nations Convention on the Law of the Sea of 10 December 1982, July 28, 1994, 1836 U.N.T.S. 41 [hereinafter Part XI Agreement]. 
consent of the Senate."158 Renewed negotiations ultimately produced a supplementary agreement in 1994, and U.S. officials have since made ratification a priority, emphasizing improved sovereign control over the amendment process and other aspects of Convention governance. ${ }^{159}$

Despite these negotiating successes and other precautions, ${ }^{160}$ delegation issues remain. Even if the United States opted out of dispute settlement by the International Tribunal for the Law of the Sea or the International Court of Justice, it would still be subject to arbitral tribunals ${ }^{161}$ and, in some cases, to the Seabed Disputes Chamber. ${ }^{162}$ It would maintain a veto over formal amendments of the Convention, ${ }^{163}$ but continue to lack

158. Statement on United Nations Participation in the Third United Nations Conference on the Law of the Sea, 1982 Pub. Papers 92 (Jan. 29, 1982); accord Statement on the Withholding of United States Funds From the Law of the Sea Preparatory Commission, 1982 Pub. Papers 1652 (Dec. 30, 1982).

159. Letter of Submittal of the Secretary of State to the President of the United States, Sept. 23, 1994, reprinted in Message from the President of the United States and Commentary Accompanying the United Nations Convention on the Law of the Sea and the Agreement Relating to the Implementation of the Part XI Upon Their Transmittal to the United States Senate for its Advice and Consent, 7 Geo. Int'l Envtl. L. Rev. 77, 83 (1994) ("The [Part XI] Agreement guarantees a seat for the United States on the critical executive body and requires a consensus of major contributors for financial decisions."); id. ("A future decision, which the United States and a few of its allies can block, is required before the organization's potential operating arm (the Enterprise) may be activated, and any activities on its part are subject to the same requirements that apply to private mining companies."); Accession to the 1982 Law of the Sea Convention and Ratification of the 1994 Agreement Amending Part XI of the Law of the Sea Convention: Hearing Before the House Comm. on Int'l Relations, 108th Cong. (2004) (statement of the Honorable William H. Taft IV, Legal Advisor, U.S. Dep't of State) (emphasizing U.S. veto authority under Part XI agreement). See generally Bernard H. Oxman, The 1994 Agreement and the Convention, 88 Am. J. Int'l L. 687 (1994) (comparing official objections to the 1982 Convention with subsequent developments).

160. See S. Exec. Rep. No. 108-10 (2004), reprinted in 150 Cong. Rec. S2712 (daily ed. Mar. 11, 2004) (setting out terms of Senate advice and consent, including declarations and understandings, as approved by the Senate Committee on Foreign Relations).

161. Articles 287(1) and 298(1) of the LOS Convention permit members to select special arbitral panels for dispute resolution, in lieu of those courts, and the United States has expressed the intent to avail itself of that option. See S. Exec. Rep. No. 108-10, § 2, 150 Cong. Rec. at S2712.

162. The United States would avoid the Chamber to the extent possible. See id. But not all of the Chamber's authority may be circumvented, see LOS Convention, supra note 157, art. 187, Annex VI arts. 14, 36, 1833 U.N.T.S. at 475-76, 564, 569-70, and the Convention provides that its judgments are fully enforceable in the territories of state parties, id. Annex VI art. 39, 1833 U.N.T.S. at 570. The U.S. declaration on this point is begrudging, and its international effect is unclear. S. Exec. Rep. No. 108-10, § 3(22), 150 Cong. Rec. at S2713 (declaring that Chamber decisions "shall be enforceable in the territory of the United States only in accordance with procedures established by implementing legislation and . . . shall be subject to such legal and factual review as is constitutionally required and without precedential effect in any court of the United States").

163. The precise scope of the veto, and its ability to resolve President Reagan's concern about the Senate's prerogatives, is uncertain. Amendments relating to Part XI (that governing the seabed regime) require a consensus vote in the Council, LOS 
any true veto over most means by which the International Seabed Authority may promulgate binding rules and regulations. ${ }^{164}$ These issues are likely to play a continuing role in the Convention's domestic consideration. ${ }^{165}$

Convention, supra note 157 , art. $161(8)$ (d), 1833 U.N.T.S. at 462, and the United States is guaranteed a position on the Council by virtue of its economic standing when the Convention entered into force, Part XI Agreement, supra note 157, Annex § 3(15) (a), 1836 U.N.T.S. at 59. But these amendments then enter into force for every state one year after ratification or accession by three-fourths of the parties-that is, without any prerequisite of ratification. LOS Convention, supra note 157, art. 316(5), 1833 U.N.T.S. at 521. The Senate's provisional advice and consent terms would declare that U.S. ratification of amendments follows the normal treaty process. S. Exec. Rep. No. 108-10, $\S 4(\mathrm{a})(5), 150$ Cong. Rec. at S2713 (declaring that "[t]he United States . . . shall take all necessary steps under the Convention to ensure that amendments under article 316(5) are adopted in conformity with the treaty clause"); see also id. § 4(a) (1)-(3), 150 Cong. Rec. at S2713 (proposing presidential consultation with Senate Foreign Relations Committee). But that proviso may not apply to all amendments, see id. $\$ 4(\mathrm{a})(4), 150 \mathrm{Cong}$. Rec. at S2713 (proposing that all amendments "other than amendments under article 316(5) of a technical or administrative nature" be submitted for advice and consent), and its effect on the United States' international obligation to respect amendments that it has not so ratified is unclear.

164. General policies of this kind may be established by a two-thirds majority of state parties acting through the Assembly. Part XI Agreement, supra note 157, § 3(1), (3), 1836 U.N.T.S. at 57. The U.S. check exists by virtue of its position in the Council, which issues recommendations in its areas of competence that the Assembly must heed. Id. § 3(4), 1836 U.N.T.S. at 57; see also LOS Convention, supra note 157, art. 162(2), 1833 U.N.T.S. at 463-66 (noting, among others, Council competence for budget, finance, and seabed activities). Some Council decisions, however, require only a two-thirds majority, and may be blocked by a majority in any one of five "chambers" of member states. Part XI Agreement, supra note $157, \S 3(5), 1836$ U.N.T.S. at 57. The United States, as a presumptive member of one of the smaller Council chambers, may find it easier than most to block Council decisions. Id. $\$ \S 3(9)(a), 3(15), 1836$ U.N.T.S. at 58-59; Jonathan I. Charney, Entry Into Force of the 1982 Convention on the Law of the Sea, 35 Va. J. Int'l L. 381, 393-94 (1995); Oxman, supra note 159, at 689-90. But for matters not requiring a consensus, this is less secure than a veto, since the United States is powerless to oppose measures supported by a two-thirds majority of the Council and at least two of the four members of its chamber.

The U.S. position is more secure with respect to financial and budgetary matters. Decisions by the Assembly or Council "having financial or budgetary implications" must be based on recommendations by the Finance Committee. Part XI Agreement, supra note 157, §3(7), 1836 U.N.T.S. at 57; cf. id. \$9(7), 1836 U.N.T.S. at 65-66 (providing that decisions on a list of financial and budgetary matters "shall take into account" Finance Committee recommendations). Substantive Committee decisions must be taken by consensus, id. $\S 9(8), 1836$ U.N.T.S. at 66 , and the five largest contributors to the Authority's budget are guaranteed Committee membership until such point as the Authority is financially self-sufficient, id. $\$ 9(3), 1836$ U.N.T.S. at 65 . While this has been equated to a U.S. veto, e.g., U.S. Dep't of State, Oceans Policy and the Law of the Sea Convention, reprinted in Contemporary Practice of the United States Relating to International Law, 88 Am. J. Int'l L. 733, 738 (1994), it depends (for the foreseeable future) on maintaining U.S. contributions.

165. See, e.g., Steve Hirsch, Law of the Sea Treaty Getting Submerged, Nat'l J., Apr. 10, 2004, at 1126, 1126-27 (noting argument by treaty opponents that "the treaty would jeopardize U.S. sovereignty and surrender too much power to the United Nations and to 


\section{International Delegations and the Nondelegation Canon}

While international delegations are many and various, the hurdles awaiting any nondelegation objection are forbidding. Extending domestic doctrine to international circumstances may be problematic, and there is also the question of the domestic doctrine's vitality. As if this were not enough, recent scholarship has claimed that the doctrine is based on a conceptual error: Congressional allocations of authority to others constitute an exercise of legislative power, rather than a transfer of it, and thus have no implications for national welfare or democracy. That argument, as this Part details, is far less persuasive with regard to international delegations, which involve the surrender of congressional authority and the loss of ex post controls.

It does not follow, of course, that such delegations are unconstitutional, but only that they are worth evaluating as a distinctive legal phenomenon. Indeed, those insisting instead on heightening the salience of the nondelegation doctrine-reviving it, for example, as a basis for invalidating international agreements, as an interpretive canon, or by analogy to treaty non-self-execution-may be insufficiently sensitive to the differing character of international delegations, while slighting mundane reasons why the nondelegation doctrine has been unenforceable since its debut.

\section{A. The Apparent Relevance of the Nondelegation Doctrine}

Perhaps because it has so rarely been applied, the basics of the nondelegation doctrine are easily sketched. Article I of the Constitution vests "[a]ll legislative [p] owers herein granted" to the full Congress. ${ }^{166}$ On the premise that this vesting is exclusive, the nondelegation doctrine provides that "Congress generally cannot delegate its legislative power to another Branch," 167 or for that matter, to any other "entity,"168 such as a private party. ${ }^{169}$ The objective, according to the Supreme Court, is to

new international organizations envisioned under the convention," and citing predictions that opposition would prevent consideration of the Convention during 2004).

166. U.S. Const. art. I, § 1; see A.L.A. Schechter Poultry Corp. v. United States, 295 U.S. 495, 529 (1935) (interpreting constitutional grant of legislative power to Congress as exclusive); Pan. Ref. Co. v. Ryan, 293 U.S. 388, 421 (1935) (same). That these powers are vested in the full Congress, and thus seem different than the individual entitlement of members to vote, figures prominently in a recent defense of the nondelegation doctrine. See generally Larry Alexander \& Saikrishna Prakash, Reports of the Nondelegation Doctrine's Death Are Greatly Exaggerated, 70 U. Chi. L. Rev. 1297 (2003).

167. Mistretta v. United States, 488 U.S. 361, 372 (1989).

168. Loving v. United States, 517 U.S. 748, 758 (1996).

169. Carter v. Carter Coal Co., 298 U.S. 238, 310-11 (1936) (invalidating delegation to coal producers and miners party under Bituminous Coal Conservation Act, described as "legislative delegation in its most obnoxious form; for it is not even delegation to an official or an official body, presumptively disinterested, but to private persons whose interests may be and often are adverse to the interests of others in the same business"); Schechter Poultry, 295 U.S. at 537 (criticizing delegation to "trade or industrial associations or groups" in 
"ensure [ ] to the extent consistent with orderly governmental administration that important choices of social policy are made by Congress, the branch of our Government most responsive to the popular will."170 Reflecting the sense that delegation is unavoidable in modern government, but that Congress should be kept accountable, ${ }^{171}$ the Court has required Congress to establish an "intelligible principle" according to which the party vested with authority must conform. ${ }^{172}$

In the absence of any constitutional provisions addressing delegations to international institutions, ${ }^{173}$ the domestic doctrine provides us with the starting point for analysis, and even this brief account highlights arguments for taking international delegations less seriously than their domestic kin. The first would emphasize U.S. participation in any institution's decisionmaking process, which arguably leaves any delegation unconsummated. The nature of that process, of course, is of considerable significance. If U.S. preferences may be overridden-such as where delegated authority is exercised by an independent organ, like a tribunal, or by majority or qualified-majority voting among the members ${ }^{174}$ - the initial delegation remains highly salient. If the institution acts, a nondelega-

connection with National Recovery Act). But see George W. Liebmann, Delegation to Private Parties in American Constitutional Law, 50 Ind. L.J. 650, 664-65 (1975) (reading Carter v. Carter Coal as primarily concerning due process).

170. Indus. Union Dep't v. Am. Petroleum Inst., 448 U.S. 607, 685 (1980) (Rehnquist, J., concurring) (citing United States v. Robel, 389 U.S. 258, 276 (1967) (Brennan, J., concurring in result), and Arizona v. California, 373 U.S. 546, 626 (1963) (Harlan, J., dissenting in part)).

171. See Mistretta, 488 U.S. at 371-80 (1989); cf. Clinton v. City of New York, 524 U.S. 417, 490 (1998) (Breyer, J., dissenting) (noting, in discussing potentially problematic delegation, that the President, unlike agency officials, is directly responsible to electorate).

172. In J.W. Hampton, Jr., E Co. v. United States, Chief Justice Taft opined that "[i]n determining what [Congress] may do in seeking assistance from another branch, the extent and character of that assistance must be fixed according to common sense and the inherent necessities of the governmental co-ordination." 276 U.S. 394, 406 (1928). At least where "Congress shall lay down by legislative act an intelligible principle to which the person or body authorized to [exercise the delegated authority] is directed to conform, such legislative action is not a forbidden delegation of legislative power." Id. at 409; accord Whitman v. Am. Trucking Ass'ns, 531 U.S. 457, 472-76 (2001) (discussing "intelligible principle" standard and upholding statute instructing EPA to administer policy so as to "protect public health").

173. Compare, for example, the Dutch Constitution, which expressly permits allocating legislative, executive, and judicial functions to international organizations, see Jan Klabbers, An Introduction to International Institutional Law 205 (2002), with the Danish Constitution, which appears to incorporate an international nondelegation doctrine, permitting delegations but only if they are specified in particular detail, see Sten Harck \& Henrik Palmer Olsen, Decision Concerning the Maastricht Treaty, 93 Am. J. Int'l L. 209, 210-11 (1999) (summarizing Danish Supreme Court case discussing constitutional requirement of specificity). For surveys of such provisions, see Magdalena M. Martin Martinez, National Sovereignty and International Organizations 9-62 (1996); Antero Jyränki, Transferring Powers of a Nation-State to International Organisations: The Doctrine of Sovereignty Revisited, in National Constitutions in the Era of Integration 61 (Antero Jyränki ed., 1999).

174. See supra text accompanying notes $42-43$. 
tion issue is presented, regardless of whether the United States has actively opposed the initiative. ${ }^{175}$

Even the ability to exercise a veto is something less than a categorical distinction. ${ }^{176}$ The veto's potential decisiveness may be checked by countervailing interests-including the desire to avoid encouraging other nations to exercise their vetoes-and if waived is no more helpful than an ordinary vote. Its force may also be limited by the default condition. In some instances, vetoes act not to restore national discretion, but instead to maintain constraints on national sovereignty that came into being with the institution in question. ${ }^{177}$ In other instances, vetoes preserve the exercise of delegated authority by subordinate agents. ${ }^{178}$

The limited comfort afforded by veto authority is best illustrated by the Security Council's Chapter VII authority. The Charter generally bars the use of force, but also delegates to the Security Council power to au-

175. It is plausible, for example, that the United States would elect not to oppose an initiative against which it could not prevail. The same reasoning may be behind the principle that the President's failure to veto legislation does not waive separation of powers objections to it. See Consumer Energy Council of Am. v. FERC, 673 F.2d 425, 464 n.166 (D.C. Cir. 1982) (denying "that the President in any way waives his right to object to the legislative veto if he fails to veto it or if his veto is overridden"), aff'd sub. nom. Process Gas Consumers Group v. Consumer Energy Council of Am., 463 U.S. 1216 (1983) (noting instances in which "laws were held unconstitutional, because they trenched on the authority of the Executive Branch," notwithstanding the President's failure to exercise veto authority); see also Nat'l League of Cities v. Usery, 426 U.S. 833, 841 n.12 (1976) (“Judicial review of the constitutionality of legislative acts is independent of the presidential veto power. The Supreme Court has never hesitated to find an unconstitutional encroachment on presidential authority simply because the President signed the statute at issue."). Because Congress always possesses the power to override such a veto, see U.S. Const. art. I, $\$ 7$, cl. 2, there may be instances in which exercising a veto would simply forestall the inevitable, and insisting that it be so exercised could be counterproductive.

176. See supra text accompanying notes 42-44 (discussing relevance of unanimity to defining international legislation). But cf. Henkin, Foreign Affairs, supra note 15, at 254 (describing "probably a complete answer" to constitutional objections: "[T]he United States has a veto in the Security Council"); id. at 263 (responding to constitutional objections).

177. See infra text accompanying notes 179-181 (discussing Security Council). For example, in the U.S.-Russian Polar Bear Treaty, national representatives must concur before the U.S.-Russia Polar Bear Commission makes any decision establishing annual taking limits, which appear to be a prerequisite for most takings of polar bears from the governed population. Agreement Between the Government of the United States of America and the Government of the Russian Federation on the Conservation and Management of the Alaska-Chukotka Polar Bear Population, Oct. 16, 2000, U.S.-Russ, art. 5, S. Treaty Doc. No. 107-10 (banning any takings inconsistent with the Agreement); id. art. 6 (exempting certain takings by native people and for scientific research); id. art. 87 (assigning responsibility for establishing limits to Commission). To be sure, the discretion afforded national sovereigns was previously constrained. Agreement on the Conservation of Polar Bears, Nov. 15, 1973, 27 U.S.T. 3918, 13 I.L.M. 13 (binding United States, Norway, Denmark, Canada, and former Soviet Union).

178. See supra note 55 (explaining how DSB acts by consensus, but absent such consensus is deemed to have accepted arbitral panel and Appellate Body decisions). 
thorize it; ${ }^{179}$ as a Permanent Member, the United States may veto any proposed authorization, but by the very same token any of the other four Permanent Members may thwart a U.S. initiative. ${ }^{180}$ Once the Security Council has taken action, moreover, the failure to obtain unanimity among the Permanent Members operates as a "reverse veto" that preserves existing resolutions, including any with which the United States has come to disagree. ${ }^{181}$

The existence of a veto, finally, does little to redeem international delegations relative to their domestic kin. Even where completely effective, a veto simply substitutes executive branch officials, who exercise U.S. veto authority, for the international delegate-meaning that Congress still loses control. ${ }^{182}$ The mere fact that U.S. officials have endorsed the

179. Compare U.N. Charter art. 2, para. 4 (prohibiting "the threat or use of force against the territorial integrity or political independence of any state, or in any other manner inconsistent with the Purposes of the United Nations"), and id. art. 51 (exempting "the inherent right of individual or collective self-defence if an armed attack occurs against a Member of the United Nations, until the Security Council has taken measures necessary to maintain international peace and security"), with id. art. 42 (providing that Security Council, having determined existence of threat to "international peace and security," may take corrective military action), and id. art. 43 (requiring member states to assist in effectuating Security Council determinations).

180. Id. art. 27, para. 3. Joel Westra has noted that the veto, by checking centralized control, indirectly liberates an offsetting power of member "autointerpretation." Joel H. Westra, The UN Charter and Uses of Force by Major Powers: An Initial Assessment 6 (Apr. 18, 2004) (unpublished manuscript, on file with the Columbia Law Review). As he also observes, however, member states have an incentive to curb any extreme, self-serving interpretations, lest they diminish the incentive of other states to support the system. Id. at $6-7$.

181. See Caron, supra note 52, at 577-88. As an historical matter, this check has inured primarily, if not solely, to the benefit of the United States, which (together with the United Kingdom) used the threat of a reverse veto to prevent the lifting of sanctions on Iraq. See id.; Simon Chesterman \& Beatrice Pouligny, Are Sanctions Meant to Work? The Politics of Creating and Implementing Sanctions Through the United Nations, 9 Global Governance 503, 508-09 (2003). Some have also suggested that the problem may be passé, due to the new technique of placing time limits on sanctions. See Lutz Oette, A Decade of Sanctions Against Iraq: Never Again! The End of Unlimited Sanctions in the Recent Practice of the UN Security Council, 13 Eur. J. Int'l L. 93, 95-96 (2002). But that technique has not been universally exploited. Chesterman \& Pouligny, supra, at 509-10 (citing example of Resolution 1390 on Afghanistan, which provided only for " 'review[ ]" of financial sanctions and travel bans in twelve months, after which point the Security Council "'will either allow these measures to continue or decide to improve them'"-with the failure to act resulting, presumably, in Resolution's continuation (quoting S.C. Res. 1390, U.N. SCOR, 57th Sess., 4452d mtg., II 3, U.N. Doc. S/RES/1390 (2002))).

182. See Damrosch, Sovereignty, supra note 15, at 160 (responding to Louis Henkin's invocation of veto authority by noting concern about "activist use" of U.S. powers by the President). Congress does sometimes try to avoid this delegation reallocation problem by directing executive branch voting, but that has been bitterly resisted. See, e.g., Statement on Signing the Omnibus Consolidated and Emergency Supplemental Appropriations Act, 1999, 2 Pub. Papers 1847-48 (Oct. 23, 1998) (objecting to, and regarding as advisory only, statutory provisions requiring reporting to Congress prior to voting for UN peacekeeping missions, or directing the executive branch as to how to conduct negotiations with international organizations); Statement on Signing the FREEDOM Support Act, 2 Pub. 
exercise of the delegated authority by withholding the veto is not much different from the kind of acquiescence that the Congress and President invariably exhibit in domestic delegations-which, courts have suggested, should be irrelevant. ${ }^{183}$

A second argument for distinguishing international delegations, that the United States may always withdraw from its international obligations, ${ }^{184}$ overstates the ease of doing so. On the international plane, withdrawal is costly by design and infrequently done. ${ }^{185}$ That the United States may also override international delegations as a matter of domestic law seems particularly unconvincing. ${ }^{186}$ Congress equally possesses the

Papers 1973-74 (Oct. 24, 1992) (objecting to, and regarding as advisory only, "provisions purport[ing] to direct me or my delegates with respect to U.S. participation in international institutions"); Common Legislative Encroachments on Executive Branch Authority, 13 Op. Off. Legal Counsel 248, 257 (1989) ("No limitations on the President's authority to discuss certain issues with foreign governments, or to recommend or concur in courses of action taken by other nations, should be sanctioned.").

183. As noted earlier, an analogy between the President's legislative veto and a U.S. veto in some international institutions is not entirely apposite, since the President's veto may be overridden. See supra note 175 and accompanying text. But the Supreme Court has declined to endorse any waiver of constitutional claims even under circumstances in which an institution's objection would be decisive, as when the House has acquiesced in an Origination Clause violation. See United States v. Munoz-Flores, 495 U.S. 385, 397 (1990) ("A law passed in violation of the Origination Clause would thus be no more immune from judicial scrutiny because it was passed by both Houses and signed by the President than would a law passed in violation of the First Amendment.").

184. See Henkin, Foreign Affairs, supra note 15, at 262 ("Perhaps the fact that the United States retains the power to terminate its participation saves any otherwise questionable delegations.”); cf. Raustiala, Rethinking, supra note 12, at 846-47 (noting possibility of exiting international treaties or organizations as a check on compromised sovereignty).

185. Some treaties, like the agreement that established the WTO, make withdrawal relatively straightforward. WTO Agreement art. XV (establishing permission for withdrawal after six months notice). But treaties often fail to provide explicitly for a right to withdraw; barring express mention, there is no right to withdraw unless it can be established that the parties intended to permit withdrawal or that such a right may be implied by the nature of the treaty. See VCLT, supra note 65, art. 56(1), 1155 U.N.T.S. at 345. Even where withdrawal is permitted, as with the WTO, the regime may create such dependence as to make withdrawal nearly impossible. Compare Raustiala, Rethinking, supra note 12, at 847 (suggesting that "no one seriously thinks . . . that Japan or Canada cannot leave the [WTO] and thus retract whatever power they in essence delegated to that institution, though it may be costly to do so"), with Perez, supra note 55, at 38 (stressing impracticality of leaving the WTO). For further discussion, see infra text accompanying notes 293-297.

Similar problems attend attempts to withdraw from customary international law, at least on the international plane. The right of a nation to liberate itself by persistently objecting is limited to the period of custom's formation, and evaporates at that (uncertain) point when custom has been formed. Restatement of the Law (Third) of the Foreign Relations Law of the United States $\S 102 \mathrm{cmt}$. d (1987). Custom may be amended by another supervening custom or by treaties, id. $\S 102$ reporters' note 4 , but these are not options that a dissatisfied nation may independently pursue.

186. See, e.g., Golove, supra note 15, at 1741 (observing that, due to last-in-time rule, "Congress can simply supersede, as a matter of domestic law, a treaty, or a self-executing 
authority to reverse and override its prior domestic delegations. While there are significant impediments to revising domestic statutes, it is hard to say that it is categorically more difficult, and equally hard to conclude that the power to withdraw should uniquely disqualify international delegations. ${ }^{187}$

A third argument for distinguishing international delegations is not unrelated: the sense that they may generate international legal obligations for the United States, and constrain its government, but lack domestic legal effect equivalent to other delegations. 188 The point is a fair one, so far as it goes, ${ }^{189}$ but its significance for delegation analysis is unclear. Legislative authority exercised by virtue of international delegations-at least those not implemented by assimilative statutes-indeed lacks the legal consequences for private conduct that most domestic delegations might claim. ${ }^{190}$ But it is not clear why that should be a litmus test for

resolution of an international body made pursuant to a treaty, by enacting an inconsistent statute, and domestic courts will enforce Congress's later expressed will," so that "even when the resolutions of international bodies are made self-executing, they always remain subject to domestic revision by the political branches").

187. Cf. Bradley, International Delegations, supra note 3, at 1595 n.186 (disputing that non-self-execution solution is unnecessary in light of congressional power to override). One practical difference, I suppose, is that in purely domestic delegations to the executive branch, the delegate-in-chief may exercise a veto over any subsequent statute. But this has not been thought to warrant different treatment of domestic delegations to private parties or to the states. See supra note 169 and accompanying text (discussing delegation to private parties); infra text accompanying note 322 (discussing delegation to states). Moreover, the President certainly has a stake in international delegations as well, and equal access to the veto. See infra text accompanying notes 281-284 (discussing President's role in international delegations). Finally, Congress retains, of course, the authority to override any veto, and thus to retract any delegation, domestic or international, that may have been effected. See infra text accompanying note 272 (noting congressional authority to override veto).

188. See, e.g., Henkin, Foreign Affairs, supra note 15, at 263-65 (describing differences between U.S. international obligations and domestic law). I discuss below one solution to international delegations that would accentuate that difference. See infra text accompanying notes 250-259 (discussing non-self-execution approach).

189. How far it is in fact intended to go is somewhat obscure. Professor Henkin suggests, for example, that

$[a] n$ international regulation might impose obligations on the United States that might require changes in U.S. law, but it is the United States that will have to legislate to that end, whether it does so by giving legal effect directly to a selfexecuting treaty, or by act of Congress to implement the agreement.

Henkin, Foreign Affairs, supra note 15, at 264. What it means to "legislate to . . . giv[e] legal effect directly to a self-executing treaty" is unclear, where the dominant meaning of self-executing is to have legal effect "without awaiting any act by Congress," id. at 199, unless it is meant to connote something more like an act of will. In any event, Henkin elsewhere dismisses the significance of such niceties. See infra note 197.

190. Domestic delegations to nonfederal entities, again, may be more comparable: The delegation at issue in Carter v. Carter Coal Co., for example, merely authorized private parties to fix minimum wages that regulated parties might accept or reject (though, were the wage levels rejected, the regulated parties would be subject to other federal law). 298 U.S. 238, 310-11 (1936). 
delegations. ${ }^{191}$ International exercises of authority, even those without separate assimilation, still have direct, material consequences for U.S. citizens ${ }^{192}$-for example, for persons awarded damages by a NAFTA Chapter 11 arbitration, ${ }^{193}$ or for persons immunized from prosecution by Security Council Resolution 1422.194 Even where international law lacks direct effect, its domestic influence may be substantial: It is unlikely that Congress simply ignores the discontinuity between domestic and international law on many occasions, ${ }^{195}$ and more likely that the United States does what it is obligated to do. ${ }^{196}$

In any case, the fact that the United States remains obligated on the international plane to implement its obligations is of sufficient constitutional significance. ${ }^{197}$ There is room for dispute as to whether all international obligations require domestic implementation, ${ }^{198}$ and whether

191. The starting point, perhaps, is the insight that international exercises lacking domestic legal effect cannot be the precise equivalent of congressional lawmaking. Cf. Alf Ross, Delegation of Power, 7 Am. J. Comp. L. 1, 18 (1958) (contending that, for purposes of the doctrine delegata potestas non potest delegari, "[d]elegation of powers takes place when an authority ... authorizes another to issue regulations which the authority itself could have made, and having the same legal force as if made by the delegator himself"). The problem is that even the authority exercised under domestic delegations lacks equivalence. For example, where Congress has itself exercised its lawmaking authority, later enactments are presumed not to have repealed that exercise-but no equivalent presumption would be extended to executive branch exercises of delegated authority. Cf. Astoria Fed. Sav. \& Loan v. Solimino, 501 U.S. 104, 108-11 (1991) (distinguishing between clear statement rule applicable to implied repeals and presumption favoring administrative estoppel). The President, moreover, is at liberty to countermand exercises of delegated authority (at least within the limits of the delegation), but does not enjoy that authority where Congress has itself made the law.

192. Cf. Schoenbrod, supra note 9, at 181-85 (suggesting that lawmaking is distinguished by its creation of rules of conduct to affect expected behavior of individual citizens).

193. See supra text accompanying notes $120-128$.

194. See supra text accompanying note 87 .

195. See Young, Trouble, supra note 3, at 535. One clear signal in this regard is the number of assimilative statutes, which essentially implement international delegations on the home front. See supra Part I.C. But see Tushnet, Transnational/Domestic, supra note 15 , at 254 (arguing that the effects of international obligations on domestic political dynamics are uncertain and insufficient to frame constitutional issues).

196. See, e.g., Louis Henkin, How Nations Behave: Law and Foreign Policy 47 (2d ed. 1979) [hereinafter Henkin, How Nations Behave] ("It is probably the case that almost all nations observe almost all principles of international law and almost all of their obligations almost all of the time." (emphasis omitted)).

197. Henkin, Foreign Affairs, supra note 15, at 203 ("Whether a treaty is selfexecuting or not, it is legally binding on the United States. Whether it is self-executing or not, it is supreme law of the land."); id. (noting that while Chief Justice Marshall suggested that a non-self-executing agreement "is not 'a rule for the Court' [,] he did not suggest that it is not law for the President or for Congress" (quoting Foster v. Neilsen, 27 U.S. (2 Pet.) 253, $314(1829))$ ).

198. For example, there is disagreement as to whether the United States is legally bound to comply with WTO dispute settlement decisions-but substantial authority to the effect that they must. E.g., GATT Dispute Panel Report on United States Measures Affecting Alcoholic and Malt Beverages, June 19, 1992, GATT B.I.S.D. (39th Supp.) at 297 
and how the President and Congress may be constrained, ${ }^{199}$ but it is unnecessary to suppose the most stringent view on such questions. That the relevant actors may choose not to fulfill their legal obligations is also not decisive, since law may always be disregarded. ${ }^{200}$ While the courts have deferred a great deal to the political branches in foreign affairs, they have never declared each and every dispute about external matters to be a political question. ${ }^{201}$ In any case, the constitutional significance of even nonjusticiable questions of international legal authority seems beyond doubt. ${ }^{202}$ For these reasons, whether or not international law is truly "part of our law" for all intents and purposes, ${ }^{203}$ the existence of interna-

(1993) [hereinafter GATT Report on Alcoholic Beverages] ("GATT law is part of Federal law in the United States and as such is superior to GATT-inconsistent State law."); see John H. Jackson, International Law Status of WTO Dispute Settlement Reports: Obligation to Comply or Option to "Buy Out"?, 98 Am. J. Int'l L. 109 (2004) (describing controversy and arguing for legal obligation to comply).

199. See, e.g., Louis Henkin, International Law as Law in the United States, 82 Mich. L. Rev. 1555, 1568 (1984) (discussing obligations of President and Congress with respect to enforcing international obligations); see also Damrosch, Sovereignty, supra note 15, at 160-61 (describing and assessing position that "[t]he United States remains constitutionally free to disregard whatever legal obligations might arise from involvement in international organizations," but noting Henkin's increasing discomfort with this position). The issue has arisen with special force in connection with customary international law obligations, see generally Agora: May the President Violate Customary International Law?, 80 Am. J. Int'l L. 913 (1986) (debating power of executive branch to violate or abrogate customary international law), and with decisions by the International Court of Justice relating to nonfederal actors, see generally Agora: Breard, $92 \mathrm{Am}$. J. Int'l L. 666 (1998) (debating state sovereignty issues involved in compelling compliance with International Court of Justice decision).

200. For example, states and localities have resisted federal decrees, see Frank B. Cross \& Blake J. Nelson, Strategic Institutional Effects on Supreme Court Decisionmaking, 95 Nw. U. L. Rev. 1437, 1471 \& n.229 (2001), Congress and federal agencies largely disregarded the Supreme Court's declaration that legislative vetoes were unconstitutional, id. at 1471 n.228, and the executive branch sometimes refuses to enforce statutes that the President deems unconstitutional, see Presidential Authority to Decline to Execute Unconstitutional Statutes, 18 Op. Off. Legal Counsel 199 (1994) (defending nonenforcement).

201. Henkin, Foreign Affairs, supra note 15, at 143-48; Ku, supra note 15, at 98-99; see also infra text accompanying notes 219-227 (discussing United States v. Curtiss-Wright Export Corp., 299 U.S. 304 (1936)).

202. Indeed, the fact that international law had domestic and international significance was of paramount concern to the Framers. See Carlos Vazquez, The Four Doctrines of Self-Executing Treaties, 89 Am. J. Int'l L. 695, 697-700 (1995) (describing how Framers intended Supremacy Clause to guarantee that treaties automatically became law in the states); see, e.g., James Madison, Helvidius, No. I, in answer to Pacificus [Alexander Hamilton], on President Washington's Proclamation of Neutrality (1793), reprinted in 1 Letters and Other Writings of James Madison 611, 614-15 (Philadelphia, J.B. Lippincott \& Co. 1867), microfiched on 19th Century Legal Treatises (Research Publications) (explaining significance of Treaty Clause as partly due to the fact that treaties "have sometimes the effect of changing not only the external laws of the society, but operate also on the internal code").

203. The Paquete Habana, 175 U.S. 677, 700 (1900); see also Hilton v. Guyot, 159 U.S. 113, 163 (1895) ("International law, in its widest and most comprehensive sense . . . is 
tional obligations is enough to frame a constitutional question of nondelegation.

\section{B. Nondelegation as an Underenforced Norm}

By analogy to domestic affairs, then, international delegations raise legitimate constitutional questions. But that is scarcely the end of the matter, even as a question of positive law, given the longstanding reluctance to enforce the nondelegation doctrine.

1. The Practice of Underenforcement. - The Supreme Court has described the nondelegation principle as a first principle of constitutional government, ${ }^{204}$ adverted to the doctrine over a reasonably long tenure, ${ }^{205}$ and never renounced it. ${ }^{206}$ At the same time, the doctrine plainly lacks vitality. As much as it has maintained that all legislative delegations are unconstitutional, the Court has also said that they must, under some circumstances, be permitted. ${ }^{207}$ The bottom line is noteworthy. The

part of our law.”). But cf. Garcia-Mir v. Meese, 788 F.2d 1446, 1454 \& n.9 (11th Cir. 1986) (finding "sufficiently express evidence of congressional intent as to interdict the application of international law" with respect to certain indefinitely detained aliens); id. at 1454-55 (finding that decision by Attorney General constituted a controlling executive act, and a prior circuit court decision constituted a controlling judicial decision, so as also to pretermit international law).

204. J.W. Hampton, Jr., \& Co. v. United States, 276 U.S. 394, 406 (1928) (describing delegations of legislative power to executive branch, inter alia, as "a breach of the National fundamental law"); Field v. Clark, 143 U.S. 649, 692 (1892) ("That Congress cannot delegate legislative power to the President is a principle universally recognized as vital to . . . the system of government ordained by the Constitution.").

205. See, e.g., Whitman v. Am. Trucking Ass'ns, 531 U.S. 457, 472 (2001) ("In a delegation challenge, the constitutional question is whether the statute has delegated legislative power to the agency. Article I, $\S 1$, of the Constitution vests '[a]ll legislative Powers herein granted . . . in a Congress of the United States.' This text permits no delegation of those powers ...." (quoting Loving v. United States, 517 U.S. 748, 771 (1996))); Mistretta v. United States, 488 U.S. 361, 372 (1989) ("Congress generally cannot delegate its legislative power to another Branch.”); United States v. Shreveport Grain \& Elevator Co., 287 U.S. 77, 85 (1932) ("That the legislative power of Congress cannot be delegated is, of course, clear."); Field, 143 U.S. at 692 ("Congress cannot delegate legislative power to the President ....").

206. Indeed, then-Justice Rehnquist would have based at least two decisions on the doctrine. Am. Textile Mfrs. Inst. v. Donovan, 452 U.S. 490, 543-48 (1981) (Rehnquist, J., joined by Burger, C.J., dissenting); Indus. Union Dep't v. Am. Petroleum Inst., 448 U.S. 607, 671-88 (1980) (Rehnquist, J., concurring). Justice Thomas, moreover, would have it broadened. See Whitman, 531 U.S. at 487 (Thomas, J., concurring) (faulting intelligible principle doctrine for failing to "prevent all cessions of legislative power," since "there are cases in which the principle is intelligible and yet the significance of the delegated decision is simply too great for the decision to be called anything other than 'legislative'").

207. See, e.g., Mistretta, 488 U.S. at 372 (“[I]n our increasingly complex society, replete with ever changing and more technical problems, Congress simply cannot do its job absent an ability to delegate power under broad general directives."); Norwegian Nitrogen Prods. v. United States, 288 U.S. 294, 305 (1933) ("What is done by the Tariff Commission and the President in changing the tariff rates to conform to new conditions is in substance a delegation, though a permissible one, of the legislative process."); see also Amalgamated Meat Cutters \& Butcher Workmen of N. Am. v. Connally, 337 F. Supp. 737, 
Court has struck down statutes on nondelegation grounds only twice, ${ }^{208}$ and not since 1935, despite a fair number of opportunities. ${ }^{209}$ Adverting to this history, Cass Sunstein quipped that the doctrine "has had one good year, and 211 bad ones (and counting)."210 Gary Lawson tallied the combined vote by members of the Supreme Court as standing 53-0 against the nondelegation doctrine over a recent twelve-year span. ${ }^{211}$

So far as one can tell, this pathetic history does not signal that the Court has rejected the doctrine's premise-that only Congress may constitutionally exercise legislative authority. The problem, instead, seems to be the lack of any judicially manageable standard. ${ }^{212}$ The recent decision in Whitman v. American Trucking illustrates contemporary attitudes perfectly. A panel of the D.C. Circuit had held that the Clean Air Act, as then construed, unconstitutionally delegated legislative authority to the Environmental Protection Agency, ${ }^{213}$ but suggested that the EPA might cure the difficulty by adopting a narrowing construction of the statute. ${ }^{214}$ In an opinion by Justice Scalia, the Supreme Court rejected that solution,

745 (D.D.C. 1971) (“[T] he Constitution does not forbid every delegation of 'legislative' power.”). The Court emphasized anew in Whitman that legislative delegations were never permissible, but that the delegation in that case was not legislative in character, provoking Justice Stevens to argue (for himself and Justice Souter) that the better course would simply be to admit that some legislative delegations were constitutional. Whitman, 531 U.S. at 487-90 (Stevens, J., concurring).

208. See A.L.A. Schechter Poultry Corp. v. United States, 295 U.S. 495, 539-42 (1935) (striking down delegation of authority to regulate "fair competition" under National Industrial Recovery Act); Pan. Ref. Co. v. Ryan, 293 U.S. 388, 430 (1935) (striking down essentially standardless delegation of authority to promulgate Petroleum Code under National Industrial Recovery Act). As the Court explained in Mistretta, in Schechter and Panama Refining the Court found that Congress not only had utterly failed to cabin the authorities' discretion, but also either had criminalized acts for the first time (Panama Refining, 293 U.S. at 414) or had delegated regulatory power to private parties (Schechter, 295 U.S. at 539-40). 488 U.S. at 373 n.7; see also Clinton v. City of New York, 524 U.S. 417, 486 (1998) (Breyer, J., dissenting) (emphasizing extraordinary character of those circumstances).

209. Mistretta, 488 U.S. at 373-74 (citing examples).

210. Cass R. Sunstein, Nondelegation Canons, 67 U. Chi. L. Rev. 315, 322 (2000) [hereinafter Sunstein, Nondelegation].

211. Lawson, supra note 20, at 330. It seems unfair not to count Justice Thomas's vote in Whitman in nondelegation's win column, since Justice Thomas indicated that he would have voted for a nondelegation challenge had it been properly briefed. Whitman, 531 U.S. at 487 (Thomas, J., concurring).

212. See, e.g., Bradford R. Clark, Separation of Powers as a Safeguard of Federalism, 79 Tex. L. Rev. 1321, 1374 (2001) ("The Court's reluctance to enforce the nondelegation doctrine more vigorously appears to stem from the judiciary's limited institutional competence rather than any fundamental disagreement with the doctrine's goal . . . ."); Manning, Textualism, supra note 149, at 727 (noting that distinguishing between "permissible and impermissible delegations" is "a terrible task" for the judiciary, and that "the Court accordingly has been reluctant to enforce an aggressive interbranch nondelegation doctrine").

213. Am. Trucking Ass'ns., Inc. v. EPA, 175 F.3d 1027, 1034 (D.C. Cir. 1999).

214. Id. at 1038. 
emphasizing that legislative delegations were never permissible ${ }^{215}$ and could not be cured by agency self-restraint. ${ }^{216}$ At the same time, Justice Scalia reiterated his view-originally authored in dissent—-that "we have 'almost never felt qualified to second-guess Congress regarding the permissible degree of policy judgment that can be left to those executing or applying the law." "217 Without necessarily endorsing the Court's commitment to nondelegation in theory, commentators generally side with its decision to steer clear of applying it in practice. ${ }^{218}$

The nondelegation doctrine becomes still feebler, if that is possible, in the realm of foreign affairs. That international delegations deserve different treatment is conventionally traced to United States v. CurtissWright Export Corp., in which the Court opined that "congressional legislation which is to be made effective through negotiation and inquiry within the international field must often accord to the President a degree of discretion and freedom from statutory restriction which would not be admissible were domestic affairs alone involved."219 Curtiss-Wright remains

215. Whitman, 531 U.S. at 472.

216. Id. at 472-73. For the preceding debate concerning whether agencies could be trusted to resolve nondelegation problems, compare, e.g., Lisa Schultz Bressman, Schechter Poultry at the Millennium: A Delegation Doctrine for the Administrative State, 109 Yale L.J. 1399, 1422-31 (2000) (arguing that administrative standards improve accountability and promote other nondelegation virtues), and Cass R. Sunstein, Is the Clean Air Act Unconstitutional?, 98 Mich. L. Rev. 303, 349-61 (1999) (defending use of administrative standards to constrain administrative discretion), with Mark Seidenfeld \& Jim Rossi, The False Promise of the "New" Nondelegation Doctrine, 76 Notre Dame L. Rev. 1, 15-16, 19 (2000) (arguing against administrative nondelegation doctrine).

217. Whitman, 531 U.S. at 474-75 (quoting Mistretta v. United States, 488 U.S. 361, 416 (1989) (Scalia, J., dissenting)). Justice Scalia had earlier added the following:

$[\mathrm{W}]$ hile the doctrine of unconstitutional delegation is unquestionably a fundamental element of our constitutional system, it is not an element readily enforceable by the courts. Once it is conceded, as it must be, that no statute can be entirely precise, and that some judgments, even some judgments involving policy considerations, must be left to the officers executing the law and to the judges applying it, the debate over unconstitutional delegation becomes a debate not over a point of principle but over a question of degree.

Mistretta, 488 U.S. at 415-16 (Scalia, J., dissenting).

218. See, e.g., Richard J. Pierce, Jr., Political Accountability and Delegated Power: A Response to Professor Lowi, 36 Am. U. L. Rev. 391, 393-403 (1987) (arguing that courts are "institutionally incapable of creating and applying a delegation doctrine" that limits legislative grants of discretion); Richard B. Stewart, Beyond Delegation Doctrine, 36 Am. U. L. Rev. 323, 324-28 (1987) (agreeing with Pierce, supra, and concluding that there are no "judicially manageable and defensible criteria to distinguish permissible from impermissible delegations"); Sunstein, Nondelegation, supra note 210, at 327 (speculating that the reason is likelihood that "judicial enforcement of the doctrine would produce ad hoc, highly discretionary rulings" that would "suffer from the appearance, and perhaps the reality, of judicial hostility to the particular program at issue”). See generally id. at 317-28 (summarizing case against judicial enforcement).

219. 299 U.S. 304, 320 (1936). After citing recurring legislative practice that respected the need for executive autonomy, the Court added:

[I] $\mathrm{t}$ is evident that this court should not be in haste to apply a general rule which will have the effect of condemning legislation like that under review as 
controversial,220 and its precise reasoning may have few contemporary adherents, ${ }^{221}$ but subsequent cases have certainly echoed its notion of applying a (still) more deferential approach to delegations in relating to foreign affairs. ${ }^{222}$ Although Chief Justice Rehnquist advocated enforcing the domestic nondelegation doctrine while an Associate Justice, he had in

constituting an unlawful delegation of legislative power. The principles which justify such legislation find overwhelming support in the unbroken legislative practice which has prevailed almost from the inception of the national government to the present day.

Id. at 322 .

220. E.g., Harold Hongju Koh, The National Security Constitution: Sharing Power After the Iran-Contra Affair 94 (1990) [hereinafter Koh, National Security Constitution] (summarizing "withering criticism" of Curtiss-Wright); see Bradley, International Delegations, supra note 3, at 1583 \& n.126 (citing critical authorities). Many are particularly frustrated with the notion that the President can be delegated unlimited discretion in the exercise of the war powers. See, e.g., John Hart Ely, War and Responsibility: Constitutional Lessons of Vietnam and Its Aftermath 24-25 (1993) [hereinafter Ely, War] (arguing, halfheartedly, for application of nondelegation doctrine in connection with war powers); Francis D. Wormuth \& Edwin B. Firmage, To Chain the Dog of War: The War Power of Congress in History and Law 210-19 (2d ed. 1989) (arguing wholeheartedly for such application).

221. See Roy E. Brownell II, The Coexistence of United States v. Curtiss-Wright and Youngstown Sheet $\mathcal{E}$ Tube v. Sawyer in National Security Jurisprudence, 16 J.L. \& Pol. 1, 14-15 (2000) (analyzing compatibility of Curtiss-Wright and the Steel Seizure Case); Edward T. Swaine, Negotiating Federalism: State Bargaining and the Dormant Treaty Power, 49 Duke L.J. 1127, 1142 nn.46-47 (2000) [hereinafter Swaine, Negotiating Federalism] (citing critical authorities, and those questioning continuing influence of underlying constitutional theory).

222. See, e.g., Clinton v. City of New York, 524 U.S. 417, 445-46 (1998) (noting that President is granted greater discretion regarding statutes relating to foreign trade than would be permissible if statutes related to domestic affairs); Field v. Clark, 143 U.S. 649, 691 (1892) (" $[\mathrm{I}] \mathrm{n}$ the judgment of the legislative branch of the government, it is often desirable, if not essential for the protection of the interests of our people . . to invest the President with large discretion in matters arising out of the execution of statutes relating to [foreign] trade and commerce ....."); see also Loving v. United States, 517 U.S. 748, 768 (1996) (acknowledging greater deference to congressional delegations in matters involving military affairs); Mistretta, 488 U.S. at 416 (Scalia, J., dissenting) (explaining holding in Yakus v. United States, 321 U.S. 414 (1944), as rooted in wartime exigencies); United States v. Approximately 633.79 Tons of Yellowfin Tuna, 383 F. Supp. 659, 661-62 (S.D. Cal. 1974) ("[W] hen considering a delegation of authority to engage in international negotiations, only the most clear abuse or true congressional abdication or a violation of individual constitutional rights should lead to the invalidation of the legislation by the courts." (citations omitted)); Amalgamated Meat Cutters \& Butcher Workmen of N. Am. v. Connally, 337 F. Supp. 737, 754 (D.D.C. 1971) ("The consequence for international trade, liquidity and monetary relationships, enhances the range of power Congress may permissibly delegate to the President.”). But see Michael J. Glennon, The NATO Treaty: The Commitment Myth, in First Use of Nuclear Weapons 51, 57 (Peter Raven-Hansen ed., 1987) ("[T]he Court appears in successive stages to have backed steadily away" from "exempting foreign affairs powers from the operation of the [non]delegation doctrine ...."). 
prior government service expressed the view that nondelegation simply "does not apply in the field of external affairs." 223

The Court has never taken such an extreme position, and the import of its case law seems more modest. Given the relative breadth of national authority over foreign affairs, it is probable that limits on congressional power established in the domestic sphere-like nondelegation-do not apply with precisely the same force to treaties and congressional-executive agreements. ${ }^{224}$ On the other hand, there is no precedent legitimating delegations through the President to international institutions, ${ }^{225}$ and some opinions caution that Congress remains subject to constitutional limits. ${ }^{226}$ The absence of any case law more clearly establishing an international nondelegation doctrine may plausibly be attributed to the Senate's (relatively) strict constraints on international delegations. ${ }^{227}$ At present, the only safe conclusion is that, in foreign as in domestic matters, the Court will be disinclined to enforce any limits it may perceive.

223. William H. Rehnquist, The Constitutional Issues-Administration Position, 45 N.Y.U. L. Rev. 628, 637 (1970).

224. See, e.g., Michael B. Rappaport, The Selective Nondelegation Doctrine and the Line Item Veto: A New Approach to the Nondelegation Doctrine and Its Implications for Clinton v. City of New York, 76 Tul. L. Rev. 265, 271 (2001) (“[T] he nondelegation doctrine probably does not apply to various matters, including foreign and military affairs, foreign commerce, rules governing the internal operations of the judiciary and the executive, and the management of governmental real estate."). The persuasiveness of this view depends in part, of course, on whether the federal government's authority over foreign affairs is genuinely plenary. There is case law supporting that conclusion, see, e.g., Missouri v. Holland, 252 U.S. 416, 432-35 (1920) (upholding federal government's power to make and enforce treaties that conflict with powers reserved to states), but it has become newly controversial. See generally Edward T. Swaine, Does Federalism Constrain the Treaty Power?, 103 Colum. L. Rev. 403 (2003) [hereinafter Swaine, Treaty Power] (evaluating federalism constraints on the treaty power in light of "new federalism" displayed in recent Supreme Court decisions).

225. Bradley, International Delegations, supra note 3, at 1584 ("Curtiss-Wright concerned a delegation within the U.S. system, between Congress and the President, not an international delegation."); see Nathaniel L. Nathanson, The Constitution and World Government, 57 Nw. U. L. Rev. 355, 368-69 (1962) (suggesting that Curtiss-Wright may be inapplicable to international delegations).

226. E.g., Perez v. Brownell, 356 U.S. 44, 58 (1958) ("Broad as the [foreign affairs] power ... must necessarily be, it is not without limitation. The restrictions confining Congress in the exercise of any of the powers expressly delegated to it in the Constitution apply with equal vigor when that body seeks to regulate our relations with other nations."); Ex parte Quirin, 317 U.S. 1, 25 (1942) ("Congress and the President, like the courts, possess no power not derived from the Constitution.").

227. See Nathanson, supra note 225, at 367 (claiming, in 1962, that the lack of precedent reflects "the reluctance of the Senate to permit any delegations comparable to those which have become common so far as legislation is concerned," and its insistence instead "upon strictest conformity with principles of non-delegability"). It is worth noting, however, that some of the Court's nondelegation cases were suffused with foreign context. See, e.g., Pan. Ref. Co. v. Ryan, 293 U.S. 388, 421-30 (1935); J.W. Hampton, Jr., \& Co. v. United States, 276 U.S. 394, 407 (1928). 
2. Disinterring the Nondelegation Doctrine. - Few call for reviving a fullbore nondelegation doctrine, ${ }^{228}$ and some who do seem resigned to its failure. ${ }^{229}$ For reasons just mentioned, anyone arguing that courts should strike down international delegations based on a disinterred nondelegation doctrine faces a still tougher slog. In the most systematic and persuasive argument for that result, Julian Ku concentrates on closing the gap between domestic and international matters, concluding that courts should take "an active judicial role in policing international delegations." ${ }^{330}$ What remains elusive, however, is a comprehensive answer to the problems bedeviling the doctrine's domestic application. ${ }^{231}$ Professor $\mathrm{Ku}$ suggests that courts should reject functional analysis in favor of formalism, but that distinction seems of little assistance; assuming one can get past the notion of courts electing a rule-bound approach, ${ }^{232}$ there is no clear text or precedent to inform this formalism, ${ }^{233}$ and its principal characteristic seems to be that it would render international delegations unconstitutional rather than permitting them. ${ }^{234}$ It is unclear, moreover,

228. Among its less conflicted proponents, see Sotirios A. Barber, The Constitution and the Delegation of Congressional Power (1975) (questioning argument that Congress's incapacity to manage increased responsibilities of government justifies delegation); John Hart Ely, Democracy and Distrust 131-34 (1980) (arguing that nonenforcement of the delegation doctrine allows legislators to avoid accountability by delegating important policy choices to administrators); Theodore J. Lowi, The End of Liberalism, reprinted in Peter H. Schuck, Foundations of Administrative Law 163, 166-67 (1994) (lamenting that "delegation has been elevated to the highest of virtues, and standards have been relegated to the wastebasket of history because that is the logic of interest-group liberalism"); Schoenbrod, supra note 9, at 3 ("When the lawmakers we elect have others make the law, the people lose."); Peter H. Aranson et al., A Theory of Legislative Delegation, 68 Cornell L. Rev. 1, 63-67 (1982) ("[A] renewed nondelegation doctrine ... should reduce the use of regulation to produce private benefits and to satisfy high demanders at collective cost ...."); Lawson, supra note 20, at 333-35 (explaining that nondelegation doctrine is within original meaning of the Constitution).

229. See, e.g., Ely, War, supra note 220, at 24-25 (counting himself among the few arguing for reviving the nondelegation doctrine, but acknowledging that such a revival would require "another Vietnam" and even then would likely not last).

230. Ku, supra note 15, at 131; see id. at 131-44 (identifying objections to judicial review of international delegations and offering reasons why such review is "necessary and desirable").

231. See supra note 218 (citing reservations by leading commentators about application of nondelegation doctrine to domestic matters).

232. It is clearly a discretionary, case-by-case matter under his approach, rather than any fundamental jurisprudential commitment. E.g., Ku, supra note 15, at 76-77.

233. The argument, indeed, is that courts have failed the nondelegation doctrine by refusing formalism in the past. Id. at 116-17. Professor Ku alludes to "a few exceptions in the now distant past," but cites to Professor Krent for his conclusion that delegations to third parties could not withstand formalist scrutiny. Id. at 120 (citing Harold J. Krent, Fragmenting the Unitary Executive: Congressional Delegations of Administrative Authority Outside the Federal Government, 85 Nw. U. L. Rev. 62, 68 (1990)).

234. Thus, Professor Ku explains that while "[a]t first glance, international delegations fall neatly into the Court's constitutional system, creating no serious difficulties ... [t] his view depends ... on the adoption of a functionalist approach to constitutional interpretation," whereas formalist analysis shows that they suffer from "two serious 
how one would adapt doctrinal cornerstones-such as the insistence that Congress provide a guiding "intelligible principle" to its agent ${ }^{235}$ — to the international setting, where Congress itself may have little control over the principles ultimately conveyed. ${ }^{236}$

Even assuming a solution to these problems, asking the courts to revert to a more stringent approach-in the international context to boot-is likely to encounter fatal resistance. The backlash that marked the nondelegation doctrine's heyday, ${ }^{237}$ and the belief that national political powers (and the urge to delegate) are at their zenith in foreign affairs, ${ }^{238}$ will tempt courts to invoke nonjusticiability doctrines to betray any nondelegation revival. ${ }^{239}$ The consequences of that betrayal, moreover, may be worse than if matters were left alone. If passing muster under a reinvigorated standard may confer legitimacy upon the organization in

institutional failings"-lack of accountability and lack of legitimacy. Ku, supra note 15, at 130 .

235. See supra notes 172, 206 and accompanying text (discussing intelligible principle requirement).

236. See infra text accompanying notes 286-296 (discussing problem posed by multiple principals).

237. See A. Michael Froomkin, Wrong Turn in Cyberspace: Using ICANN to Route Around the APA and the Constitution, 50 Duke L.J. 17, 143 (2000) (describing nondelegation doctrine as "carry[ing] some heavy baggage").

238. See supra text accompanying notes 219-223. For examples postdating Ku's work, see American Insurance Ass'n v. Garamendi, 539 U.S. 396, 414-15 (2003) (referring to broad congressional authority and extratextual presidential authority in foreign relations (citing United States v. Curtiss-Wright Exp. Corp., 299 U.S. 304 (1936))); id. at 416 ("While a sharp line between public and private acts works for many purposes in the domestic law, insisting on the same line in defining the legitimate scope of the Executive's international negotiations would hamstring the President in settling international controversies."); id. (cautioning against "transplanting 'judicial subtleties' of domestic law into "the solution of analogous problems between friendly nations"” (quoting United States v. Pink, 315 U.S. 203, 234-42 (1942) (Frankfurter, J., concurring))); Crosby v. National Foreign Trade Council, 530 U.S. 363, 380-81 (2000) (explaining that "[a]s with Congress's explicit delegation to the President of power over economic sanctions, Congress's express command to the President to take the initiative for the United States among the international community invested him with the maximum authority of the National Government in harmony with the President's own constitutional powers" (citation omitted)).

239. See, e.g., Goldwater v. Carter, 444 U.S. 996, 997 (1979) (Powell, J., concurring in the judgment) (declining to review presidential authority to terminate treaties on ripeness grounds); id. at 1002, 1003-06 (Rehnquist, J., concurring) (invoking political question grounds). Not all such invocations will be persuasive-for example, the delegations may have domestic consequences, and the political solutions may be less obvious, contrast id. at 1004-05, but alternative bases for abstention are likely to be available, particularly if the President chooses not to object. Cf. Youngstown Sheet \& Tube Co. v. Sawyer, 343 U.S. 579, 635-37 (1952) (Jackson, J., concurring) (contending that presidential authority "is at its maximum" when exercised consistent with congressional authorization, "for it includes all that he possesses in his own right plus all that Congress can delegate . . . If his act is held unconstitutional under these circumstances, it usually means that the Federal Government as an undivided whole lacks power"). 
question, ${ }^{240}$ it raises the specter that international delegations with pernicious effects might be legitimated by a reinvigorated, but porous, judicial review.

The more popular method for resuscitating nondelegation has been to find a more flexible tool. Some appealing possibilities for coping with underenforced norms-self-enforcement, self-help, and third-party intervention-are unlikely to be of assistance in coping with international delegations. $^{241}$ The principal alternative, occasionally employed by the Supreme Court, has been to interpret delegations narrowly. ${ }^{242}$ In Kent $v$. Dulles, for example, the Supreme Court invoked liberty and nondelegation interests in reading narrowly the Secretary of State's discretion to evaluate the passport application of a Communist Party member. ${ }^{243}$

240. Ku, supra note 15 , at 143 ("If a court finds that a challenged international delegation can fit within the Constitution's formal structural requirements, a court (and in the U.S. system perhaps only a court) can confer upon an international organization the independent source of political legitimacy that it currently lacks.”). Professor $\mathrm{Ku}$ elsewhere notes, however, that international organizations may in fact suffer both from illegitimacy, id. at 126-30, as well as a lack of accountability, id. at 121-26, so any whitewashing may be undesirable.

241. See, e.g., Sager, Fair Measure, supra note 17, at 1227 (describing general obligation of officials to avoid unconstitutional conduct); id. at 1239-41 (describing potential for Congress to enforce Section 5 of the Fourteenth Amendment beyond the Supreme Court's construction); id. at 1248-50 (proposing that the Supreme Court should decline to "polic[e] state courts against overly generous interpretations of federal constitutional values"). Both supporters and critics of the nondelegation doctrine suppose that Congress utilizes delegation for its own ends, so it is hard to rely on national political intervention as a complete solution. In the international context, moreover, the judiciary's heightened deference to the political branches is more than matched by Congress's own deference to the executive branch, to which it may effectively delegate any policing of nondelegation as well. State courts play a limited role in matters involving foreign affairs, and the states as a whole appear to have no legally protected role in foreign affairs. As G. Edward White has noted, "the early-twentieth-century transformations of the constitutional jurisprudence of foreign relations had the effect of eliminating state legislatures and state courts as contributors to the jurisprudence." G. Edward White, Observations on the Turning of Foreign Affairs Jurisprudence, 70 U. Colo. L. Rev. 1109, 1118 n.24 (1999). State court interventions were slapped down in Zschernig v. Miller, 389 U.S. 429, 432-35 (1968), which seemingly remains good law. See Garamendi, 539 U.S. at 417-19 (discussing Zschernig).

242. John F. Manning, The Nondelegation Doctrine as a Canon of Avoidance, 2000 Sup. Ct. Rev. 223, 223 [hereinafter Manning, Canon of Avoidance] ("The nondelegation doctrine ... now operates exclusively through the interpretive canon requiring avoidance of serious constitutional questions.”); Sunstein, Nondelegation, supra note 210, at 342 (reviewing various nondelegation canons "show[ing] that the nondelegation doctrine is alive and well. It has merely been relocated and left unnamed."); see, e.g., Mistretta v. United States, 488 U.S. 361, 373 n.7 (1989) ("In recent years, our application of the nondelegation doctrine has been limited . . . to giving narrow constructions to statutory delegations that might otherwise be thought to be unconstitutional.”); Indus. Union Dep't v. Am. Petroleum Inst., 448 U.S. 607, 646 (1980) ("A construction of the statute that avoids this kind of open-ended grant should certainly be favored.”).

243. 357 U.S. 116, 129 (1958) (explaining that implicated liberty interest could only be regulated by Congress, "[a]nd if that power is delegated, the standards must be adequate to pass scrutiny by the accepted tests"; further, "[w] here activities or enjoyment, 
Whatever the general merits of interpretive solutions to underenforcement, ${ }^{244}$ they seem inappropriate to a terminal case like nondelegation-that is, if there is so little to the nondelegation doctrine proper, why pervert statutory interpretation?245 (Conversely, if there is a genuine basis for the nondelegation doctrine, an interpretive canon only goes partway to eliminate the problem, since in the case of clearly written statutes the nondelegation doctrine will continue to be underenforced. ${ }^{246}$ ) Putting this to one side, the interpretive approach seems self-defeating. As John Manning has observed, "If the point of the nondelegation doctrine is to ensure that Congress makes important statutory policy, a strategy that requires the judiciary, in effect, to rewrite the terms of a duly enacted statute cannot be said to serve the interests of that doctrine."247 That conundrum is particularly pronounced in foreign affairs. Because the courts often defer to the President's construction of foreign relations statutes, ${ }^{248}$ or choose on their own to interpret statutes so as to confer substantial powers on him, ${ }^{249}$ the delegated power to interpret runs through the courts to the executive branch—not the same thing as delegating to international institutions, but surely inconsistent with the basic concern.

A different interpretive tack would be to adopt a non-self-execution presumption. ${ }^{250}$ As elaborated by Curtis Bradley, courts could presume

natural and often necessary to the well-being of an American citizen, such as travel, are involved, we will construe narrowly all delegated powers that curtail or dilute them"); see Schoenbrod, supra note 9, at 41-42 (discussing civil liberties reading of Kent v. Dulles, and bemoaning failure to extrapolate it to liberty interests protected by broader nondelegation doctrine).

244. For a sustained defense, see Young, Constitutional Avoidance, supra note 17, passim.

245. Cf. Posner \& Vermeule, Interring, supra note 23, at 1761 ("Statutory interpretation that construes delegations narrowly can be justified, if at all, only on the ground that the underlying interpretive theory lets the judges employ clear statement canons that lack constitutional underpinnings.").

246. Those genuinely concerned about nondelegation, consequently, do not seem to put much stock in the solution. See, e.g., Schoenbrod, supra note 9, at 44-45 (describing the Court's repeated failure to adequately clarify or define its position on nondelegation).

247. Manning, Canon of Avoidance, supra note 242, at 228.

248. See Bradley, International Delegations, supra note 3, at 1586 (citing El Al Israel Airlines, Ltd. v. Tsui Yuan Tseng, 525 U.S. 155, 168 (1999); Sumitomo Shoji Am., Inc. v. Avagliano, 457 U.S. 176, 185 (1982), and Kolovrat v. Oregon, 366 U.S. 187, 194 (1961)). See generally Curtis A. Bradley, Chevron Deference and Foreign Affairs, 86 Va. L. Rev. 649 (2000) (discussing, and defending, deference).

249. See, e.g., Edward T. Swaine, Crosby as Foreign Relations Law, 41 Va. J. Int'l L. 481, 499-501 (2001) (describing Supreme Court's reasoning in attributing broad preemptive scope to federal statute in Crosby).

250. Academics and courts disagree as to whether there already is, or should be, a presumption for or against self-execution. Compare, e.g., United States v. Noriega, 808 F. Supp. 791, 798 (S.D. Fla. 1992) (suggesting that "the courts have generally presumed treaties to be non-self-executing"), and John C. Yoo, Globalism and the Constitution: Treaties, Non-Self-Execution, and the Original Understanding, 99 Colum. L. Rev. 1955, 2092 (1999) [hereinafter Yoo, Globalism and the Constitution] (supporting presumption 
that the outputs of international institutions "do not create enforceable federal law [within the United States] unless and until they are implemented by Congress." ${ }^{251}$ That path may be one that courts and the political branches are intuitively adopting, ${ }^{252}$ but establishing a more systematic principle might lend needed clarity.

That said, the precise warrant for this solution is unclear. Professor Bradley provides an authoritative and illuminating survey of potential delegation objections without stating conclusively which is decisive, and why. ${ }^{253}$ This is consistent with his proposed remedy, which avoids establishing any fixed rules for judicial application, but his analysis also suggests problems with too readily assuming that international delegations are unconstitutional. He brackets the controversy surrounding whether non-self-execution is compatible with the Supremacy Clause by claiming to invoke the doctrine only "by analogy," 254 since U.S. treaty commitments do not "purport to convert the decisions and actions of international institutions into self-executing federal law." ${ }^{255}$ But if the treaties in question do not themselves give domestic legal force to the delegated actions-and a discrepancy between international and domestic law is tolerable-then international delegations are qualitatively different from domestic delegations, since legislative authority exercised by executive agencies typically does have legal force. International delegations are constitutionally troubling, then, only "by analogy," leaving their standing unclear. ${ }^{256}$

Like other interpretive solutions to underenforcement, a presumption of non-self-execution also seems ill tailored. It is unclear whether Professor Bradley's proposal would apply to all emissions from international institutions, solely those violating (or potentially violating) the U.S. Constitution, or perhaps only those exhibiting some aggravating fac-

against self-execution), with Rainbow Navigation, Inc. v. Dep't of the Navy, 686 F. Supp. 354, 357 (D.D.C. 1988) (applying presumption that treaties are self-executing unless contrary intention is expressed), Louis Henkin, U.S. Ratification of Human Rights Treaties: The Ghost of Senator Bricker, 89 Am. J. Int'l L. 341, 346-47 (1995) (arguing for self-execution based, in part, on Supremacy Clause), and Carlos Manuel Vázquez, Laughing at Treaties, 99 Colum. L. Rev. 2154, 2157-58 (1999) (concluding that Supremacy Clause cases adopt presumption favoring self-execution, which may be overcome by clear statement).

251. Bradley, International Delegations, supra note 3, at 1587.

252. Id. at 1591-92 (reviewing decisions); id. at 1592-95 (citing efforts to limit force of U.S. treaties and statutes).

253. He stops short, accordingly, of claiming that the nondelegation doctrine would, even if applied, invalidate international delegations. E.g., id. at 1584 (alluding to "constitutional concerns posed by U.S. involvement with international institutions," including nondelegation doctrine); see id. at 1560-61 (describing nondelegation and other constitutional limits as potentially "relevant to international delegations").

254. Id. at 1588 .

255. Id. at 1589 .

256. If, on the other hand, the analogy is very strong, then a Supremacy Clause objection is not so easily avoided. 
tor. ${ }^{257}$ Given the range of delegations addressed, however, it seems likely to apply quite broadly; if so, it may materially undermine the strength of U.S. international commitments, and diminish the concessions made by other states, without any certain legal warrant.

At the same time, the non-self-execution solution is liable to overlook some of the more pressing problems. Delegated authority would remain entirely enforceable on the international plane; this means that Security Council resolutions, for example, would lack domestic legal effect but retain all their international significance, ${ }^{258}$ and there can be little doubt of the latter's importance. Even in the domestic context, the non-selfexecution proposal underenforces any norm against international delegations. Inadvertent or indifferent delegations, the kind most likely to be checked by Professor Bradley's rule, do not seem as prone to mischief; deliberate and explicit delegations, on the other hand, are least likely to be checked. ${ }^{259}$ If delegations are counterproductive because of what they intend to accomplish, we should be wary of a decision rule that lets pass the most egregious types, unless we are especially confident that clearer statutory language has ensured congressional accountability.

\section{The Continuing Salience of the Nondelegation Doctrine}

While some would reinvigorate the nondelegation doctrine, perhaps the more common reaction to the puzzle of international delegations is to find a way to quit worrying about them. Some do this reluctantlydue, for example, to justiciability concerns-but others, most recently

257. For example, when explaining the gravity of international delegations, Professor Bradley highlights that NAFTA Chapter 19 panels apply U.S. law, see Bradley, International Delegations, supra note 3, at 1576, but also appears to stress the fact that Chapter 11 panels apply international law, id. at 1577 . One could take the view that either is more invasive.

258. As Professor Bradley elaborates, non-self-execution means that such a resolution "would not by itself satisfy the constitutional requirements for the use of force." Id. at 1591. This is, it bears mention, a somewhat unconventional type of non-self-execution. For one, self-execution usually concerns the status of a treaty in courts of law, but Security Council resolutions typically have little pertinence in courts. Foster v. Neilson, 27 U.S. (2 Pet.) 253, 314 (1829) (describing a non-self-executing treaty as one "address[ing] itself to the political, not the judicial department," such that "the legislature must execute [the treaty], before it can become a rule for the Court"); Restatement (Third) of Foreign Relations Law of the United States \$111(3) (1987) (identifying non-self-executing agreements as exceptions to the principle that U.S. courts must give effect to international law and to international agreements of the United States). In any case, many consider this the kind of international commitment that is never directly effective-meaning that an extra presumption of non-self-execution is irrelevant. Id. at $\$ 111 \mathrm{cmt}$. $\mathrm{g}$ ("It has been commonly assumed that an international agreement cannot itself bring the United States into a state of war.").

259. The Pelly and Packwood Amendments, for example, were enacted by Congress specifically in order to make enforceable agreements for which international sanctions were unavailable. Japan Whaling Ass'n v. Am. Cetacean Soc'y, 478 U.S. 221, 224-26 (1986). 
Eric Posner and Adrian Vermeule, mount a frontal attack. ${ }^{260}$ In their view, "there just is no constitutional nondelegation rule, nor has there ever been. The nondelegation position lacks any foundation in constitutional text and structure, in standard originalist sources, or in sound economic and political theory." 261 Instead, what Posner and Vermeule charmingly dub their "naïve view" holds that statutory grants of authority do not transfer legislative authority, but exercise it, making any derivative exercises of authority executive in character. ${ }^{262}$ On this view, legislation should be condemned as delegative only if Congress compromises the legislative authority of its members (for example, by ceding their power to vote); $; 63$ otherwise, nondelegation is simply irrelevant to constitutional analysis. ${ }^{264}$

This argument is appealing, and of evident significance here. If, as Professors Posner and Vermeule say, nondelegation lacks any distinctive legal or normative character, complaints about international delegations should not make it out of the gate. I do not attempt a comprehensive assessment of their argument; ${ }^{265}$ as should be evident from the preceding

260. Cf. Posner \& Vermeule, Interring, supra note 23, at 1721 n.2 (noting relative infrequency of challenges to the merits of nondelegation, and providing an "honor roll of ... serious critiques").

261. Id. at 1722 .

262. Id. at $1723,1725-26$.

263. Id. at 1726 (citing Mistretta v. United States, 488 U.S. 361, 424-25 (1989) (Scalia, J., dissenting)); id. at 1756. Perhaps another example, which they do not cite, is Clinton v. City of New York, in which the Supreme Court held unconstitutional Congress's attempt to delegate to the President (as the Court saw it) a more finely tuned simulation of the legislative power to repeal statutes. 524 U.S. 417, 438-41 (1998). As noted previously, this distinction-between delegations of the power to enact legislation and the power to exercise a member's vote-has been criticized. See supra note 166.

264. Posner \& Vermeule, Interring, supra note 23, at 1724 (“[W]e will deny that the nondelegation idea adds any constitutionally meritorious content to the relevant debates."). They would separately address attempts by Congress to exercise power that it simply does not have-either because the power is enjoyed by the executive branch or by a component of Congress like the Senate. Id. at 1724, 1755, 1758.

265. In order to rehabilitate the doctrine entirely, one would have to evaluate nondelegation's intellectual pedigree, the original understanding, and nineteenth-century case law, since Posner and Vermeule claim not only to have found no support for the nondelegation doctrine in these sources, but also to have found "originalist and Burkean" support for the naive view. Id. at 1736. On its face, at least, Article I's Vesting Clause seems to draw a distinction between legislative and non-legislative powers. If we assume, as Posner and Vermeule concede, that this precludes anyone other than Congress from exercising "legislative Powers," id. at 1729 (quoting U.S. Const. art. I), the Clause naturally poses the further question: Might some transfer of authority by an otherwise proper exercise of Article I be fairly characterized as an unconstitutional divestiture of "legislative Power"? This is not, I think, merely metaphoric, but simply assumes the possibility of inquiring into the equivalence of constitutional functions (as opposed to, say, assuming that only a legislature can ever be said to exercise legislative power). This is, in any event, the assumption of present doctrine. See, e.g., Mistretta v. United States, 488 U.S. 361, 419 (1989) (Scalia, J., dissenting) ("The focus of controversy ... has been whether the degree of generality contained in the authorization for exercise of executive or judicial powers in a particular field is so unacceptably high as to amount to a delegation of legislative powers."). 
discussion, I also do not attempt any dramatic revival of the nondelegation doctrine, which seems plagued by indeterminacy and prone to judicial misapplication. But Posner and Vermeule shrink from focusing on these more mundane complaints, ${ }^{266}$ instead emphasizing that delegations may also be functionally indistinguishable from any other exercise of legislative authority. My limited ambition is to explain why international delegations are distinctive in principle from ordinary legislative acts and deserve evaluation as such.

1. The Welfarist Case for Nondelegation. - Professors Posner and Vermeule address the possibility that delegation harms welfare by "conceal[ing] political transfers from the public, making it more difficult"-as compared to ordinary legislation-"for the public to interfere" with them. ${ }^{267}$ They think it most plausible that Congress does not give away power, but instead retains the ability to discipline its agents-and the public, in turn, retains the ability to discipline Congress, and to promote the public interest to the same degree as without delegation. ${ }^{268}$ Even if the public cannot directly monitor those exercising delegated power, ${ }^{269}$ it may still observe when "Congress has created a mechanism that will make transfers to interest groups," ${ }^{270}$ and prophylactically discipline the kinds of transfers that may be made in the future. ${ }^{271}$ As Posner and Vermeule

For a fuller exchange regarding Posner and Vermeule's historical and textual case against nondelegation, compare Alexander \& Prakash, supra note 166, passim (criticizing Posner and Vermeule's account of the nondelegation doctrine and attempting partial rehabilitation), with Eric A. Posner \& Adrian Vermeule, Nondelegation: A Post-mortem, 70 U. Chi. L. Rev. 1331 (2003) (responding to Alexander and Prakash and extending critique of doctrine).

266. See, e.g., Posner \& Vermeule, Interring, supra note 23, at 1723 ("Our argument is not that the courts lack the competence to enforce a nondelegation doctrine."). But cf. id. at 1731-32 (noting that the naïve view is more readily administrable).

267. Id. at 1746. The relative nature of the problem is central to their argument: Delegation, they suggest, simply is not special, and they query why it should be condemned when, like other legislative mechanisms (e.g., the power to tax), it can be used for good or ill. Id. at 1753. The point is not without force. But it is not unusual for policymakers to attack problems on an incremental basis, without any perceived need to extrapolate the reasoning. The central question is not whether delegation is especially bad, but whether the benefits (in welfarist or democratic terms) of limiting that form of action exceed the costs, including the costs of having recourse to alternative mechanisms.

268. Id. at 1746 .

269. Their account posits a hypothetical in which the media encounter capacity constraints when they try to cover the agencies, id., but it also works if we imagine that the public's ability to process information is constrained, perhaps resulting in less demand and less provision of information on agencies in the first place.

270. Id. Interest groups will, however, keep pace, employing "fire alarm" oversight of the agency decisions affecting their interests to supplement the "police patrol" approach by which Congress itself gathers information-and signaling Congress when their interests are being slighted. Mathew D. McCubbins \& Thomas Schwartz, Congressional Oversight Overlooked: Police Patrols Versus Fire Alarms, 28 Am. J. Pol. Sci. 165, 166, 171-74 (1984).

271. Posner \& Vermeule, Interring, supra note 23, at 1746. Interest groups, again, will anticipate and check their losses from any congressional attempt to defer difficult choices, yielding the same result as with ordinary legislation. Congress may, for example, 
emphasize, Congress also possesses the ability to override agency decisions if it errs in its ex ante calculus. ${ }^{272}$ Given how matters play out, Congress is presumably without any incentive to use delegation instrumentally in the first place.

This account relies heavily on a contested position concerning the interests of Congress (and its delegates), the incentives to delegate (and to accept delegations), the scope of agency losses, and the agency costs of controlling them. If proponents of the nondelegation doctrine typically fall into the "runaway bureaucracy" camp on these issues, Posner and Vermeule surely exemplify its "congressional dominance" rival, and that tilt obscures vulnerabilities in their argument. ${ }^{273}$ The grounds for concern about legislative delegation might increase, for example, if we thought that Congress needed to insulate its agents from intervention in order to increase the credibility of its regulation, ${ }^{274}$ if monitoring and disciplining agents were costly, ${ }^{275}$ or if there were systemic difficulties with ex post ${ }^{276}$ or ex ante ${ }^{277}$ controls. Unfortunately, the theory on these questions far outweighs the data. ${ }^{278}$

wish to divest itself of authority_creating a "regulatory lottery" at the agencies-in order to avoid difficult choices among potential beneficiaries and to save its efforts for more rewarding efforts. Id. at 1746-47 (quoting Aranson et al., supra note 228, at 61). The end result, in their view, is much the same. Disappointed would-be beneficiaries will nevertheless petition Congress to “reverse the agency's decisions, and indeed even to retract the delegation." Id. at 1747 . Interest groups will realize in advance of the lottery that they might benefit or lose from the delegation, "and so they will lobby ex ante about the delegation as vigorously as they would about any other kind of legislation," id., assuming, of course, that they can effectively estimate their prospects in advance and harbor no hopes that their prospects are better under the delegation.

272. E.g., id. at 1748, 1752.

273. For an excellent summary of the literature, including these rival views, see Mark A. Pollack, The Engines of European Integration: Delegation, Agency, and Agenda Setting in the EU ch. 1 (2003).

274. E.g., id. at 23-24, 29-31.

275. E.g., D. Roderick Kiewiet \& Mathew D. McCubbins, The Logic of Delegation: Congressional Parties and the Appropriations Process 27 (1991) ("Agency losses can be contained, but only by undertaking measures that are themselves costly.”).

276. For example, if we assume that the House, Senate, and President have different preferences but achieve a compromise within the Pareto set defined by those preferences, an agency with different preferences can move the policy-perhaps just to the margins of the Pareto set-without enabling a coalition that could agree to overturn the new policy. See Matthew D. McCubbins et al., Structure and Process, Politics and Policy: Administrative Arrangements and the Political Control of Agencies, 75 Va. L. Rev. 431, 435-40 (1989).

277. Congress may, for example, adopt controls in the form of agency design or limits to the agency's discretion on the particular policy question, or rely on ongoing controls, but few believe these are perfect. For a good summary, see David Epstein \& Sharyn O'Halloran, Delegating Powers: A Transaction Cost Politics Approach to Policy Making Under Separate Powers 25-29 (1999).

278. See Pollack, supra note 273, at 33 ("[S]ystematic analyses of institutional choices for delegation are still relatively rare.”). Even hard evidence about congressional authority might matter little if perceptions were sticky: For example, Congress's potential authority over delegated powers, on which Posner and Vermeule heavily rely, would mean little if 
It is reasonable to suppose, in any event, that the welfare consequences of delegation depend on the regulatory environment, ${ }^{279}$ and Posner and Vermeule err in too readily extending their analysis to international delegations. ${ }^{280}$ Even on the domestic front, the relationship be-

voters and interest groups believed in runaway bureaucrats and thereby facilitated congressional evasion. Conversely, if voters perceived the scope of congressional powers to be greater, and its ability to control agency drift more comprehensive, than is actually the case, they would presumably discourage Congress from delegating.

279. Contrast Posner \& Vermeule, Interring, supra note 23, at 1745 (querying why Congress might be different from corporations, for which delegation is presumptively welfare-enhancing); id. at 1749 (describing Congress as accounting for behavior of its agents as would a corporation).

280. Id. at 1757 (denying that "there is [any]thing special about such cases"); id. at 1757-59 (arguing that relevant inquiry is not into nature of entity receiving powers but rather into nature of powers being delegated). Their argument depends in part on supposing that the identity of the delegate is irrelevant for delegations of legislative power, since "the delegation inquiry focuses on the abdication of Congress, the delegator, rather than on the nature of the delegate." Id. at 1757; accord Krent, supra note 233, at 71 ("The nondelegation doctrine is indifferent to the identity of Congress's delegate.”). Article I's Vesting Clause, indeed, suggests a focus on whether "legislative Power[ ]" is at issue, U.S. Const. art. I, $\S 1$, but there is some ambiguity in the Supreme Court's case law. See Whitman v. Am. Trucking Ass'ns, 531 U.S. 457, 488 (2001) (Stevens, J., concurring) ("The proper characterization of governmental power should generally depend on the nature of the power, not on the identity of the person exercising it." (emphasis added)); Youngstown Sheet \& Tube Co. v. Sawyer, 343 U.S. 579, 587 (1957) (asserting that "[t] he President's power to see that the laws are faithfully executed refutes the idea that he is to be a lawmaker"); Clark, supra note 212, at 1382 ("Classification of policymaking discretion as either legislative or executive power may often depend on the identity of the actor in question."); id. at 1385-86 ("Although it is sometimes difficult to characterize broad policymaking discretion as either executive or legislative power in the abstract, the identity of the actor exercising such power largely determines its constitutionality.”); Peter Strauss, Was There a Baby in the Bathwater? A Comment on the Supreme Court's Legislative Veto Decision, 1983 Duke L.J. 789, 797 (noting, but criticizing, reasoning in the Steel Seizure Case).

Posner and Vermeule also suggest that "the delegation inquiry . . . asks what Congress has given away, not who has received the gift," Posner \& Vermeule, Interring, supra note 23, at 1757, but this rephrasing is telling: "[W] hat Congress has given away" plausibly depends upon the effect given the recipient, and the Supreme Court's inquiry has indeed emphasized effects. Clinton v. City of New York, 524 U.S. 417, 489 (1998) (Breyer, J., dissenting) (acknowledging that "there are important differences between the delegation before us and other broad, constitutionally acceptable delegations to Executive Branch agencies," in that agency discretion-as opposed to presidential discretion-is typically more constrained); David J. Barron \& Elena Kagan, Chevron's Nondelegation Doctrine, 2001 Sup. Ct. Rev. 201, 241 (claiming support from "the established, congressional nondelegation doctrine . . . in that it responds to concerns about the accountability and discipline of administrative action by focusing on the identity of the decision maker"). In addition, the Court has sometimes expressed interest in whether the recipient has independent constitutional authority. See, e.g., Clinton, 524 U.S. at 445-46 (noting additional discretion permissibly afforded to President in matters of foreign affairs); Loving v. United States, 517 U.S. 748, 768 (1996) (citing the President's Commander-inChief authority as additional basis for permitting Congress to delegate "wide discretion and authority"). By either measure, international delegations - to institutions entirely absent from the face of the Constitution-might merit distinct treatment. 
tween Congress and the President is meaningfully different in foreign affairs. Posner and Vermeule's discussion of congressional accountability assumes that Congress possesses plenary authority over the issue area, and may retain or retract any welfare-reducing transfers. But Congress is generally considered less influential in foreign affairs, where the President's constitutional authority, administrative capacity, expertise, and access to information offer distinct advantages. ${ }^{281}$ The President may also gain leverage, and reduce public accountability, by virtue of his ability to choose among several distinct routes for international lawmaking. ${ }^{282}$

To the extent that international delegations run through the President, then, their hazards may be distinct. When the President's view diverges from that held by Congress, he may more effectively thwart attempts to hold the international institution, and Congress, accountable. ${ }^{283}$ When the President sides with Congress, the problem may be still more serious. As Robert Cooter has noted, interbranch dele-

281. See generally, e.g., Cecil V. Crabb, Jr., et al., Congress and the Foreign Policy Process (2000) (discussing factors limiting congressional assertiveness in foreign policy); Barbara Hinckley, Less Than Meets the Eye: Foreign Policy Making and the Myth of the Assertive Congress (1994) (arguing that congressional struggle for increased power in foreign affairs is largely illusory and that congressional assertiveness in this area may have decreased in recent years); Koh, National Security Constitution, supra note 220, at 123-33 (discussing congressional acquiescence); Stephen R. Weissman, A Culture of Deference: Congress's Failure of Leadership in Foreign Policy 12-16 (1995) (describing congressional efforts at foreign policy as "reactive" and "well below even its general norm," due largely to lack of constituent interest). Lisa Martin has suggested that these views may be ill informed, since legislative influence may be subtle, and even nonexistent when anticipated in equilibrium. Lisa L. Martin, Democratic Commitments: Legislatures and International Cooperation 7-8 (2000) [hereinafter Martin, Democratic Commitments]. She would not deny, however, that legislatures tend to be more dependent on executive agents in international matters. Id. at 24.

282. Cf. Laurence H. Tribe, Taking Text and Structure Seriously: Reflections on Free-Form Method in Constitutional Interpretation, 108 Harv. L. Rev. 1223, 1267 (1994) (arguing that impact of international agreement on U.S. sovereignty determines its status as a treaty).

283. Thomas Franck elaborated:

It is true that this transfer [from Congress to the President to an international regime] is contingent. Congress, by subsequent legislation, can block domestic implementation of treaty norms or of treaty implementing decisions made by an instrumentality established by a treaty. Realistically, however, it can do so only if it musters a two-thirds majority whenever the President chooses to act on the authority of the international regime, in which the U.S. Executive is usually wellrepresented. The effect of such a treaty regime, then, may be seen as potentially creating a new, less accountable, locus of foreign relations power consisting of the presidency and the transnational regime acting in concert. Some Americans have problems with both the wisdom and the constitutionality of such transfers of authority.

Thomas M. Franck, Can the United States Delegate Aspects of Sovereignty to International Regimes?, in Delegating State Powers: The Effect of Treaty Regimes on Democracy and Sovereignty 1, 4-5 (Thomas M. Franck ed., 2000). It seems doubtful, however, that the President will often take the side of an international institution in concerted opposition to Congress. 
gations from a powerful branch to a weak branch presumptively disperse power, but interbranch delegation from a weaker to a stronger branch may "concentrate state powers" and so "remove[ ] obstacles to a political cartel."284

On the international plane, furthermore, the distinctive character of international institutions has significant consequences for delegations. ${ }^{285}$ One pervasive difference has to do with the number and nature of the principals involved. ${ }^{286}$ To be sure, multiple principals with varying objectives (for starters, the President, House of Representatives, and the Senate) may also be involved in domestic matters, ${ }^{287}$ but the assumption of an imperial Congress, with plenary authority, is relatively plausible. In contrast, a central premise of international delegations is that national governments lack plenary authority—and are willing to surrender some of the authority they do possess for the sake of securing cooperation from other nations, achieving productive centralization, and taking advantage of agency competences. ${ }^{288}$

284. Robert D. Cooter, The Strategic Constitution $89 \&$ n.20 (2000). These are not the only possibilities, and the President may actually serve to limit any welfare losses due to delegation. For example, by serving as a more genuine representative of the national weal than Congress, the President may facilitate the organization of otherwise diffuse interests (for example, pro-trade exporters) on the international plane. See Lisa L. Martin \& Beth A. Simmons, Theories and Empirical Studies of International Institutions, in International Institutions 437, 456 (Lisa L. Martin \& Beth A. Simmons eds., 2001) (noting that "actors who have the most to gain from pursuit of general welfare-such as executives elected by a national constituency-will show the most interest in turning to international institutions under such circumstances"); Judith Goldstein, International Law and Domestic Institutions: Reconciling North American "Unfair" Trade Laws, 50 Int'l Org. 541, 556-57, 559-60 (1996) [hereinafter Goldstein, International Law]; see also John O. McGinnis \& Mark L. Movsesian, Against Global Governance in the WTO, 45 Harv. Int'l L.J. (forthcoming 2004) (on file with the Columbia Law Review) (discussing WTO); John O. McGinnis \& Mark L. Movsesian, The World Trade Constitution, 114 Harv. L. Rev. 511 (2000) [hereinafter McGinnis \& Movsesian, World Trade Constitution] (same). As a general matter, though, the President's authority over foreign affairs seems to diminish the opportunity to discipline delegations.

285. I rely here solely on differences perceivable within a rationalist framework, but other accounts of international relations would accentuate the differences between international and domestic delegations. Constructivism, in particular, might put far greater stress on the "pathologies" of international organizations, including undesirable behavior that would reduce the authority of principals. See generally Michael N. Barnett \& Martha Finnemore, The Politics, Power, and Pathologies of International Organizations, 53 Int'l Org. 699, 699 (1999) (discussing "power of [international organizations] and their propensity for dysfunctional, even pathological, behavior").

286. The analytic premise, again, is that Congress (or the national government) is the relevant principal. Considering interest groups as the true principals would have a leveling function, though there would continue to be divergences among each nation's domestic interests.

287. Pollack, supra note 273 , at $43-44$.

288. See generally, e.g., Kenneth W. Abbott \& Duncan Snidal, Why States Act Through Formal International Organizations, in The Politics of Global Governance: International Organizations in an Interdependent World 9 (Paul F. Diehl ed., 2d ed. 
The multiplicity of principals has implications both for initial delegations and for their policing. Because an international institution's rules are the result of bargaining, Congress's ideal may require modification in light of other nations' preferences. ${ }^{289}$ (The United States may even have to modify how its preferences are manifested, so as to show internal consensus that enhances credibility, ${ }^{290}$ or alternatively to show discord that restricts the range of bargains to which the United States could agree. ${ }^{291}$ ) Once an international institution has been brokered, moreover, the U.S. government remains one among multiple principals, or becomes part of a collective principal, making it more difficult to correct any drift from its preferences. ${ }^{292}$ Absent the ability to coordinate with the other principals, or to directly influence the institution, the alternatives may be stark. As Paul Stephan summarized:

[L] egislators may have less freedom to alter or repudiate [an international] proposal than they do with respect to domestic measures. As a practical matter, most national legislatures have only two means of disciplining international lawmakers, because substituting a different rule is not an option. They can reject the rule generated through the international process, or they can withhold funds from the lawmaking body. With respect to

2001); Bruno S. Frey, The Public Choice View of International Political Economy, 38 Int'l Org. 199 (1984).

289. Cf. Martin, Democratic Commitments, supra note 281, at 23-24 (describing need to find means of influencing foreign nations to be "one of the fundamental differences-perhaps the fundamental difference-between domestic and foreign policy").

290. One example is what used to be called "fast track" negotiating authority, in which Congress agreed to limit itself to a simplified approval mechanism in order to enhance the President's authority in trade negotiations. See Hal Shapiro \& Lael Brainard, Trade Promotion Authority Formerly Known As Fast Track: Building Common Ground on Trade Demands More Than a Name Change, 35 Geo. Wash. Int'l L. Rev. 1, 1 (2003). For more general discussions of the importance of credible commitments in international relations, and how to achieve them, see, e.g., Jon Hovi, Games, Threats and Treaties: Understanding Commitments in International Relations (1998); Charles Lipson, Why Are Some International Agreements Informal?, 45 Int'l Org. 495, 508-11 (1991); John K. Setear, An Iterative Perspective on Treaties: A Synthesis of International Relations Theory and International Law, 37 Harv. Int'l L.J. 139, 139-42 (1996).

291. Robert D. Putnam, Diplomacy and Domestic Politics: The Logic of Two-Level Games, 42 Int'l Org. 427, 456-58 (1988); see Lisa L. Martin, The Contributions of Rational Choice: A Defense of Pluralism, 24 Int'l Security 74, 79-80 (1999) (noting how these credibility hypotheses may both be maintained, depending upon the context).

292. Daniel L. Nielson \& Michael J. Tierney, Delegation to International Organizations: Agency Theory and World Bank Environmental Reform, 57 Int'l Org. 241, 248-49 (2003). Delegations with a collective principal are said to take place when the agent has a single contract with a principal composed of more than one actor, whereas multiple principals are organizationally distinct entities that have different contracts with the agent. Id. at 247. Nielson and Tierney generally treat international organizations as collective principals, id. at $247-48$, but it is not clear how organizations with tiered memberships-like the UN Security Council—should be categorized. Cf. id. at 254-56 (hedging as to depiction of World Bank). 
multilateral bodies, each of these variants is problematic. Rejection or a dues default may entail exit from the organization generating the rule, not simply negation of a particular proposal. But these organizations offer significant benefits to their members, and few international rules impose costs on a particular country so great as to justify resigning from a desirable club. ${ }^{293}$

To be sure, these phenomena are not unique to the international setting. Congress may also face significant externalities from disciplining domestic agents, and it may in both contexts rationally limit its disciplinary powers in order to buttress a delegation's credibility. But credibility is a more pervasive issue in negotiating the terms of international institutions, where nations have a plainer interest in inhibiting defection in order to promote stable, collaborative investment in the regime. ${ }^{294}$ In the international setting, moreover, one nation's repudiation of an agent does not necessarily kill it or eliminate its impact, as the United States has discovered, ${ }^{295}$ and nations may rationally decide to stick with institutions that nominally harm their interests. ${ }^{296}$

The welfare implications of these differences in any particular case are unclear, and they certainly do not suggest that international delegations invariably detract from national welfare. On the one hand, the abil-

293. Stephan, supra note 12 , at $682-83$.

294. See Raustiala, Rethinking, supra note 12, at 849 (acknowledging possibility that "exit from international economic institutions, though legally permissible-as it expressly is in NAFTA, the IMF, the World Bank, and the WTO, among other economic institutions-can be prohibitively costly for a state," in part because states often join such institutions to "lock-in desired policy outcomes"); Swaine, Unsigning, supra note 119, at 2074-76 (discussing underinvestment in reliance and possible remedies where parties are free to exit a treaty); see also supra text accompanying notes 184-185 (addressing exit as a distinguishing feature of international delegations).

295. See, e.g., Bob Reinalda, Organization Theory and the Autonomy of the International Labour Organization, in Autonomous Policy Making by International Organizations 42, 59 (Bob Reinalda \& Bertjan Verbeek eds., 1998) (describing U.S. withdrawal from, and return to, the ILO); cf. William P. Alford, The Prospective Withdrawal of the United States from the International Labor Organization: Rationales and Implications, 17 Harv. Int'l L.J. 623, 637-38 (1976) (describing how U.S. letter of intent to withdraw from ILO was intended to induce changes in the organization's policies); Robert S. Jordan, Boycott Diplomacy: The U.S., the U.N., and UNESCO, 44 Pub. Admin. Rev. 283 (1984) (observing that effectiveness of multilateral organizations depends on member states' commitment but noting power of strong member states to shape policy through boycott, and discussing alternatives to withdrawal from international organizations).

296. See Bob Reinalda \& Bertjan Verbeek, Autonomous Policy Making by International Organizations: Purpose, Outline and Results, in Autonomous Policy Making by International Organizations, supra note 295, at 1, 3. Refusing to cooperate, for example, may sacrifice a nation's entitlement to continue benefiting from the institution's previous good works, or result in an international standard that is worse than the (admittedly imperfect) standard likely if some influence is maintained. 
ity of interest groups and other constituencies to police Congress, and to advance the public interest, may not be so easily preserved when it comes to international delegations. On the other hand, condemning such delegations risks overlooking why they are made in the first place: They may be the only vehicle for engaging in welfare-enhancing international coordination, and perhaps the circumvention of interest groups itself enhances welfare. ${ }^{297}$ The only safe conclusion, in my view, is to avoid assuming that international delegations resemble ordinary legislation, so as to render the category normatively irrelevant.

2. The Democratic Case for Nondelegation. - Democratic values, including accountability, are frequently invoked as a basis for resisting delegations, ${ }^{298}$ and international delegations again warrant distinctive treatment. Addressing and rejecting the democratic warrant, Professors Posner and Vermeule depend upon many of the same suppositions-that the public will hold Congress accountable, and that Congress can enact ex ante controls and intervene-already discussed in connection with welfarist concerns. ${ }^{299}$ It remains to be demonstrated, they suggest, that

297. See, e.g., McGinnis \& Movsesian, World Trade Constitution, supra note 284, passim. For a more pessimistic view, see Benvenisti, Exit and Voice, supra note 12, passim (arguing that smaller domestic groups take advantage of international processes to advance their interests).

298. See, e.g., James O. Freedman, Review-Delegation of Power and Institutional Competence, 43 U. Chi. L. Rev. 307, 308 (1976) ("The question of whether and upon what conditions Congress should be permitted to delegate legislative power to other institutions is central to the theory of democratic government as well as to the effective performance of administrative agencies."); Louis L. Jaffe, An Essay on the Delegations of Legislative Power: I, 47 Colum. L. Rev. 359, 360 (1947) (noting that "the objection to indiscriminate and illdefined delegation .... expresses a fundamental democratic concern"); cf. Robert A. Dahl, Can International Organizations Be Democratic? A Skeptic's View, in Democracy's Edges 19, 21 (Ian Shapiro \& Casiano Hacker-Cordón eds., 1999) [hereinafter Dahl, International Organizations] (stressing that "in practice, delegation might be so extensive as to move a political system beyond the democratic threshold"). But see Barber, supra note 228, at 34-36 (denying that representation constitutes a warrant for nondelegation independent of constitutional restraints).

299. Posner \& Vermeule, Interring, supra note 23, at 1748. Posner and Vermeule also address the possibility of congressional dissembling, as when Congress "claim[s] victory over some tough problem (for example, pollution), . . but in fact delegates authority to an agency that will have to make the difficult compromises (between clean air and economic growth)"; they respond that Congress can equally engage in "happy talk about nondelegating statutes," and can be held accountable whether or not a delegation is at issue. Id. at 1748-49. That answer is largely convincing, save that a delegating Congress may also trumpet its own intervention against the agency, so as to "take credit coming and going." Morris P. Fiorina, Congress: Keystone of the Washington Establishment 48 (1977); see Epstein \& O'Halloran, supra note 277, at 22-23 (describing Fiorina's theory as "exceptionally cynical"). This is a plausible description of how the United States actually treats the UN. See, e.g., Paul Kennedy \& Bruce Russett, Reforming the United Nations, Foreign Aff., Sept./Oct. 1995, at 56, 70 (acknowledging possibility that "the world community needs a scapegoat for its setbacks and embarrassments, and since democratic governments have to deflect criticism from themselves, one of the United Nations' functions is to take the heat"). 
delegation is any less effective than ordinary legislation at producing policies matching public and interest group preferences. ${ }^{300}$

Particularly given that congressional management of international delegations is imperfect, ${ }^{301}$ it may not be so hard to satisfy this test. Although it is always hazardous to generalize, ${ }^{302}$ there are several reasons to be skeptical about the democratic capacity of international institutions. First, there is as yet no well-defined international community-with informed, engaged, and unified citizens, political parties, and crossnational dialogue-in which a democratic institution might function, ${ }^{303}$ and none

300. Posner \& Vermeule, Interring, supra note 23, at 1753. Their comparison assumes that delegation and nondelegation take place under comparable circumstances, when the choice of method instead depends on Congress's perception of the tradeoffs involved. See Epstein \& O'Halloran, supra note 277, at 10 ("Congress delegates those areas in which the legislative process is least efficient, and, accordingly, we should not expect oversight to be either perfect or desirable.”); id. (“[A] selection bias is at work here: A theory of oversight divorced from a theory of delegation will overlook the fact that those issue areas in which the executive makes policy differ fundamentally from those in which Congress makes policy itself.”).

301. See supra text accompanying notes 273-297.

302. Cf. Philip M. Nichols, Realism, Liberalism, Values, and the World Trade Organization, 17 U. Pa. J. Int'l Econ. L. 851, 856-58 (1996) (cautioning against "[u]ndisciplined comparison of international organizations" in context of discussing participation by nongovernmental organizations).

303. Robert O. Keohane \& Joseph S. Nye, Jr., The Club Model of Multilateral Cooperation and Problems of Democratic Legitimacy 13 (Aug. 31, 2000), at http:// www.ksg.harvard.edu/prg/nye/clubmodel.pdf (on file with the Columbia Law Review) ("International institutions lack the key feature that makes representative democracy possible and that, in democracies, facilitates accountability: an acknowledged public, operating within a political community in which there is a general consensus on what makes public decisions legitimate."); id. ("Minorities are willing to acquiesce to a majority in which they may not participate directly because they feel they participate in some larger community. Such a sense of community is clearly absent at the global level, and creates severe normative as well as practical problems for . . global democracy."); accord Dahl, International Organizations, supra note 298, at 30-31 (arguing that to establish some semblance of international democracy, "[p]olitical leaders would have to create . . . institutions that would provide citizens with opportunities for political participation, influence, and control," "citizens would need to be . . concerned and informed about the policy decisions of international organizations," and "it would be necessary to create an international equivalent to national political competition by parties and individuals seeking office”); see also McGinnis \& Movsesian, World Trade Constitution, supra note 284, at 564 ("Quite simply, there is no global demos."); Robert Post, The Challenge of Globalization to American Public Law Scholarship, 2 Theoretical Inquiries L. 323, 323-33 (2001) (explaining how international legal institutions appear "anomalous and opaque" to constitutional theorists preoccupied with legitimation through "the specific will of an articulate demos" or its judicial proxy). This problem is considered acute even within the European Union, which has much greater transnational identification, and better political mechanisms, than the average international institution. See, e.g., J.H.H. Weiler \& Joel P. Trachtman, European Constitutionalism and Its Discontents, 17 Nw. J. Int'l L. \& Bus. 354, 377-84 (1996-1997) (describing "articulate and powerful No Demos Thesis" commonly voiced concerning European Community, and proposing alternative vision of European demos). 
of the political rights that one might require as preconditions. ${ }^{304}$ Second, since decisionmaking within international institutions results from an admixture of national political authority, ${ }^{305}$ civil society, ${ }^{306}$ and bureaucracy, ${ }^{307}$ international institutions are typically another step removed from national voters. ${ }^{308}$ Third, judicial and other accountability checks on that decisionmaking-which at least arguably reinforce representation in the domestic sphere-are relatively absent in the international sphere. ${ }^{309}$

304. See, e.g., Stein, supra note 12 , at 491-94.

305. This means that voting is done by institutions, not by people. Martin Wolf, Of Tuna, Turtles and Red Herrings, Fin. Times, Nov. 17, 1999, at 27 ("As an agreement among states, the WTO cannot itself be democratic."). Voting by governments, moreover, systematically distorts even indirect political representation, since votes are allocated per state rather than per capita. See Keohane \& Nye, supra note 303, at 13 ("One state:one vote is not democratic because a Maldive Islander would have 1000 times the voting power of a citizen of China.”). This was a divisive issue in the original discussions of the UN, and weighed heavily even upon supporters like Winston Churchill and Henry Cabot Lodge. See Luck, supra note 4, at 29-34. For a sustained critical analysis, see Athena Debbie Efraim, Sovereign (In) equality in International Organizations (2000).

306. A number of commentators have criticized the accountability of NGOs. See, e.g., Claude E. Barfield, Free Trade, Sovereignty, Democracy: The Future of the World Trade Organization 107-08 (2001); McGinnis \& Movsesian, World Trade Constitution, supra note 284, at 571 (characterizing NGOs as "sometimes unaccountable even to their own memberships"); see also Luck, supra note 4, at 303-06 (discussing concerns among Americans that NGOs are unaccountable). Others suggest a more nuanced view, in which NGOs are accountable in different ways-and comparable accountability deficiencies in national governments are also stressed. See generally, e.g., Peter J. Spiro, Accounting for NGOs, 3 Chi. J. Int'l L. 161 (2002); Paul Wapner, Defending Accountability in NGOs, 3 Chi. J. Int'l L. 197 (2002). But see Peter J. Spiro, New Global Potentates: Nongovernmental Organizations and the "Unregulated" Marketplace, 18 Cardozo L. Rev. 957, 963 (1996) (noting concerns regarding lack of accountability of NGOs to their memberships).

307. See, e.g., Stein, supra note 12, at 491 (describing perception that intergovernmental organizations are "governed by an elite group of national officials who are instructed by their respective executives, and by international secretariats whose staffs at times act independently of the top IGO management”). See generally Barnett \& Finnemore, supra note 285, passim (describing tendency of international organizations to succumb to pathologies of all institutions, notwithstanding supervision by member states).

308. See, e.g, Eyal Benvenisti, Welfare and Democracy on a Global Level: The WTO as a Case Study, in The Welfare State, Globalization, and International Law 343, 347 (Eyal Benvenisti \& Georg Nolte eds., 2004) (noting “doubly-indirect democracy" governing global institutions). For a forceful example of this criticism, see Thiessen, supra note 10, at 66 ("[T] he new global order is fundamentally undemocratic. It represents a massive concentration of power in the hands of unelected bureaucrats who preside over unaccountable institutions that are further and further removed from the people affected by their decisions.”); see also supra text accompanying notes 12, 14 (citing criticisms of international delegation).

309. See, e.g., Kal Raustiala, Sovereignty and Multilateralism, 1 Chi. J. Int'l L. 401, 412-13 (2000) (contrasting prevalence of accountability mechanisms in democraciessuch as judicial review of agency decisions, "intelligible principle" standard, and congressional and budgetary oversight-with relative absence of such mechanisms in international institutions). 
The relevant comparison, indeed, may be even more parochial and stark. One may fairly assume that democratic accountability is at its nadir on matters involving foreign affairs-so that the relative cost of surrendering control to international institutions is lower than normal ${ }^{310}$ - and further assume that the competence of national democratic decisionmaking is most compromised in those matters finding their way to the international plane. ${ }^{311}$ Nonetheless, international institutions are at least less democratically accountable than are U.S. political institutions to U.S. citizens. ${ }^{312}$ Consequently, if U.S. citizens wanted to maximize their political control over the resolution of a given issue, they would choose-were it practicable-any number of domestic institutions over their international alternatives. Robert Dahl's perspective is instructive: While an incisive critic of constitutional democracy in the United States, ${ }^{313}$ he is still more adamant in his judgment that "democracy is unattainable in international organizations." ${ }^{14}$ If international delegations unnecessarily shift decisionmaking to such institutions, and away from Congress, it is at least plausible that they impair democratic values.

\section{Balancing Nondelegation}

It is a small step from considering the normative bases for the nondelegation doctrine to assessing the impact of international delegations on other constitutional values. Some of these values-for example,

310. See, e.g., Stein, supra note 12, at 490 (claiming that the new character of foreign affairs in democratic systems "makes citizen participation more remote, and parliamentary control over the executive, notoriously loose in foreign affairs matters, becomes even less effective"). Robert Dahl makes this point at length, including by citing the American public's lack of engagement with the U.S. decision to enter NAFTA. Dahl, International Organizations, supra note 298, at 23-30; see also Goldstein, International Law, supra note 284, at 541, 557-62 (discussing presidential autonomy in U.S. trade policy). Nevertheless, he does not seem to regard it as closing the gap between national and international democratic processes. Dahl, International Organizations, supra note 298, at 23-30.

311. See infra text accompanying notes 481-482.

312. This has not gone unrecognized. See, e.g., Bob Dole, Shaping America's Global Future, Foreign Pol'y, Spring 1995, 28, 36 ("International organizations-whether the United Nations, the World Trade Organization, or any others-will not protect American interests. Only America can do that.”); see also infra text accompanying note 474 (discussing lack of exclusive accountability of international institutions to American people).

313. See generally Robert A. Dahl, How Democratic Is the American Constitution? (2002) [hereinafter Dahl, American Constitution] (explaining how U.S. Constitution falls short of providing an ideal basis for a democratic system).

314. Dahl, International Organizations, supra note 298, at 33; accord id. at 19, 32-33 ("Can international organizations, institutions, or processes be democratic? I argue that they cannot be.”). 
solicitude for the power of small states in the Senate, which may be compromised by delegations ${ }^{315}$ - may add to the case against delegation. ${ }^{316}$

Having already established the conceptual relevance of international delegations, however, it is also possible to consider other constitutional values as offsetting the welfarist and democratic cases against delegation. This follows, in my view, from the continued status of nondelegation as an underenforced constitutional norm. ${ }^{317}$ Even if the judiciary will not (and should not) enforce nondelegation as a categorical bar on international delegation, it still seems appropriate to balance nondelegation with other pertinent constitutional values. Put differently, if the value of underenforced norms may be balanced against the reasons for their underenforcement-such as the considerations counseling against judicial intervention, or the policy benefits of contravening the norm ${ }^{318}$ - and overcome by clearly stated expressions of congressional intent, ${ }^{319}$ they surely may be balanced against other constitutional values. ${ }^{320}$ For this reason, the relationship between international delegations and the U.S. states-not just as they function in the Senate, but in their larger role as

315. Manning, Canon of Avoidance, supra note 242, at 239-40 (summarizing argument).

316. Posner and Vermeule respond, predictably, that small states should not be particularly aggrieved, since they may block disadvantageous delegations, and influence the scope of agency discretion, to the same degree as with a nondelegating statute. Posner \& Vermeule, Interring, supra note 23 , at $1750-51$. Whatever the merits, the value in question is clearly distinct from the welfare and democratic concerns hitherto discussed. See Dahl, American Constitution, supra note 313, at 52-54, 85-86 (decrying antidemocratic influence of less populous states in the U.S. Senate); Lynn A. Baker \& Samuel H. Dinkin, The Senate: An Institution Whose Time Has Gone?, 13 J.L. \& Pol. 21 (1997) (considering impact of protecting smaller states); Ilya Somin, Closing the Pandora's Box of Federalism: The Case for Judicial Restriction of Federal Subsidies to State Governments, 90 Geo. L.J. 461 (2002) (citing counterproductive effects of disproportionate federal subsidies).

317. See supra Part II.B.

318. See Young, Constitutional Avoidance, supra note 17, at 1594-96 (describing "resistance norms," constitutional limits that may yield to other values).

319. See supra text accompanying notes 241-257 (discussing interpretive approaches to nondelegation).

320. Analogously, Hiroshi Motomura has defended the use of "phantom constitutional norms" to balance a plenary power doctrine applied by courts in immigration cases. See Motomura, supra note 17, at 564-65. The proposition defended here is considerably more modest. For one, the constitutional norm that might be overcome by the balance, unlike the plenary power in immigration law, is itself a "phantom" norm-namely, the moribund nondelegation doctrine. Second, courts would not be required to conduct the balancing, thus avoiding the delicate issues involved in that enterprise. Compare Crawford v. Washington, 124 S. Ct. 1354, 1373-74 (2004) (arguing, in Confrontation Clause context, against "replacing categorical constitutional guarantees" with "open-ended," "[v]ague," and "manipulable" balancing tests), with Washington v. Confederated Tribes of the Colville Indian Reservation, 447 U.S. 134, 177 (1980) (Rehnquist, J., concurring in part and dissenting in part) (arguing that, in determining immunity of Indian tribes from taxation, the judicial balancing was inappropriate "since it is that very balancing which we have reserved to Congress"). 
components of constitutional federalism-is worth more careful consideration, however it may cut.

\section{International Delegations and Constitutional Federalism}

Controversies involving delegations of executive or judicial authority seem to have a remote relationship with federalism: As the Supreme Court has implied, legislative choices to deprive the other branches of their rightful authority are not an issue in which the states have an obvious, immediate interest. ${ }^{321}$ Why isn't this equally true for legislative delegations? After all, the nondelegation doctrine nominally precludes congressional assignments of legislative power to the states as well ${ }^{322}$ - even, potentially, in cases when it may plausibly inure to the states' benefit. ${ }^{323}$

The first task, therefore, is to understand how federalism values may be implicated in international delegations. As with nondelegation, it then remains to assess whether federalism concerns are judicially enforceable-and, if not, whether they are nonetheless constitutional values worth preserving.

\section{A. The Apparent Relevance of Federalism}

Claims that international delegations compromise federalism are often put quite generally, making it difficult to determine whether the claim is really a broader one against each and every kind of international

321. See Commodity Futures Trading Comm'n v. Schor, 478 U.S. 833, 857 (1986) (noting that "prior [nondelegation] precedents . . . have dealt only with separation of powers concerns, and have not intimated that principles of federalism impose limits on Congress' ability to delegate adjudicative functions to non-Article III tribunals").

322. The Supreme Court, at least, has espoused that position. See, e.g., Knickerbocker Ice Co. v. Stewart, 253 U.S. 149, 164 (1920) ("Congress cannot transfer its legislative power to the states-by nature this is nondelegable.”); In re Rahrer, 140 U.S. 545, 560 (1891) ("Congress can neither delegate its own powers nor enlarge those of a State.”); see also Joshua D. Sarnoff, Cooperative Federalism, the Delegation of Federal Power, and the Constitution, 39 Ariz. L. Rev. 205, 270-77 (1997) (arguing that delegations to states and their equivalents should be considered unconstitutional). But see Ky. Div., Horsemen's Benevolent \& Protective Ass'n v. Turfway Park Racing Ass'n, 20 F.3d 1406, 1417 (6th Cir. 1994) (holding that "the separation of powers principle and, a fortiori, the nondelegation doctrine, simply are not implicated by Congress' 'delegation' of power to the States. Rather than violate the separation of powers principle, such a delegation in fact furthers another core constitutional value-that of federalism"); Krent, supra note 233, at 80-84, 94-112 (providing qualified defense of delegations to states in light of mechanisms for ensuring accountability and need to balance separation of powers concerns with state sovereignty).

323. The Supreme Court has held that the anticommandeering doctrine bars Congress from directing state officers or legislatures to enforce or comply with federal law-in the process rejecting arguments that such mechanisms in fact increase state autonomy relative to the alternative of maintaining exclusively federal control. See generally Printz v. United States, 521 U.S. 898 (1997); New York v. United States, 505 U.S. 144 (1992). There is good reason to think that the same goes for treaties. Swaine, Treaty Power, supra note 224, at 423-33; see also id. at 480-87 (noting limits to doctrine). 
engagement. ${ }^{324}$ Closer scrutiny suggests three ways that international delegations arguably offend constitutional, potentially constitutional, or subconstitutional visions of our federal system. ${ }^{325}$

1. The Aggregate Effect of International Delegations. - First, and most basically, international delegations may assign authority to international institutions that would otherwise have fallen to the states. Just as the increased integration of the U.S. economy and the perceived need for effective national administration promoted domestic delegations at the states' expense, ${ }^{326}$ so too globalization and the need for international regulatory harmonization drive the national government to allocate power internationally that might have been left local. The cumulative impact may be quite disruptive. As Thomas Franck remarked,

America's decentralized and divided constitutional scheme does not fit easily the exigencies of the growing system of supranational regimes. To the extent these regimes exercise actual powers-to regulate, arbitrate, enforce-these must have been devolved from somewhere else. To the extent that they come by subtraction either from the fifty states of the United States or from the representative political bodies of the Congress, there is bound to be serious concern among Americans: a concern based on the U.S. commitment both to direct political accountability and to decentralization of governance. ${ }^{327}$

\section{See supra note 16 (citing authorities).}

325. The distinctions (though not the precise labels) are drawn from David Shapiro, who notes that the Supreme Court has sometimes established absolute norms protecting state sovereignty, sometimes "strongly hinted" at federalism limitations when reaching dispositions on other grounds, and sometimes recognized significant state interests that may nevertheless be overcome by explicit, concerted national actions. David L. Shapiro, Federalism: A Dialogue 64-75 (1995).

326. See, e.g., Deborah Jones Merritt, The Guarantee Clause and State Autonomy: Federalism for a Third Century, 88 Colum. L. Rev. 1, 10 (1988) (linking the Court's abandonment of nondelegation to general expansion of federal regulatory authority at expense of states); Ernest A. Young, Two Cheers for Process Federalism, 46 Vill. L. Rev. 1349, 1363-64 (2001) (observing that "the most dramatic incursions on state regulatory authority" have followed the birth of the modern administrative state, and that " $[t]$ he judicial abandonment of the nondelegation doctrine, as well as the flowering of [federal common law], have both meant that federal lawmaking no longer need run the cumbersome gauntlet of Article I"); cf. Clark, supra note 212, at 1374 (observing that permitting delegation of legislative power would allow the federal government to "circumvent the lawmaking procedures established by the Constitution to implement the political safeguards of federalism and preserve the governance prerogatives of the states").

327. Franck, supra note 283, at 3-4; see also Lawrence J. Auerbach, Federalism in the Global Millennium, 26 Urb. Law. 235, 241 (1994) (describing globalization and centralization, "preemptive of local policies," as "mark[ing] a movement away from local control"); Curtis A. Bradley, The Treaty Power and American Federalism, 97 Mich. L. Rev. 390, 396-409 (1998) (describing emerging challenges to relationship between treaty power and federalism); Barry Friedman, Federalism's Future in the Global Village, 47 Vand. L. Rev. 1441, 1447-65, 1472 (1994) [hereinafter Friedman, Federalism's Future] 
To be clear, a substantial proportion of international harmonization has been accomplished directly by the national government and cannot fairly be attributed to international commitments, let alone to the exercise of authority by international institutions. ${ }^{328}$ But the states' fading authority over the banking and insurance industries, for example, has been accelerated by the General Agreement on Trade in Services (GATS). ${ }^{329}$ More important, although the United States carved out significant exemptions for the states at both the international and national levels, ${ }^{330}$ the WTO and NAFTA have nevertheless restricted state autonomy in regulating trade and investment, ${ }^{331}$ and even delegated authority to intervene in

(describing conflicts between international agreements and state regulatory authority, and concluding with prediction that "globalization will be the cause of a quite substantial curtailment of state authority"); Thomas O. Hueglin, New Wine in Old Bottles? Federalism and Nation States in the Twenty-First Century: A Conceptual Overview, in Rethinking Federalism: Citizens, Markets, and Governments in a Changing World 203, 220 (Karen Knop et al. eds., 1995) [hereinafter Rethinking Federalism] (describing tensions between international trade regulation and federalism); Robert Knowles, The Balance of Forces and the Empire of Liberty: States' Rights and the Louisiana Purchase, 88 Iowa L. Rev. 343, 418-19 (2003) (stating that "the treaty power still poses [a] threat to states' rights").

328. Yoo, Globalism and the Constitution, supra note 250, at 1969. But see id. (noting that shift to international regulation nonetheless "raises important questions of whether treaty power can supplant domestic lawmaking process"). State "blue sky" securities regulations, for example, lost some significance due to international harmonization. Friedman, Federalism's Future, supra note 327, at 1449-50; Robert Knowles, Note, Starbucks and the New Federalism: The Court's Answer to Globalization, 95 Nw. U. L. Rev. 735, 752 (2001). But greater change has been effected by international issuers' use of existing statutory market exemptions, and the greater risk has been federal preemption. See Mark A. Sargent, A Future for Blue Sky Law, 62 U. Cin. L. Rev. 471, 491 (1993) (describing states as "mostly irrelevant" in regulation of global securities market since international issuers easily qualify for state exemption).

329. General Agreement on Trade in Services, Apr. 15, 1994, WTO Agreement, Annex 1B, Uruguay Round of Multilateral Trade Negotiations: Legal Instruments Embodying the Results of the Uruguay Round of Multilateral Trade Negotiations Done at Marrakesh on 15 April 1994, vol. 28, at 22,595 (1994), 33 I.L.M. 1168 (1994).

330. See, e.g., Uruguay Round Agreements Act of 1994, 19 U.S.C. $\$ 3512$ (b) (2), (c) (entitling U.S. government alone to challenge federal or state action or inaction based on its consistency with the Uruguay Round Agreements); id. §3512(b)(1) (establishing consultation process to improve state compliance with international obligations, but also requiring that the U.S. Trade Representative take state positions into account, and enhancing state involvement with the dispute resolution proceedings that directly or indirectly affect state interests); The Uruguay Round Agreements Act: Statement of Administrative Action, attached to H.R. Rep. No. 103-826, pt. 1, at 656 (1994), reprinted in 1994 U.S.C.C.A.N. 4040, 4054-55; id., 1994 U.S.C.C.A.N. at 4050-54. Similar, if less elaborate, provisions are applicable to NAFTA. 19 U.S.C. $\$ 3312$ (b) (1); H.R. Rep. No. 103361, pt. 1, at 18 (1993), reprinted in 1993 U.S.C.C.A.N. 2552, 2569-70; see also Swaine, Treaty Power, supra note 224, at 420-21 (describing statutory provisions, statements of administrative action, and international exemptions).

331. See, e.g., Friedman, Federalism's Future, supra note 327, at 1453-64. 
such formerly sacrosanct areas as government procurement ${ }^{332}$ and alcohol, ${ }^{333}$ among others. ${ }^{334}$

As a political matter, the cost has been keenly felt: The North Dakota Attorney General spoke for many of her peers in opining that "'NAFTA and other trade agreements present the greatest challenge to state sovereignty that we have." 335 As a legal matter, though, it is less clear whether the volume of crumbs falling from the federal table is constitutionally significant, and how any constitutional objection may be

332. Agreement on Government Procurement, Apr. 15, 1994, Marrakesh Agreement Establishing the World Trade Organization, Annex 4, at 17-43, reprinted in Uruguay Round of Multilateral Trade Negotiations: Legal Instruments Embodying the Results of the Uruguay Round of Multilateral Trade Negotiations Done at Marrakesh on 15 April 1994, vol. 31, at 25,679-705 (1994); see also Sarah H. Cleveland, Crosby and the "OneVoice" Myth in U.S. Foreign Relations, 46 Vill. L. Rev. 975, 1005-06 (2001) (noting that " $[t]$ he WTO Government Procurement Agreement, in particular, raised the potential for conflict with the exercise of traditional state authority," but recognizing protective measures taken to respect that sovereignty); cf. Reeves, Inc. v. Stake, 447 U.S. 429, 438 n.10 (1980) (emphasizing, in articulating market participant exception to dormant Commerce Clause, state "sovereign interest in retaining freedom to decide how, with whom, and for whose benefit to deal").

333. GATT Report on Alcoholic Beverages, supra note 198, at 206 (holding state measures governing taxation, marketing, and distribution of alcohol incompatible with GATT); 140 Cong. Rec. 16,317 (1994) (remarks of Sen. Helms) (asserting that " [ $\mathrm{t}$ ] he Beer II panel struck at the very heart of federalism,'” since its reasoning "'leaves all State law potentially at risk of being subject to challenge under the aegis of GATT" " quoting Federation of Tax Administrators and Multistate Tax Commission)); Friedman, Federalism's Future, supra note 327, at 1461-62 (suggesting that Beer II decision impinged upon "special prerogative" of the states).

334. Counterexamples may be cited, too. It was feared, for example, that the WTO panels would make significant inroads into state taxing authority. E.g., 140 Cong. Rec. 16,308-310 (1994) (citing testimony of Dan R. Bucks, Executive Director of the Multistate Tax Commission); see Friedman, Federalism's Future, supra note 327, at 1462-63 (predicting that state taxes "are likely to come under increasing scrutiny" due to international trade agreements). What emerged, however, was less threatening. United States of America, Final List of Article II (MFN) Exemptions 9-10, GATS/EL/90 (Apr. 15, 1994), available at http://docsonline.wto.org/DDFDocuments/t/SCHD/GATS-EL/EL90. WPF (on file with the Columbia Law Review).

335. Evelyn Iritani, Trade Pacts Accused of Subverting U.S. Policies, L.A. Times, Feb. 28, 1999, at A1 (quoting Heidi Heitkamp, Attorney General, North Dakota); see also Carter Dougherty, Localities Eye Global Trade Role, Wash. Times, May 7, 2002, at C08, 2002 WL 2910098 (quoting California State Senator Sheila Kuehl as remarking that "[i]t seemed to me that practically everything we do could be challenged under NAFTA"). The feeling is shared by some at the national level. See, e.g., Withdrawing the Approval of the United States from the Agreement Establishing the World Trade Organization, H.J. Res. 90, 106th Cong. (2000), 146 Cong. Rec. H4787, H4800 (daily ed. June 21, 2000) (statement of Rep. Kucinich) (objecting that the Constitution "put the Congress . . . in charge of trade, and does not give [it] the right to cede that to an international body which . . . imposes obligations on State and local governments" limiting their regulatory authority); 144 Cong. Rec. H7278 (daily ed. Aug. 5, 1998) (statement of Rep. Bonior) ("No trade agreement should undermine the values that we have fought so hard for . . . at the State and at the local level."); 144 Cong. Rec. H7279 (daily ed. Aug. 5, 1998) (statement of Rep. Ros-Lehtinen) (commenting that because of WTO agreements, "the constitutional foundation for the role of States as laboratories of democracies . . . are in jeopardy"). 
made salient. Absent convincing evidence that an incremental loss of responsibility - as opposed to the general drift of authority, which may be relevant taken as a whole 336 _threatens the constitutional structure, it is difficult to envision this as a decisive objection to any particular delegation.

2. State Priority over International Delegations. - A second, distinct claim would be that the states are privileged by the Constitution to seize regulatory ground that Congress could, but has not, exploited. Reversions to the states are permissible under dormant Commerce Clause case law, ${ }^{337}$ but any privileged position would have to rely on other grounds. If the Supreme Court has not already thrown in the towel by declaring the Tenth Amendment to be a truism or tautology 338 — not, presumably, the ideal interpretive result-this position might be inferred from the Amendment's stipulation that " $[\mathrm{t}]$ he powers not delegated to the United States by the Constitution, nor prohibited by it to the States, are reserved to the States respectively, or to the people,"339 or perhaps from atmos-

336. See, e.g., Greve, Real Federalism, supra note 16, at 18-19 (describing expanded use of national government's regulatory authority as risking death of constitutional federalism); Robert F. Nagel, The Implosion of American Federalism (2001) (same); Ernest A. Young, State Sovereign Immunity and the Future of Federalism, 1999 Sup. Ct. Rev. 1, 3 ("The greatest danger to federalism, therefore, is that the expanding regulatory concerns of the national government will leave the states with nothing to do.").

337. See White v. Mass. Council of Constr. Employers, 460 U.S. 204, 213 (1983) ("Where state or local government action is specifically authorized by Congress, it is not subject to the Commerce Clause even if it interferes with interstate commerce."); Pike v. Bruce Church, Inc., 397 U.S. 137, 142 (1970) (explaining that states may regulate matters touching on interstate commerce " $[\mathrm{w}]$ here the statute regulates even-handedly to effectuate a legitimate local public interest, and its effects on interstate commerce are only incidental,... . unless the burden imposed on such commerce is clearly excessive in relation to the putative local benefits").

338. New York v. United States, 505 U.S. 144, 156 (1992) (citing "sense" in which "the Tenth Amendment "states but a truism that all is retained which has not been surrendered"' (quoting United States v. Darby, 312 U.S. 100, 124 (1941))); id. at 156-57 (describing Tenth Amendment as "essentially a tautology"). Although describing the Amendment as tautological seems inconsistent with the idea that the Tenth Amendment privileges the states relative to international institutions, that characterization directly addressed only the question of whether authority was initially assigned to the federal government or to the states. Id. at 156 (reciting "mirror image" inquiries, by which "[i]f a power is delegated to Congress in the Constitution, the Tenth Amendment expressly disclaims any reservation of that power to the States; if a power is an attribute of state sovereignty reserved by the Tenth Amendment, it is necessarily a power the Constitution has not conferred on Congress").

339. U.S. Const. amend. X. The inference of a privilege is hardly manifest; the text does not refer to what happens when power delegated to the United States is unexercised, and the powers "reserved" to the states seem to be those that the federal government could not exercise, rather than those that it did not exploit. But others have made the inference. See, e.g., Calvin R. Massey, State Sovereignty and the Tenth and Eleventh Amendments, 56 U. Chi. L. Rev. 61, 73 (1989) (explaining that, following Garcia v. San Antonio Metropolitan Transit Authority, 469 U.S. 528 (1985), "[t]he Tenth Amendment is treated as a statement that states possess residual sovereign powers, but the extent of those 
pheric invocations of the states' "residuary and inviolable sovereignty." 340 As the Court remarked nearer the heyday of nondelegation doctrine,

Under our constitutional system, there necessarily remains to the States, until Congress acts, a wide range for the permissible exercise of power appropriate to their territorial jurisdiction although interstate commerce may be affected. States are thus enabled to deal with local exigencies and to exert in the absence of conflict with federal legislation an essential protective power. ${ }^{341}$

On this theory, then, international delegations violate the Constitution not merely because the loss of residual authority risks upsetting the federal structure, but also because the states get dibs-consistent with the dormant Commerce Clause, and other constitutional constraints-on that residual authority. This principle is reflected, arguably, in the federalism RUDs sometimes attached to U.S. treaties and agreements. ${ }^{342}$ These RUDs have been criticized as unnecessary, given the expansive scope of national authority, ${ }^{343}$ but they tend to define a pecking order between the states and international institutions with a pretense to legislative capacity. ${ }^{344}$

sovereign powers is measured by the area left for state action after Congress has validly exercised its delegated powers").

340. The Federalist No. 39, at 245 (James Madison) (Clinton Rossiter ed., 1961); see Alden v. Maine, 527 U.S. 706, 715 (1999) (stating that the states "are not relegated to the role of mere provinces or political corporations, but retain the dignity, though not the full authority, of sovereignty").

341. Kelly v. Washington, 302 U.S. 1, 9-10 (1937) (emphasis added) (citation omitted); accord Breard v. City of Alexandria, 341 U.S. 622, 634 (1951) (emphasizing state power cited in Kelly).

342. See, e.g., Senate Resolution of Advice and Consent to Ratification of the International Covenant on Civil and Political Rights, 102d Cong., 138 Cong. Rec. 8071 (1992) (" $[T]$ he United States understands that this Covenant shall be implemented by the Federal Government to the extent that it exercises legislative and judicial jurisdiction over the matters covered therein, and otherwise by the state and local governments."); Comm. on Foreign Relations, Report on International Covenant on Civil and Political Rights, S. Exec. Rep. No. 102-23, at 18 (1992) (explaining that the federalism understanding "serves to emphasize domestically that there is no intent to alter the constitutional balance of authority between the State and Federal governments or to use the provisions of the Covenant to 'federalize' matters now within the competence of the States"). For other examples of federalism RUDs, see U.S. Senate Resolution of Advice and Consent to Ratification of the Convention on the Elimination of All Forms of Racial Discrimination, 103d Cong., 140 Cong. Rec. 14,326 (1994); U.S. Senate Resolution of Advice and Consent to Ratification of the Convention Against Torture and Other Cruel, Inhuman or Degrading Treatment or Punishment, 101st Cong., 136 Cong. Rec. 36,192 (1990).

343. See Bradley \& Goldsmith, Treaties, supra note 65 , at 422, 454-55 (noting and addressing criticism).

344. They are not ubiquitous, however, nor do they abrogate the ability of those institutions to usurp rulemaking ability-as their use in connection with the ILO and recent trade agreements indicate. The latter provisions, at least, give states a substantial 
3. International Delegations as an Affront to State Sovereignty. - A final theory is that assigning authority to international institutions, rather than retaining it for use by Congress, is more offensive to state sovereignty. Articulating this argument is difficult, not least because it relies on murky, expressivist notions like the "sovereignty"345 and "dignity"346 of states. ${ }^{347}$ Such a claim may be gleaned, however, from the significance placed by the Constitution on "affording national protection to the states against outside intrusion," 348 as well as from recent case law rejecting attempted incursions by the national government, whether in pursuit of its

voice in the process of their application. See Swaine, Treaty Power, supra note 224, at 420-21 \& nn.71-72 (describing procedures relating to state authority in NAFTA and the Uruguay Round implementing statutes). The ILO clause, however, places the determination as to whether an ILO-governed matter is "appropriate" for state implementation in the discretion of the federal government. ILO Constitution, supra note 31, art. 19(7), 62 Stat. at 3526, 15 U.N.T.S. at 76; Robert B. Looper, 'Federal State' Clauses in Multilateral Instruments, 32 Brit. Y.B. Int'l L. 162, 167, 182-84 (1955-1956) (discussing ILO clause); see also Ivan Bernier, International Legal Aspects of Federalism 175-80 (1973) (discussing ILO clause and other instances of federal-state clauses subject to interpretation by national governments).

345. Nonlegal academics, in particular, tend to find this usage ridiculous. See, e.g., Jack N. Rakove, Making a Hash of Sovereignty, Part I, 2 Green Bag 2d 35, 41-44 (1998) (concluding that traditional concept of state sovereignty, which emphasized its unitary and absolute nature, has little descriptive value in making sense of the federal system); Jack N. Rakove, Making a Hash of Sovereignty, Part II, 3 Green Bag 2d 51, 57-59 (1999) ("Sovereignty is too vague and anachronistic a term to allow us to reason about anything more than our propensity to keep using it.").

346. For representative criticisms of this rhetoric, see Ann Althouse, Lecture, On Dignity and Deference: The Supreme Court's New Federalism, 68 U. Cin. L. Rev. 245, 249-56 (2000); Suzanna Sherry, States Are People Too, 75 Notre Dame L. Rev. 1121 (2000). For cautious endorsements, see Evan H. Caminker, Judicial Solicitude for State Dignity, 574 Annals Am. Acad. Pol. \& Soc. Sci. 81, 84-89 (2001); Judith Resnik \& Julie Chihye Suk, Adding Insult to Injury: Questioning the Role of Dignity in Conceptions of Sovereignty, 55 Stan. L. Rev. 1921 (2003).

347. Expressivism takes a maddening variety of forms, but is used here to connote a theory that "tell[s] actors ... to act in ways that express appropriate attitudes toward various substantive values." Elizabeth S. Anderson \& Richard H. Pildes, Expressive Theories of Law: A General Restatement, 148 U. Pa. L. Rev. 1503, 1504 (2000). For debate over analogous values relating to anticommandeering doctrine, compare id. at 1556-64 (rationalizing anticommandeering rule on expressive grounds), and Adam B. Cox, Expressivism in Federalism: A New Defense of the Anti-Commandeering Rule?, 33 Loy. L.A. L. Rev. 1309, 1316-20 (2000) (outlining expressive defense of anticommandeering rule), with Matthew D. Adler \& Seth F. Kreimer, The New Etiquette of Federalism: New York, Printz, and Yeskey, 1998 Sup. Ct. Rev. 71, 133-40 (skeptically evaluating expressive defense of anticommandeering).

348. Shapiro, supra note 325, at 60. Professor Shapiro cites Article IV of the Constitution in general, but also adverts to the obligation of the national government to protect states against invasion by other states. See U.S. Const. art. IV, § 3; see also Joseph F. Zimmerman, Contemporary American Federalism: The Growth of National Power 19-23 (1992) (describing five constitutional "[n]ational guarantees" to the states, including guarantee of territorial integrity under Article IV). 
own regulatory interests ${ }^{349}$ or in its attempts to enable others who might challenge the states. ${ }^{350}$

Even if notions like sovereignty and dignity are of little help in distinguishing between acceptable and unacceptable incursions, these cases arguably communicate some kind of hierarchy. The Supreme Court's allusions to state dignity sometimes seem to draw on the dignity afforded foreign nations, ${ }^{351}$ but the differences are also evident. Under Principality of Monaco v. Mississippi, states are immune from suits brought by foreign nations, notwithstanding the text of the Eleventh Amendment; ${ }^{352}$ according to the Court, while states agreed to be vulnerable to one another's sovereign claims, and to those of the United States, foreign nations were "outside the structure of the Union" and not part of the same bargain. ${ }^{353}$ The states were not, in practice, on par with the federal government, which enjoyed an asymmetric ability to sue them. ${ }^{354}$ But Congress was denied the authority to abrogate state sovereign immunity on behalf of

349. See, e.g., New York v. United States, 505 U.S. 144, 157 (1992) (concluding that " $[t]$ he Tenth Amendment thus directs us to determine, as in this case, whether an incident of state sovereignty is protected by a limitation on an Article I power").

350. See, e.g., Fed. Mar. Comm'n v. S.C. Ports Auth., 535 U.S. 743, 769 (2002) (asserting that "the primary function of sovereign immunity is not to protect state treasuries . . . but to afford the States the dignity and respect due sovereign entities"); Alden v. Maine, 527 U.S. 706, 714 (1999) (explaining that the federal system established by the Constitution "reserves to [the states] a substantial portion of the Nation's primary sovereignty, together with the dignity and essential attributes inhering in that status," such that "[ $\mathrm{t}]$ he States 'form distinct and independent portions of the supremacy, no more subject, within their respective spheres, to the general authority than the general authority is subject to them, within its own sphere" " (quoting The Federalist No. 39, supra note 340, at 245 (James Madison))); Resnik \& Suk, supra note 346, at $1923 \mathrm{n} .9$ (citing additional examples). Peter Smith recently traced the emphasis on dignity in the sovereign immunity cases to the Court's decision in Puerto Rico Aqueduct \& Sewer Authority v. Metcalf \& Eddy, Inc., 506 U.S. 139, 146 (1993). Peter J. Smith, States as Nations: Dignity in CrossDoctrinal Perspective, 89 Va. L. Rev. 1, 11-14 (2003).

351. See, e.g., Vt. Agency of Natural Res. v. United States ex rel. Stevens, 529 U.S. 765, 780 n.9 (2000) ("While the States do not have the immunity against federally authorized suit that international law has traditionally accorded foreign sovereigns, they are sovereigns nonetheless, [worthy of the] comity and respect [due] our federal system." (citations omitted)). See generally Smith, supra note 350, at 6-9, 27-28, 76-80 (tracing notion of dignity in state sovereign immunity case law to foreign state sovereign immunity doctrine and law of nations).

352. 292 U.S. 313, 329-30 (1934); see U.S. Const. amend. XI (foreclosing extension of judicial power to "any suit in law or equity, commenced or prosecuted against one of the United States by Citizens of another State, or by Citizens or Subjects of any Foreign State." (emphasis added)); Thomas H. Lee, Making Sense of the Eleventh Amendment: International Law and State Sovereignty, 96 Nw. U. L. Rev. 1027, 1046-47, 1089-90 (2002) (justifying literal approach to the Eleventh Amendment based on analogy to immunity of foreign nations to suit by citizens of foreign nations, but decrying the deviation represented by Principality of Monaco).

353. Principality of Monaco, 292 U.S. at 330.

354. See Kansas v. United States, 204 U.S. 331, 342 (1907) ("It does not follow that because a State may be sued by the United States without its consent, therefore the United States may be sued by a State without its consent. Public policy forbids that conclusion."). 
others, including foreign nations, with the same ease as it might waive foreign sovereign immunity. ${ }^{355}$

The analogy to international delegations, then, would be as follows: While the sovereign states acquiesced to a system in which regulatory authority would be exercised by the United States, and in which their authority over political and economic issues could be ousted, they did not so defer to foreign nations or international institutions. Just as the Eleventh Amendment clarified that Congress lacked the right to privilege outsiders (be they citizens of other states, or foreign nations) to take liberties with the states, so too a restored nondelegation doctrine would prohibit delegations to international institutions that privileged outsiders to interfere with state sovereign prerogatives.

Such dignitary offenses would be still more acute, presumably, if international delegations encroached on traditional state prerogatives. The potential for such occasions is evident. A Canadian company, for example, challenged a state statute conferring immunity on the Boston Redevelopment Authority as incompatible with the national treatment obligation under NAFTA, although the panel determined that NAFTA did not apply retroactively to the dispute in question. ${ }^{356}$ Another (formerly) Canadian firm challenged an enormous punitive damages award rendered by a Mississippi jury; while that panel, too, stopped short of deciding the merits, ${ }^{357}$ it volunteered that the trial and verdict "cannot be squared with minimum standards of international law and fair and equitable treatment" 358 - this in an area that the Supreme Court has determined is primarily for the states to govern autonomously. ${ }^{359}$

355. Smith, supra note 350, at 98-99. Compare Coll. Sav. Bank v. Fla. Prepaid Postsecondary Educ. Expense Bd., 527 U.S. 666, 675 (1999) (holding that abrogation of immunity in Trademark Remedy Clarification Act could not be sustained under the Fourteenth Amendment), and Fla. Prepaid Postsecondary Educ. Expense Bd. v. Coll. Sav. Bank, 527 U.S. 627, 636, 647 (1999) (holding that Congress lacked authority under Article I to abrogate state sovereign immunity in the Patent and Plant Variety Protection Remedy Clarification Act, and had not established an adequate basis under the Fourteenth Amendment), with Foreign Sovereign Immunities Act, 28 U.S.C. § 1605 (2000) (implementing restrictive view of foreign sovereign immunity, and waiving immunity for certain classes of claims).

356. Mondev Int'l Ltd. v. United States, Award, ICSID Case No. ARB(AF) $/ 99 / 2$, II I 66-75 (NAFTA Ch. 11 Arb. Trib. 2002), available at http://www.state.gov/documents/ organization/14442.pdf (on file with the Columbia Law Review).

357. Loewen Group v. United States, Award, ICSID Case No. ARB(AF)/98/3, II 217, 234, 42 I.L.M. 811, 846, 849 (NAFTA Ch. 11 Arb. Trib. 2003) (concluding that firm's reorganization as a U.S. firm after bankruptcy, plus its failure to exhaust local remedies, insulated Mississippi proceedings from review).

358. Id. I 137, 42 I.L.M. at 833.

359. Id. (describing fear by one commentator that the Loewen dicta will become "the dicta that ate NAFTA"); see State Farm Mut. Auto Ins. Co. v. Campbell, 538 U.S. 408, 422 (2003) ("A basic principle of federalism is that . . . each State alone can determine what measure of punishment, if any, to impose on a defendant who acts within its jurisdiction."); see also Silkwood v. Kerr-McGee Corp., 464 U.S. 238, 255 (1984) ("Punitive damages have long been a part of traditional state tort law."). In State Farm itself, this "basic principle" 
$* * *$

Collectively, the arguments that international delegations injure federalism are at least colorable. None, notably, have set out any normative warrants for preserving federalism (or elaborated why the states are the best guarantors of federalism values), nor have they provided any robust explanation as to why the national political process would fail to protect the states against any severe incursions. ${ }^{360}$ For some concerned about international delegations, though, the answer to the latter question seems obvious: The delegation of authority to international institutions risks supplanting national governments. ${ }^{361}$ National sovereigns, it is argued, are losing control, which in turn imperils federalism's existing political safeguards. If institutions like the NAFTA tribunals threatened "[f] undamental exercises of self-government" before Congress was pressured into intervening, ${ }^{362}$ those who would preserve federalism may legitimately be concerned as to how matters might otherwise have looked.

\section{B. Federalism as an Underenforced Norm}

The judiciary has been slow to respond to the risks delegations pose to federalism. As previously noted, the nondelegation doctrine nominally operates to prevent delegation of congressional power to the states, while at the same time preserving state authority by cabining the exercise of national power. Nonetheless, the strongest link between nondelegation and federalism is that neither is fully enforced by the Supreme Court. ${ }^{363}$ To be sure, the Rehnquist Court's enthusiasm for federalism is

was at risk where a state might punish a defendant for out-of-state conduct-that is, where punitive damages might infringe on another state's prerogatives, 538 U.S. at 421-22-but this, too, is an attribute of federalism.

360. See Swaine, Treaty Power, supra note 224, at 443-44 (evaluating sufficiency of political safeguards in treatymaking for protecting state interests). For samples of the broader disagreement, compare Larry D. Kramer, Putting the Politics Back into the Political Safeguards of Federalism, 100 Colum. L. Rev. 215, 219 (2000) (describing political safeguards claims, and adding emphasis on political parties), with Lynn A. Baker, Putting the Safeguards Back into the Political Safeguards of Federalism, 46 Vill. L. Rev. 951 (2001) (disputing sufficiency of political safeguards), and Saikrishna B. Prakash \& John C. Yoo, The Puzzling Persistence of Process-Based Federalism Theories, 79 Tex. L. Rev. 1459 (2001) (same).

361. See supra text accompanying notes 10-14.

362. Michelle Sager, One Voice or Many? Federalism and International Trade 94 (2002) [hereinafter Sager, One Voice] (quoting The Impact of NAFTA on the Public Sector: Hearing Before the Legis. and Nat'l Sec. Subcomm. of the Comm. on Gov't Operations, 103d Cong. 142 (1994) (statement of Max B. Sawicky, Economic Policy Institute)). Sager's book is the best succinct account of the political struggles between the states and the federal government regarding NAFTA. See id. ch. 4.

363. See Lynn A. Baker \& Ernest A. Young, Federalism and the Double Standard of Judicial Review, 51 Duke L.J. 75, 75-76 (2001) (describing “federalism's historic link to other aspects of our expatriate constitution-e.g., economic substantive due process, legislative nondelegation-which were banished for their collusion”). 
patent, ${ }^{364}$ and it has reneged on indications that the Justices would step out of policing federalism altogether. ${ }^{365}$ But the Court has remained reluctant to enforce additional limitations based on reserved areas of exclusive state authority, if Congress is otherwise acting within its Article I competence. ${ }^{366}$ In part because of concerns regarding judicial competence, ${ }^{367}$ the Court has taken the view that national political processes are the principal safeguard against such incursions ${ }^{368}$ _albeit a

364. See generally John T. Noonan, Jr., Narrowing the Nation's Power: The Supreme Court Sides with the States (2002) (suggesting revolution in federalism jurisprudence). While some queried whether the Court's "hostile" view of federal authority might change after September 11, see, e.g., Linda Greenhouse, Will the Court Reassert National Authority?, N.Y. Times, Sept. 30, 2001, 44 (Week in Review), at 14, the answer appears to have been in the negative. Linda Greenhouse, For a Supreme Court Graybeard, States' Rights Can Do No Wrong, N.Y. Times, Mar. 16, 2003, §4 (Week in Review), at 5 (concluding, in appraising Chief Justice Rehnquist's contributions, that "the federalism revolution he ignited was solidly underway and is likely to define his place in Supreme Court history").

365. Garcia v. San Antonio Metro. Transit Auth., 469 U.S. 528, 530-31 (1985) (overruling National League of Cities v. Usery, 426 U.S. 833 (1976), which itself overruled Maryland v. Wirtz, 392 U.S. 183 (1968)); compare Rubin \& Feeley, supra note 24, at 903 (construing the Supreme Court's decision in Garcia as a "brave declaration that it had sworn off federalism for good"), with John C. Yoo, The Judicial Safeguards of Federalism, 70 S. Cal. L. Rev. 1311, 1311-12 (1997) (arguing that, if Garcia is considered to have announced that "it no longer would examine the constitutionality of federal legislation that threatened to violate the sovereignty of the states," it is no longer good law).

366. See Ernest A. Young, Is the Sky Falling on the Federal Government? State Sovereign Immunity, the Section Five Power, and the Federal Balance, 81 Tex. L. Rev. 1551, 1572 n.122 (2003) (making this distinction). To be sure, the Supreme Court has revived the rhetoric of "dual sovereignty," which was originally associated with the notion that the states retain " 'a residuary and inviolable sovereignty.'” Printz v. United States, 521 U.S. 898, 918-19 (1997) (quoting The Federalist No. 39, supra note 340, at 245 (James Madison)). But while the Court increasingly treats state sovereign immunity and other attributes of state dignity as "inviolable" in character, it explicitly regards the states' retention of government authority as only "residuary"-what is left, that is, after the enforcement of limits on Congress's authority under Article I and the Fourteenth Amendment. Id. Dual federalism, in the classic sense of connoting an exclusive field of regulation for the states, see Edward S. Corwin, The Commerce Power Versus States Rights 135 (1936) (describing dual federalism as "the theory of two mutually exclusive, reciprocally limiting fields of power, the governmental occupants of which confront each other as equals"), has not been revived, and may be beyond reviving, see Edward S. Corwin, The Passing of Dual Federalism, 36 Va. L. Rev. 1 (1950) (describing alteration of constitutional structure); Richard E. Levy, Federalism: The Next Generation, 33 Loy. L.A. L. Rev. 1629, 1638-45 (2000) (describing how recent Supreme Court cases sketched Commerce Clause limits and restricted means for congressional action, without protecting against use of other federal powers); Robert Post, Federalism in the Taft Court Era: Can It Be "Revived"?, 51 Duke L.J. 1513, 1638-39 (2002) (explaining why the Rehnquist Court's case law has not, and cannot, revive dual federalism).

367. See Garcia, 469 U.S. at 548 ("We doubt that courts ultimately can identify principled constitutional limitations on the scope of Congress' Commerce Clause powers over the States merely by relying on a priori definitions of state sovereignty.").

368 . See id. at 552 ("State sovereign interests . . . are more properly protected by procedural safeguards inherent in the structure of the federal system than by judicially created limitations on federal power."). 
safeguard protected by the narrowing constructions recently given the Commerce Clause and the Fourteenth Amendment, the bar on "commandeering" states, and the limits to waivers of state sovereign immunity. ${ }^{369}$

The gap between the nominal scope of federalism doctrine and its judicial enforcement has caused the resort to familiar alternatives, including canons favoring construing statutes so as to avoid infringements on state sovereignty. ${ }^{370}$ Irrespective of whether these canons close the underenforcement gap in the domestic setting, they have had little effect in foreign affairs, where they confront contrary presumptions favoring national authority. ${ }^{371}$ There, the conventional wisdom is that states have even less, if any, reserved authority, given that the national government's treaty power is complemented by a bar on state agreements with foreign powers. ${ }^{372}$ The Supreme Court's recent decision in American Insurance Ass'n v. Garamendi, while disclaiming any general resolution of preemption in foreign affairs, indicated that anything more than an incidental effect on national policy may warrant preemption, and suggested that whether a state acts in an area of traditional competence is at best a preliminary, rather than a conclusive, inquiry. ${ }^{373}$

As with the nondelegation doctrine, it is difficult to determine whether the federalism doctrine's underenforcement in foreign affairs reflects its renunciation on the merits or, alternatively, a judicial reluctance to intervene. The most plausible answer is that both the merits and justiciability are involved, and will continue to be. The Supreme Court's recent refusal to revive any dormant foreign affairs preemption power suggests that it is not yet willing to renounce any accommodation of the states in international affairs, ${ }^{374}$ indeed, given claims that international institutions undermine state prerogatives regarding formerly domestic affairs, doing so would seemingly be both unmanageable and fraught with

369. See Young, Constitutional Avoidance, supra note 17, at 1604 n.281 (suggesting that federalism may be underenforced, notwithstanding recent decisions protecting state sovereignty).

370. See Shapiro, supra note 325, at 71-75 (briefly surveying field); Einer Elhauge, Preference-Eliciting Statutory Default Rules, 102 Colum. L. Rev. 2162, 2251-52 (2002) (attributing aggressive avoidance of constructions infringing on federalism values to the Supreme Court's inability "to develop intelligible rules to provide content to the Tenth Amendment").

371. See Jack L. Goldsmith, Statutory Foreign Affairs Preemption, 2000 S. Ct. Rev. 175, 195-201 (describing tension between presumptions); see also Edward T. Swaine, The Undersea World of Foreign Relations Federalism, 2 Chi. J. Int'l L. 337, 347-51 (2001) (commenting on Goldsmith).

372. Swaine, Negotiating Federalism, supra note 221, at 1129 n.1 (citing commentary). I have elsewhere argued that these provisions can be mediated, but it is at Congress's discretion. See generally Swaine, Treaty Power, supra note 224.

373. 539 U.S. 396, 418-20 (2003); id. at 424-25 (emphasizing nontraditional, and thus weak, state interest for purposes of assessing conflict with federal policy).

374. See supra note 241 (describing resolution of Zschernig v. Miller claim in Garamendi). 
hazard. ${ }^{375}$ The result, then, is that colorable concerns about federalism, supported by case law, nonetheless find little succor in the courts.

\section{The Continuing Salience of Federalism}

I have assumed to this point that any harm international delegations cause to federalism is worth preventing, notwithstanding any judicial reluctance to intervene. But what if that assumption is misplaced? Just as Posner and Vermeule attempt the evisceration of the nondelegation doctrine on its merits, others contend that federalism isn't worth protecting in the first place. ${ }^{376}$ Unlike Posner and Vermeule, these critics do not specifically address the subject of international delegations. Still, if federalism is a distraction, as critics report, it should have little bearing on the constitutionality of those delegations.

The central insight, winningly articulated by Edward Rubin and Malcolm Feeley, is that many of the claimed virtues of federalism-particularly public participation, the virtues of jurisdictional competition, and the "laboratories of democracy"-are better attributed to decentralization. Unfettered federalism, which allows states autonomy in certain policy areas, tends to produce chaotic variation that would have to be prized for its own sake. Only centrally managed decentralization, they submit, offers a genuine chance to realize the virtues falsely associated with federalism. ${ }^{377}$

375. Cf. Swaine, Negotiating Federalism, supra note 221, at 1236-42 (evaluating claims that merger of domestic and foreign affairs has changed constitutional restrictions on state diplomacy).

376. See, e.g., Rubin \& Feeley, supra note 24, at 909 (endorsing Garcia holding not on grounds "that the states are capable of protecting themselves," but rather on grounds "that there is no normative principle involved that is worthy of protection").

377. As they explain,

[M] any standard arguments advanced for federalism are clearly nothing more than policy arguments for decentralization. These are the claims that some nationally-defined policy is best achieved by permitting regional variation. The point is not simply that federalism is unnecessary for implementing such policies, that it represents an unnecessary use of constitutional artillery. Rather, federalism is absolutely antithetical to these policies because it allows the wrong kinds of variation. Implementing a national policy through a decentralized system means that the permitted variations will be those that contribute to achieving the designated policy. In contrast, federalism allows the states to vary as they choose, pursuing their own policies instead of the national one. This can be justified only by arguments favoring a variety of policies, not by arguments favoring the implementation of a single policy by a variety of methods.

Id. at 914; see also Akhil Reed Amar, Some New World Lessons for the Old World, 58 U. Chi. L. Rev. 483, 498 (1991) (stressing that "[w]e must not confuse federalism . . . with decentralization"); Andrzej Rapaczynski, From Sovereignty to Process: The Jurisprudence of Federalism After Garcia, 1985 Sup. Ct. Rev. 341, 390, 408-14 (explaining that central governments can capture the advantages of decentralization). 
Nonetheless, the fact that decentralization is not constitutional-and therefore might not be pursued-gives pause. ${ }^{378}$ Professors Rubin and Feeley allow that " $[c]$ oncern about the concentration of power was one of the guiding forces in the design of our entire political system," 379 and a key solution was the vertical division of authority: In Madison's words, dividing responsibility between "two distinct governments," together with the separation of powers, means that "[t]he different governments will control each other, at the same time that each will be controlled by itself." 380 To the Framers, the initial diffusion of authority, and the result-

378. Others have raised a slightly different criticism, namely, that today's federalism is the only kind of decentralization we have. See Barry Friedman, Valuing Federalism, 82 Minn. L. Rev. 317, 381-83 (1997); see also Vicki C. Jackson, Federalism and the Uses and Limits of Law: Printz and Principle?, 111 Harv. L. Rev. 2180, 2217-28 (1998) [hereinafter Jackson, Federalism] (noting importance of recognizing that "decentralization . . . is a function of, and bound up with, federalism"). Rubin and Feeley agree, insofar as they would not abolish the states, see Rubin \& Feeley, supra note 24, at 908-09 (noting that because relying on other subdivisions "would be costly and disruptive . . . it is probably best to use the existing states as our primary means of decentralization"), and would be content with some aspects of contemporary federalism as it is enforced by the courts, see id. at 909 (suggesting that Garcia v. San Antonio Metropolitan Transit Authority, 469 U.S. 528 (1985), be honored, so that "[t]he Supreme Court should never invoke federalism as a reason for invalidating a federal statute or as a principle for interpreting it").

379. Rubin \& Feeley, supra note 24, at 927; see also id. (describing diffusion as one "important argument[] that genuinely support[s] the basic principles of federalism"). The most credible concern, in their view, involves the aggregation of administrative power-"control over appointed officials, public resources, and regulatory rules"-as distinct from political power over "votes, offices, and public opinion." Id. at 931. They more readily dismiss, on the other hand, the need to disperse physical (military) power and the importance of ensuring separate political identities. Id. at 928-31. Were these values less readily disregarded, they might offer additional reasons to value constitutional federalism in its present form, though I share Rubin and Feeley's skepticism. The formal political identity of the states, as distinct from their practical authority, does not genuinely seem at stake. Id. at 929-30. As to physical power, one might disagree as to the potential utility of the states. Compare id. at 928-29 \& n.86 (arguing that state-level deterrence is no longer tenable, citing the federal government's nuclear superiority), with Amar, supra note 377, at 501-03 (1991) (discussing how federalism can help "address the worst-case scenario, in which a tyrannical government . . . attempts to rule by brute military force"). But it seems incontestable that the dispersion of authority through analogous international mechanisms is the more effective check. See infra text accompanying notes 402-412 (discussing U.N. Security Council).

380. The Federalist No. 51, supra note 340, at 323 (James Madison); see also The Federalist No. 28, supra note 340, at 180-81 (Alexander Hamilton) (explaining that federalism would thwart attempts at tyranny, since "[p] ower being almost always the rival of power, the general government will at all times stand ready to check the usurpations of the state governments, and these will have the same disposition towards the general government," and either may be made effective in accordance with the popular will). These arguments have been emphasized by the Supreme Court. See New York v. United States, 505 U.S. 144, 181 (1992) (observing that "federalism secures to citizens the liberties that derive from the diffusion of sovereign power" (quoting Coleman v. Thompson, 501 U.S. 722, 759 (1991) (Blackmun, J., dissenting))); Gregory v. Ashcroft, 501 U.S. 452, 458 (1991) ("Just as the separation and independence of the coordinate branches of the Federal Government serve to prevent the accumulation of excessive power 
ing benefits associated with decentralization, could be secured only by constitutionally guaranteeing an independent checking role for the states. ${ }^{381}$

The critical proposition here-that the national government would fail, if left to its own devices, to capture what federalism guarantees-is difficult to evaluate empirically, in no small part because the content of federalism's guarantees is open to dispute. ${ }^{382}$ But it seems doubtful that the national government has the right incentives to decentralize when it should. ${ }^{383}$ Central governments may be reluctant to share desirable au-

in any one branch, a healthy balance of power between the States and the Federal Government will reduce the risk of tyranny and abuse from either front.”).

381. See, e.g., Vincent Ostrom, The Meaning of American Federalism 91-92 (1991) (criticizing supposition that decentralized but unitary government would benevolently respect local authority, and citing Publius's concern regarding self-aggrandizing and oligarchical tendencies of a central government); Amar, supra note 377, at 498-99 (explaining Publius's vision that "healthy competition between federal and local officials can help protect citizens against government tyranny," and that " $[\mathrm{t}]$ he key to this dynamic is that each government must retain a certain degree of institutional autonomy-a measure of structural independence-from the other"); see also Calvin Massey, Federalism and the Rehnquist Court, 53 Hastings L.J. 431, 443-44 (2002) (summarizing role for federalism in thwarting dangerous concentrations of power).

382. Frank Cross has asserted, for example, that the national government presently decentralizes "far beyond any level required by constitutional federalism." Cross, supra note 24 , at 46 . The evidence of decentralization in fact appears mixed, and the future uncertain. See generally Timothy Conlan, From New Federalism to Devolution: TwentyFive Years of Intergovernmental Reform (1998) (tracing evolution of federalism and reform of American federal system); David B. Walker, The Rebirth of Federalism 171, 322-28 (2d ed. 2000) (noting mixed evidence regarding devolution of authority). More to the point, the assertion depends upon an assumption that the Constitution requires little decentralization, which remains to be established; were that assumption widely shared, moreover, the rate of such "voluntary" decentralization might slow considerably. See Jackson, Federalism, supra note 378, at 2217 (explaining that, since "present realities are conditioned by the existence of the states, and by a belief, shared by many, that [they] are constitutionally secured[,] . . . abandoning constitutional federalism has potentially high costs" (citation omitted)).

383. Bednar, Eskridge, and Ferejohn call this the problem of credible decentralization. Jenna Bednar et al., A Political Theory of Federalism, in Constitutional Culture and Democratic Rule 223, 224 (John Ferejohn et al. eds., 2001) ("[A]ll must believe that the regional governments will not try to take advantage of one another and that the center will not try to usurp power form the regions . . . an ideal that has proved elusive at times in each of the [case studies].”); see William Riker, Federalism: Origin, Operation, Significance 7-8 (1964) (describing tendency of central power in centralized federal systems to exert increasing pull and to "overawe" constituent units); Daniel J. Elazar, The United States and the European Union: Models for Their Epochs, in The Federal Vision: Legitimacy and Levels of Governance in the United States and the European Union 41 (Kalypso Nicolaidis \& Robert Howse eds., 2001) (stating that, absent a system that checks the central powers, "there would be no function that would not be seized by the larger, stronger government in the course of time"); see also Shapiro, supra note 325, at 137-39 (describing centripetal and centrifugal forces affecting distribution of political authority); Cary Coglianese \& Kalypso Nicolaidis, Securing Subsidiarity: The Institutional Design of Federalism in the United States and Europe, in The Federal Vision: Legitimacy and Levels of Governance in the United States and the European Union, supra, 
thority with the states (particularly if they are regarded as rivals for political allegiance) ${ }^{384}$ and overzealous in shuffling off relatively unrewarding tasks for the states to handle. ${ }^{385}$ Rent-seeking interest groups, too, will distort the central government's incentives for efficient decentralization. ${ }^{386}$ All things considered, it seems reasonable to suppose that decentralization is not entirely self-enforcing. ${ }^{387}$

at 277, 281 (describing federal and state incentives to renege on constitutional bargain); Clayton P. Gillette, The Exercise of Trumps by Decentralized Governments, 83 Va. L. Rev. 1347, 1349-50 (1997) (same).

In addition to lacking sufficient incentives, it is likely that the central government would lack sufficient information to coordinate effective decentralization. Ronald McKinnon \& Thomas Nechyba, Competition in Federal Systems: The Role of Political and Financial Constraints, in The New Federalism: Can the States be Trusted? 3, 10-11 (John A. Ferejohn \& Barry R. Weingast eds., 1997) (discussing information problems facing central governments that attempt to determine ideal provision of local services). And even if such information could be obtained, doing so may be costly, improving the relative efficiency of truer federalism. States, for their part, may act collusively, either among themselves or with the cooperation of the national government. Id. at 29-30. On some subjects, such as interstate commerce, the risks are sufficient that near-exclusive authority is given to the national government. McGinnis \& Movsesian, World Trade Constitution, supra note 284, at 536-42 (suggesting that "[n]ational representatives are more likely to rise above parochial interests than local representatives").

384. See, e.g., Baker \& Young, supra note 363, at 138 n.282 ("Unless states are endowed with 'trumps' that guarantee them some measure of sovereignty . . . federal politicians will be able to undermine their potential political opponents in the states by withdrawing meaningful functions from state governments.”); cf. Amar, supra note 377, at 503-05 (explaining how state governments have played a role within federalism "similar to that of the institutional press" by "monitoring the conduct of officials in power, and coordinating opposition to central policies deemed undesirable").

385. See, e.g., Paul E. Peterson, The Price of Federalism 180-81 (1995) (describing tendency of national politicians to leave intractable political problems to state and local officials).

386. There is an enormous literature on this subject. For a brief explanation of the dynamics, see McKinnon \& Nechyba, supra note 383, at 26-28 (outlining elements underlying centralization tensions between central and lower-tiered governments).

387. In a valuable forthcoming article, Daryl Levinson challenges the widespread supposition that the national government and its officials (and, for that matter, the states and their officials) are inclined to pursue power. Daryl J. Levinson, Empire-Building Government in Constitutional Law, 118 Harv. L. Rev. (forthcoming 2004-2005) (manuscript on file with the Columbia Law Review). His argument is theoretical, rather than empirical, in character, and he does not consider evidence of governmental growthor, for that matter, garner evidence concerning the success of the electorate in checking over-ambitious governments, on which his argument depends. Empirics aside, the argument has other limits that bear brief mention. First, Professor Levinson emphasizes the Framers' perception that the people were the ultimate check on governmental ambition, but systematically underplays (while noting) the extent to which they also thought that institutional checks on the national government were an essential and indispensable part of the Constitution. Id. (manuscript at 3-5). Second, Levinson's argument corrects any notion that governments have unmitigated appetites, but that is a straw man; the threshold question, instead, is whether governments will be inclined to amass and exercise power in a disinterested manner. He appears to concede that they would not, acknowledging that governments will be inclined to expand their jurisdictions. Id. (manuscript at 15). Few would maintain that those governments will exercise that 
It remains unfortunately difficult to assess the harm caused by federalism's underenforcement, let alone the damage attributable to international delegations. But Rubin and Feeley's analysis is also provocative in its view of how federalism may be achieved. It is not invariably the case, as they observe, that increasing federal power decreases state power, as though there were a fixed sum of power with zero-sum tradeoffs. ${ }^{388}$ Even assuming a tradeoff, the addition of federal intervention to areas previously governed only by states "generally means that two governmental hierarchies will be involved in a particular area of governance instead of one," and "[a]ll the advantages associated with power dispersion can flow from this intervention." 389

There are flaws, certainly, with imagining that adding a national alternative "to the previously comprehensive power of the state" 390 gets us the same kind of diffusion that might be achieved through protecting and promoting federalism. ${ }^{391}$ One concerns relative vulnerability: The national government's authority may be constitutionally exclusive and judicially protected-even when it has not acted, courtesy of the dormant Commerce Clause-while the states can rarely say the same. In potentially overlapping areas, moreover, the national government can act preemptively, ${ }^{392}$ or strong-arm the states via conditional preemption or the Spending Clause, while the states have no such recourse. ${ }^{393}$ Adding national authority, for these reasons, detracts from state authority in a way that adding state authority to national authority does not.

Nevertheless, the exercise of imagining top-down diffusion offers several insights potentially relevant to the constitutionality of international

jurisdiction to its fullest extent, and it seems enough that governments reliably accrue authority for its occasional excessive exercise-and, indeed, using that authority seems essential to claiming and preserving jurisdiction.

388. Rubin \& Feeley, supra note 24, at 931-32; cf. Raustiala, Rethinking, supra note 12, at 849-50 (making similar point, premised on analysis of U.S. federalism, in relation to expanding delegations of decisionmaking authority to international institutions).

389. Rubin \& Feeley, supra note 24, at 933-34 (adding that "[t]he second decisionmaker can introduce new standards, subject old ones to debate, increase popular awareness, decrease arbitrary power, restrain corruption and thereby expand liberty-the liberty of individuals from excessive or inappropriate government control”).

390. Id. at 932.

391. I address differences not related to diffusion, such as the difference in the scope of national or international action, in the course of evaluating the impact of international delegations. See infra Part IV.A.3-4.

392. This is the "decided advantage" emphasized in Gregory v. Ashcroft, 501 U.S. 452, 460 (1991) ("As long as it is acting within the powers granted it under the Constitution, Congress may impose its will on the States. Congress may legislate in areas traditionally regulated by the States. This is an extraordinary power in a federalist system.”). Rubin and Feeley acknowledge this, but differ as to how significant it is. Rubin \& Feeley, supra note 24, at 933. With respect to foreign affairs, at least, the combined effect of constitutional and statutory preemption may be quite severe. See supra text accompanying notes 238, 241, 248-249, 373-374.

393. Cf. M'Culloch v. Maryland, 17 U.S. (4 Wheat.) 316, 431 (1819) (observing, famously, that "the power to tax involves the power to destroy"). 
delegations. First, debates about federalism, including its goal of diffusion, are at the core debates about normative values, rather than arid assessments of constitutional text or case law. ${ }^{394}$ Second, in assessing whether federalism promotes those values, it is important-though not necessarily conclusive-to consider whether it is the only means of obtaining them, or the best means. Third, taking federalism's values seriously also requires paying attention to when federalism may betray them. The central example, cited by Rubin and Feeley and others, is that interposing sovereign states above localities may allow the latter to be victimized, reducing any genuine achievement of decentralization. ${ }^{395}$ It remains to consider in Part IV whether the same consequences flow from establishing institutions above the national government.

\section{The Constitutional Case for International Delegations}

To recap: International delegations, an increasingly significant component of America's international relations, look as though they conflict with constitutional principles of nondelegation and federalism-and yet, incongruously, they are permitted to flourish. This incongruity might be judicially remedied, but misgivings about judicial competence make that unlikely and probably unwise. The incongruity might also be based on a misperception-perhaps nondelegation, or federalism, rests on a conceptually untenable premise-but those arguments, too, are not entirely persuasive.

This persistent incongruity is at least partly resolved by the immanent logic of federalism. For the reasons explained below, the most compelling advantage that federalism has over decentralization-the diffusion of authority-actually cuts in favor of international delegations, turning the lack of unilateral U.S. control into a small virtue. After teasing out the

394. Rubin \& Feeley, supra note 24, at 928 (concluding that "the language of the Tenth Amendment is too opaque" to require the dispersion of power among the states; "[r] ecognizing this, no Supreme Court decision has ever rested on its language, and even federalism's most enthusiastic proponents, such as Justice O'Connor, cast their arguments for federalism in functional, or policy terms").

395. See, e.g., id. at 909 (summarizing that "federalism does not diffuse power in our system, but may actually act as an impediment to its diffusion"); id. at 919-20 (noting that "federalism only protects the autonomy of states, not the autonomy or variability of local governments"-and, indeed, prohibits national interference with state direction of local governments-with the result that "federalism does not secure the kind of governmental variability that would provide any realistic choice for citizens; its principal effect in this area is to create a legal barrier against the imposition of such variability as a matter of national policy"). For other leading analyses, see David J. Barron, A Localist Critique of the New Federalism, 51 Duke L.J. 377 (2001) (arguing that increased centralized power does not necessarily impede, and in fact can aid, localized decisionmaking); Richard Briffault, "What About the 'ism'?" Normative and Formal Concerns in Contemporary Federalism, 47 Vand. L. Rev. 1303 (1994) (discussing value of formal, constitutional aspects of federalism, as distinguished from normative discourse about federalism and values); Cross, supra note 24, at 34-51 (citing theoretical and empirical bases for preferring national governance over federalism as a means for advancing localism). 
implications of this claim, including important objections, this Part considers some qualifications.

\section{A. International Delegations and Diffusion}

Commentators sometimes describe international institutions as federal in character because they reserve substantial authority to their national members. ${ }^{396}$ But with respect to any particular nation, particularly those with federal systems, that characterization invites objection. The object of delegating authority to international institutions is, after all, to coordinate policies that formerly were autonomous. By the same token, such institutions tend to make uniform subnational policies that may previously have been diverse in character. The marginal effect of international delegations, in this view, is to harmonize, not decentralize.

At the same time, Part III suggested how international delegations can have compensatory effects that favor federalism's values. If we are concerned about "legislative usurpations" - that " $[\mathrm{t}]$ he legislative department is everywhere extending the sphere of its activity and drawing all power into its impetuous vortex"397_having Congress divest itself of power in favor of international institutions is a sort of self-inoculation. Rubin and Feeley's conceit of federal intervention-with top-down diffusion, engineered by the addition of a national layer rather than the guarantee of a subnational layer-reinforces the point. The premise held in common by Madison, Hamilton, and the modern Supreme Court is that governments should serve to check one another, and that the national government's check on the states was part and parcel of federalism. ${ }^{398}$ If the more governments, the merrier, then the addition of a third, international level may secure many of the same ends as dispersal to the states. Indeed, if we attend to concerns at the Founding that national and state governments might be "mutual rivals and enemies, but . . . uncontrolled by any common superior in their efforts to usurp the authorities of each other," international authority might be regarded as fulfilling by another means the original constitutional vision. ${ }^{399}$

1. International Delegations as a Constraint on U.S. Authority. - An initial question, certainly, is whether international institutions can play a role analogous to that played by the states in domestic affairs. Even as-

396. See, e.g., Charles H. Koch, Jr., Judicial Review and Global Federalism, 54 Admin. L. Rev. 491, 492 (2002) (noting a "move toward 'global federalism," " and cautioning as to its domestic consequences); John O. McGinnis, The Decline of the Western Nation State and the Rise of the Regime of International Federalism, 18 Cardozo L. Rev. 903, 903 (1996) (asserting that "in the West, the regime of nation states has, by degrees, been replaced by . . . 'international federalism'”); see also infra note 523 (citing authorities considering federalism as a design objective).

397. The Federalist No. 48, supra note 340, at 309 (James Madison).

398. See supra note 380 and accompanying text.

399. The Federalist No. 46, supra note 340, at 294 (James Madison). Madison's original "common superior," I hasten to add, was the people. For comment on applying Madison's view to international delegations, see infra text accompanying notes 478-479. 
suming that international law often checks national governments, ${ }^{400}$ the critical inquiry is whether delegated authority may genuinely constrain governments otherwise capable of aggrandizing authority-including the contemporary United States, a "hyperpower" of virtually unrivaled preeminence. ${ }^{401}$ The United States appears to have considerable discretion to chart its own course, and its recent conduct-particularly the more recent invasion of Iraq-is read by some as suggesting little heed for decisions by international institutions. ${ }^{402}$

Even the example of Iraq, in my view, tends to cut in precisely the opposite direction. Assuming, plausibly, that the invasion of Iraq was not legally authorized by the Security Council, ${ }^{403}$ U.S. conduct nonetheless followed the pattern of prior conflicts in respecting the Security Council's Chapter VII authority. ${ }^{404}$ The United States sought and obtained an additional resolution (albeit one of ambiguous import), repeatedly sought Security Council approval for the enforcement of existing resolutions,

400. See supra note 196 (quoting Louis Henkin's famous pronouncement about nearuniversal compliance). See generally Henkin, How Nations Behave, supra note 196, at 42-44, 88-93 (discussing how international law affects national governments).

401. Depictions of the United States as a hegemon are commonplace. While some would welcome that development, see, e.g., The National Security Strategy of the United States of America 1 (Sept. 2002), available at http://www.whitehouse.gov/nsc/nss.pdf (on file with the Columbia Law Review) ("The United States possesses unprecedented-and unequaled-strength and influence in the world."); Niall Ferguson, Colossus: The Price of America's Empire 2 (2004) (describing U.S. empire favorably), others regard it as threatening international institutions—and requiring their reinforcement, see, e.g., Henry J. Richardson, III, U.S. Hegemony, Race, and Oil in Deciding United Nations Security Council Resolution 1441 on Iraq, 17 Temp. Int'l \& Comp. L.J. 27, 81 (2003) ("The emergence of the United States or any other state as global hegemon represents a generic threat to international legal authority, because the corruption of that authority through hegemonic demands is a virtual certainty."); Craig R. Whitney, NATO at 50: With Nations at Odds, Is It a Misalliance?, N.Y. Times, Feb. 15, 1999, at A7 (citing French appraisals of U.S. power and French policy "that multilateral institutions, from the International Monetary Fund to the United Nations, should be strengthened to offset American influence"). For a range of views on the consequences of U.S. power for international law, see United States Hegemony and the Foundations of International Law (Michael Byers \& Georg Nolte eds., 2003).

402. See generally, e.g., Michael J. Glennon, Why the Security Council Failed, Foreign Aff., May/June 2003, at 16 [hereinafter Glennon, Security Council].

403. Whether Security Council Resolution 1441 authorized military intervention or gainsaid it is clearly relevant to this discussion, but I do not purport to resolve that question. Compare, e.g., Sean D. Murphy, Assessing the Legality of Invading Iraq, 92 Geo. L.J. 173, 177 (2004) [hereinafter, Murphy, Assessing] (concluding that the United States lacked Security Council authorization, and that the Security Council's involvement diminished the legality of U.S. actions), with John Yoo, International Law and the War in Iraq, 97 Am. J. Int'l L. 563, 563-71 (2003) (arguing that the Security Council had authorized the use of force).

404. The pattern of prior conflicts also cautions against attributing excessive influence to the Iraq case. See Anne-Marie Slaughter, Misreading the Record, Foreign Aff., July/Aug. 2003, at 202, 203 (contending that "in the first Gulf War, Bosnia, East Timor, Haiti, Rwanda, Somalia, and, after the fact, Kosovo," powerful member states "used the Security Council to frame their common response"). 
conspicuously avoided forcing any adverse vote within the Council, and justified its operation in part as an implementation of extant resolutions. ${ }^{405}$ Obviously, the Security Council did not employ its delegated authority to stop U.S. intervention, but its public failure to embrace the U.S. approach increased the costs of intervention. ${ }^{406}$ Moreover, the U.S. strategy demonstrated that the political and legal legitimacy of Council approval was worth considerable effort and substantial delay, lending credence to its capacity as a legal arbiter; ${ }^{407}$ the Council, for its part, did not capitulate to enormous pressure by the United States, ${ }^{408}$ and its effort created the (unfulfilled) possibility of an eleventh-hour solution. ${ }^{409} \mathrm{Un}$ less the Security Council's resistance leads to its abandonment by those capable of acting unilaterally, ${ }^{410}$ the episode bears out, rather than belies,

405. See George W. Bush, Address to the Nation on Iraq, 39 Weekly Comp. Pres. Doc. 338, 338-39 (Mar. 17, 2003) (emphasizing efforts within the Security Council, and commitment to the UN); Colin L. Powell, A Strategy of Partnerships, Foreign Aff., Jan./ Feb. 2004, at 22, 25 (same); see also Bob Woodward, Bush at War 333 (2002) (quoting remark by Secretary of State Colin Powell to President Bush that "[i]t's nice to say we can do it unilaterally, except you can't"); Bob Woodward, Plan of Attack 224-26, 296-97, 343-45, 357-60, 368-69 (2004) [hereinafter Woodward, Plan of Attack] (describing U.S. efforts to obtain Security Council authorization, notwithstanding resistance within the Bush Administration); Murphy, Assessing, supra note 403, at 237-39 (emphasizing prominence of legal authorization within U.S. political strategy). The preexisting legislative authorization, as it happened, even took the form of an assimilative statute. See Authorization for Use of Military Force Against Iraq Resolution of 2002, Pub. L. No. 107243, § 3(a), 116 Stat. 1498, 1501 (2002) (authorizing President to employ armed forces as necessary and appropriate to defend national security "and enforce all relevant United Nations Security Council resolutions regarding Iraq").

406. See Murphy, Assessing, supra note 403, at 232-33 (concluding that, in part due to its failed attempts to obtain Security Council authorization, "the United States ultimately generated a widespread public perception that the action was illegitimate").

407. Ian Hurd, Responses, Too Legit to Quit, Foreign Aff., July/Aug. 2003, at 204, 205 (noting that Resolution 1441 negotiations demonstrated that "Washington clearly would have preferred to act with council approval rather than without it"); Murphy, Assessing, supra note 403, at 234 (judging that Security Council's recent unwillingness to bend to United States on issue of Iraq may have increased the Council's global reputation and legitimacy).

408. See Alvarez, Hegemonic International Law, supra note 85, at 882 (noting, as counterpoint to examples of U.S. hegemony, that " $[\mathrm{t}]$ hose who suggest that the most effective counterweight to U.S. unilateralism is the Security Council can point to the winter of 2003, when the Council bravely (if ineffectually) refused to acquiesce in the U.S. invasion of Iraq despite forceful, highly public U.S. patron-client pressures"). As one commentator added, Security Council "disapproval was not enough to stop the American operation, but that isn't the point. It raised the costs of unilateralism, and this is the most that the council can do when the great powers clash.” Hurd, supra note 407, at 205.

409. It was conceivable, after all, that the passage of time might have enabled Iraqi compliance with the inspection regime, a conclusive rebuttal of U.S. and British securityrelated assertions, or some other solution. For example, prominent Egyptians forwarded in February 2003 a proposal to grant Saddam Hussein exile, though its ambiguous reception by President Bush effectively rejected it. Woodward, Plan of Attack, supra note 405 , at 314.

410. For concerns along these lines, see Glennon, Security Council, supra note 402, passim; see also Murphy, Assessing, supra note 403, at 235 (observing that adoption of 
the Council's potential for checking national authority-to a degree substantially greater than anything the U.S. states might have accomplished. ${ }^{411}$ The influence of international institutions in post-war Iraq potentially reinforces the lesson. ${ }^{412}$

If war and peace issues are the acid test for international institutions, proof that delegating authority to international institutions checks national governments is much easier to find in other quarters. International trade institutions are a particularly rich source of examples. The TRIPS regime governing protection for patented pharmaceuticals has twice been modified despite resistance by the U.S. national government. ${ }^{413}$ Moreover, WTO dispute settlement mechanisms have on several recent occasions interpreted trade agreements adversely to the United States, and created sufficient financial pressure to force changes in U.S. law. ${ }^{414}$ The most dramatic such defeat concerns U.S. tax law re-

limits to Security Council authorizations of force "might discourage the United States from seeking any Security Council authorization, since the U.S. Executive Branch historically has been unwilling to 'tie its hands' in advance regarding the length of a deployment, either as a matter of international or U.S. law").

411. See supra note 379 (discussing value of federalism in dispersing physical (military) power).

412. See supra text accompanying notes 6-8 (discussing U.S. cession of authority over reconstruction of Iraq to international agencies).

413. See supra text accompanying notes 94-96 (describing controversy over Doha Declaration on the TRIPS). While the U.S. concessions were grudging, the final deal did provide for some U.S.-requested limitations on the ability of developing nations to purchase drugs. Moreover, U.S. agreement seems to have been prompted in part by a desire to achieve progress on other trade talks. See Elizabeth Becker, Poor Nations Can Purchase Cheap Drugs Under Accord, N.Y. Times, Aug. 31, 2003, at A14. The possibility of extrinsic motivations such as these provides a useful caution against deeming any particular negotiating result a victory or a loss for national sovereignty.

414. For example, the United States recently dropped its steel imports safeguards after the WTO Appellate Body upheld an adverse panel decision that threatened to result in the imposition of billions of dollars in punitive tariffs. United States-Definitive Safeguard Measures on Imports of Certain Steel Products (Report of the Appellate Body), WT/DS248/AB/R (Nov. 10, 2003), available at http://docsonline.wto.org/DDFDocu ments/t/WT/DS/259ABR.doc (on file with the Columbia Law Review); see Eliza Patterson, WTO Rules Against US Safeguard Measures on Steel, ASIL Insights, Nov. 2003, Dec. 2003 addendum, available at http://www.asil.org/insights/insigh120.htm (on file with the Columbia Law Review) (concluding that subsequent repeal of steel tariffs "is evidence of the effectiveness of the WTO in enforcing its rules and limiting protectionism"). For background, see generally Kevin K. Ho, Comment, Trading Rights and Wrongs: The 2002 Bush Steel Tariffs, 21 Berkeley J. Int'l L. 825 (2003). The United States claimed, however, that its decision simply reflected the vicissitudes of the U.S. steel industry, rather than any effort to comply with the WTO. See Robert B. Zoellick, U.S. Trade Representative, Remarks at White House Press Briefing (Dec. 4, 2003) (transcript available at http://www. whitehouse.gov/news/releases/2003/12/20031204-11.html) (on file with the Columbia Law Review). Criticisms of the WTO frequently emphasize this function of constraining the national government. See, e.g., Phillip R. Trimble, Globalization, International Institutions, and the Erosion of National Sovereignty and Democracy, 95 Mich. L. Rev. 1944, 1944-45 (1997) (stressing that, while the national government may defy or override WTO obligations as a matter of domestic law, "as a practical matter the WTO's preference 
garding foreign sales corporations (FSCs), in which Congress appears to be bowing before punitive tariffs ${ }^{415}$-notwithstanding portrayals of this dispute as the classic "wrong case," a challenge to an impregnable national measure that risks destruction of the fragile dispute settlement system. ${ }^{416}$ WTO proceedings have also pressured the United States to temper some of its favored unilateral tools, such as interim measures ${ }^{417}$ and extraterritorial sanctions relying on the WTO's "national security exception." 418

In other areas, prophylactic steps taken by the United States suggest the potential for international constraint. The U.S. executive branch has

for international standards and the certainty of sanctions for violations will inevitably induce governmental decisionmakers to prefer compliance with international standards. The resulting practical devolution of decisionmaking authority to international institutions is the essence of the loss of national sovereignty." (footnote omitted)).

415. See United States-Tax Treatment for "Foreign Sales Corporations" (Recourse to Article 21.5 of the DSU by the European Communities) (Report of the Appellate Body), WT/DS108/AB/RW (Jan. 14, 2002), 41 I.L.M. 447, 489 (upholding WTO panel decision that FSCs-used by U.S. companies to shield overseas profit from taxes-provide illegal subsidy and violate trade rules). The U.S. government has dragged its heels in complying. Scott Miller, EU Trade Sanctions Have Dual Edge, Wall St. J., Feb. 26, 2004, at A3. But the gradual imposition of tariffs seems likely eventually to be successful, subject to the vicissitudes of legislative procedure. Edward Alden, House Backs Bill to Avert Trade Sanctions from EU, Fin. Times, June 18, 2004, at 9 (describing passage of FSC-abolishing bills in both the U.S. House of Representatives and the Senate, as well as the President's endorsement of the House bill); see Claire R. Kelly, Realist Theory and Real Constraints, 44 Va. J. Int'l L. 545, 601-02 (2004) (describing FSC controversy as evidencing "how increased delegation raises the likelihood of hard cases" for national sovereigns).

416. Compare Hudec, supra note 56, at 212-13, 218-19 (describing "wrong case" thesis), with A Taxing Challenge for Congress, Fin. Times, Mar. 2, 2004, at 18 (noting potential for a backlash against the WTO, given that the United States "fiercely guards its fiscal sovereignty," but observing that this has not yet transpired).

417. WTO Panel Report, United States-Sections 301-310 of the Trade Act of 1974, II 7.2-7.126, WT/DS152/R (Dec. 19, 1999), available at http://docsonline.wto.org/ DDFDocuments/t/WT/DS/152R.DOC (on file with the Columbia Law Review); see Seung Wha Chang, Taming Unilateralism Under the Multilateral Trading System: Unfinished Job in the WTO Panel Ruling on U.S. Sections 301-310 of the Trade Act of 1974, 31 Law \& Pol'y Int'l Bus. 1151, 1224 (2000) (explaining that while the WTO panel upheld the U.S. position, "the EC achieved a major goal in this panel proceeding by acquiring a U.S. commitment not to exercise the USTR's discretionary power contrary to U.S. obligations" under the WTO).

418. The battle on extraterritoriality was joined over the Helms-Burton Act, 22 U.S.C. $\$ \S 6021-6091$ (2000). Reacting to U.S. threats that it would impose punitive sanctions on foreign firms if they continued to do business in Cuba, America's leading trade partners retaliated by threatening to initiate WTO proceedings-resulting in agreements by those partners to cooperate in discouraging the illegal use of expropriated property, but accompanied by formal waivers by the United States of private sanctions under Title III of Helms-Burton and effective waiver of government-imposed sanctions under Title IV. Michael Mastanduno, Extraterritorial Sanctions: Managing "Hyper-Unilateralism" in U.S. Foreign Policy, in Multilateralism and U.S. Foreign Policy, supra note 4, at 295, 303-11; see Associated Press, U.S. to Levy Cuba Sanctions on Jamaica Firm, Wall St. J., May 25, 2004, at A14 (noting that Title IV has been invoked only rarely, and only against nations that lack strategic importance-and not against those threatening WTO action). 
expressed the view that the enforcement of customary international law via the ATS risks serious complications for its diplomatic relations with foreign countries. ${ }^{419}$ Even the U.S. decision to "unsign" the Rome Treaty, which was widely regarded as evidencing its disregard for international law, reflects an appreciation for the potential constraint of international legal processes - and the permissible means for disengagement. ${ }^{420}$ U.S. efforts to achieve still further distance have also been frustrated by the Security Council's refusal to extend the immunity of U.S. troops from ICC jurisdiction-thus illustrating the constraints imposed even by those institutions in which the United States has disproportionate influence. ${ }^{421}$

There are many more instances in which international institutions have checked exercises of authority by the U.S. national government, and the fervent objections to the power implied by international delegations suggest that their critics agree. ${ }^{422}$ One puzzle is why the United States might accept this state of affairs, as opposed to one in which it exhibits greater dominance. ${ }^{423}$ The structure of some organizations has been historically determined, and may resist change, ${ }^{424}$ but it is also possible to

419. Brief for the United States as Respondent Supporting Petitioner at 40-46, Sosa v. Alvarez-Machain, 159 L. Ed. 2d 718 (2004) (No. 03-339) (citing example of South Africa).

420. See Swaine, Unsigning, supra note 119, at 2061-63 (contrasting formal propriety of U.S. unsigning with international criticisms thereof). Statements of U.S. officials highlighted the perceived risks that ICC prosecutions and treaty amendments posed for U.S. interests. See, e.g., Marc Grossman, American Foreign Policy and the International Criminal Court, Remarks to the Center for Strategic and International Studies (May 6, 2002), available at http://www.state.gov/p/9949.htm (on file with the Columbia Law Review).

421. The U.S. failure to secure an extension followed a plea from the SecretaryGeneral to maintain the "primacy of law" and "common purpose." Warren Hoge, U.S. Drops Plan to Exempt G.I.'s from U.N. Court, N.Y. Times, June 24, 2004, at A1. It may remain possible, however, for the United States to obtain immunity through missionspecific extensions of immunity, as in the resolution establishing a multinational force in Liberia. S.C. Res. 1497, U.N. SCOR, 58th Sess., 4803d mtg., at 2, U.N. Doc. S/RES/1497 (2003).

422. See, e.g., supra text accompanying notes 12, 14-15.

423. For these purposes, I assume the most difficult case-that is, one in which (a) the United States might act independently, and (b) merely symmetrical benefits of international delegations (e.g., the prospect that the United States may prevail in equal measure against other WTO members) are insufficient, because hegemons may strike less balanced bargains. Sometimes, it should also be noted, delegations may simply be mistakes. See, e.g., Adam Liptak, Review of U.S. Rulings by Nafta Tribunals Stirs Worries, N.Y. Times, Apr. 18, 2004, at A20 (quoting Abner Mikva, a former judge and congressman and sometime NAFTA arbitrator, as representing that "[i]f Congress had known that there was anything like this in NAFTA . . . they would never have voted for it"); id. at 20 (quoting representation by Senator John Kerry that "not a single word was uttered" on Chapter 11 in congressional debates over NAFTA).

424. The most obvious example is the UN Security Council, on which none of the original Permanent Members have lost their seats, despite changes in stature relative to the other members. Other institutions, like those controlling the establishment of customary international law, may also be slow to bend their ground rules to a hegemon's influenceeven if they yield to a hegemon in particular instances. See, e.g., Edward T. Swaine, Rational Custom, 52 Duke L.J. 559, 608-12 (2002) (discussing advent of continental shelf 
theorize how a hegemon's contemporaneous interests may be served by consigning itself (with others) to the constraints imposed by international institutions. One hypothesis is that a leading nation may agree to restrain the indiscriminacy and severity of its actions and sacrifice some of the returns it might gain through the unconstrained use of its authority in order to spare resources it would otherwise spend coercing lesser nations and to obtain insurance against its future decline. ${ }^{425}$ Vesting institutions with delegated authority may be part of the leader's concession, part of an attempt to insinuate (constrained) dominance into the institutional scheme, or part of a mutual attempt to permit institutional adaptation and ensure greater lock-in for both the leading and lesser nations. ${ }^{426}$ These and comparable theories offer plausible accounts for the more unlikely delegations (like those to the UN and the WTO) that appear to have most compromised U.S. sovereignty. ${ }^{427}$

The question remains whether an international level of governance, considered for its own sake, ultimately suffers from the same limitations as adding (and growing) the national level of governance did in the United States. ${ }^{428}$ As part of the balancing of underenforced values, it is then necessary to consider whether there are other federalism-related costs to international delegations, and whether emphasizing the federalist virtues of international delegations ignores the delegation side of the ledger.

regime through the Truman Proclamation of 1945). But cf. Goldsmith \& Posner, A Theory of Customary International Law, supra note 130, at 1123-24 (arguing that coercively determined norms cannot genuinely be described as customary international law); id. at 1149, 1160, 1162, 1167 (citing examples of coerced behavior).

425. See G. John Ikenberry, Multilateralism and U.S. Grand Strategy, in Multilateralism and U.S. Foreign Policy, supra note 4, at 121, 127-36 [hereinafter Ikenberry, Multilaterialism]; id. at 127 et seq. (finding evidence supporting this hypothesis in U.S. postwar practices); see also G. John Ikenberry, After Victory: Institutions, Strategic Restraint, and the Rebuilding of Order After Major Wars 4-6 (2001) (finding evidence of similar, self-imposed restraints for other powers following major wars in the modern era).

426. Professor Ikenberry's model does not lend itself to the diagnosis of these interests, but he does note the leading state's interest in trying to lock in other states "while trying to minimize limitations on its own policy autonomy and discretionary power," even as it must make commitments to purchase the cooperation of other states. Ikenberry, Multilateralism, supra note 425 , at 125 .

427. Other hypotheses have been offered to explain how international institutions may enhance, rather than retard, sovereignty_raising the question whether international delegations do a better job of enhancing than constraining the tendency of the federal government to aggrandize power. See, e.g., Raustiala, Rethinking, supra note 12, at 857-62 (describing how interdependence has changed meaning of sovereignty and how participation in institutions is required to realize this new sovereignty); id. at 863-69 (describing how international institutions might ward off private rent seekers and enhance bureaucratic power).

428. I address another significant concern, the lack of democratic control over international institutions, in connection with delegation-related objections. See infra notes 474-482 and accompanying text. 
2. International Delegations and Relative Gains to Diffusion. - If adding a national layer to state governance works less well at diffusing power than would securing constitutional federalism, international delegations fall somewhere in the middle. The legal force of international delegations, as previously discussed, is typically less severe than ordinary federal legislation; treaties and congressional-executive agreements are often deemed non-self-executing, ${ }^{429}$ and the rules and decisions issued by international institutions are for the most part treated likewise. Customary international law, at least, is widely regarded as binding federal law, but its preemptive application-and the limits thereto-are almost entirely hypothetical. 430

What, if anything, ensures that this will continue to be the case? What prevents the national government from conferring preemptive authority on international organizations, or enacting a statute that clarifies and extends the effect of customary international law? Those wary of depending upon the political safeguards of federalism may be equally wary of the national government's largesse with respect to international delegations. ${ }^{431}$ In domestic negotiations concerning the implementation of the Uruguay Round and NAFTA, for example, states were concerned that no matter how accommodating federal legislation might prove, it was still preemptive in character, and prone to aggressive interpretation by subsequent administrations. ${ }^{432}$ Nor have states relaxed entirely in the years since. ${ }^{433}$

429. See Henkin, Foreign Affairs, supra note 15, at 198-204 (describing and criticizing this practice); see also id. at 180-84 (describing and criticizing practice of entering reservations to ensure non-self-execution); supra text accompanying note 250 (noting dispute regarding presumption for or against self-execution).

430. See Curtis A. Bradley, The Juvenile Death Penalty and International Law, 52 Duke L.J. 485, 552-53 \& n.315 (2002) (citing, as an exceptional case potentially involving preemption of state law, Republic of Argentina v. City of New York, 250 N.E.2d 698, 704 (N.Y. 1969)); Curtis A. Bradley, World War II Compensation and Foreign Relations Federalism, 20 Berkeley J. Int'l L. 282, 293-94 (2002) (asserting that "despite claims by many scholars that customary international law has the status of preemptive federal law, there are essentially no decisions in U.S. history actually using customary international law to preempt state law"); Ernest A. Young, Sorting Out the Debate Over Customary International Law, 42 Va. J. Int'l L. 365, 497 (2002) (reporting that “[t]o my knowledge, the preemptive force of customary international law has never been applied to supplant an otherwise valid state law rule. Nor is it likely to be in the future" (footnote omitted)).

431. See supra notes 326, 360 and accompanying text (noting literature concerning political safeguards of federalism).

432. See Sager, One Voice, supra note 362, at 110-11.

433. See, e.g., Nat'l Ass'n of Att'ys Gen., Resolution: In Support of State Sovereignty and Regulatory Authority (adopted Mar. 19-22, 2002), at http://www.naag.org/naag/ resolutions/res-spr02-regauth.php (on file with the Columbia Law Review) (arguing that NAFTA Chapter 11 could undermine authority of state and local governments and could privilege foreign investors at the expense of U.S. citizens); Letter from National Conference of State Legislatures, Council of State Governments, the United Conference of Mayors, and the National League of Cities, to Ambassador Robert Zoellick, U.S. Trade Representative (Sept. 23, 2003), available at http://www.ncsl.org/standcomm/scecon/ Trade_Principalsltr92303.htm (on file with the Columbia Law Review) (calling for, inter 
The treatment the states were afforded in those episodes, in which they wound up enjoying dispensations above and beyond those enjoyed by the national government, ${ }^{434}$ can hardly be guaranteed. But at the same time, there are deep-seated differences between the preemptive biases of domestic legislation and the acts conferring authority on international institutions. Most important, the obligations that may be developed under international authority presumptively apply against the national government as well, which may make it hesitate before giving them automatic legal effect. Even where the international institution's scope of authority is more likely to implicate state sovereignty under the U.S. system, the national government's long-term interests apparently include maintaining the flexibility afforded by a dualist system.

This symmetry of interests is not, of course, unalterable. International law's bias toward making the national government alone responsible for international delicts might, in theory, be offset were the national government to legislate so as to give international rules and decisions preemptive effect as against state law only-diminishing any prior symmetry of interests. ${ }^{435}$ But the weight of practice is surely to the contrary. The U.S. persistence in seeking federalism-based RUDs above and beyond those required by the Constitution, ${ }^{436}$ and its protracted defense of state interests arising from violation of the Vienna Convention on Consular Relations, ${ }^{437}$ indulged the states even where national and state interests

alia, improved consultation with national authorities, adoption of presumption against preemption, and respect for state and local law).

434. See Sager, One Voice, supra note 362, at 106-07; see also supra note 330 and accompanying text (noting relevant provisions of NAFTA and the Uruguay Round).

435. It seems unlikely that the discrimination would be accommodated on the international plane, given the resistance of other nations and international institutions to assuming claims against the states. For discussion, see Swaine, Treaty Power, supra note 224 , at $450-57$.

436. See id. at 441-47.

437. The Convention grants foreign detainees the right to consult with consular officials. Vienna Convention on Consular Relations and Optional Protocol on Disputes, Apr. 24, 1963, art. 36, II 1(b), 21 U.S.T. 77, 101, 596 U.N.T.S. 261, 292. Several cases before the International Court of Justice have concerned violations by U.S. states of their obligation under the Convention. See Concerning Avena and Other Mexican Nationals (Mex. v. U.S.), Judgment, II 42-46 (March 31, 2004), available at http://www.icj-cij.org/ idocket/imus/imusframe.htm (on file with the Columbia Law Review); LaGrand Case (F.R.G. v. U.S.), 2001 I.C.J. 466, 516 (June 27); LaGrand Case (F.R.G. v. U.S.), Order, Request for the Indication of Provisional Measures, 1999 I.C.J. 9, 10 (Mar. 3); Concerning the Vienna Convention on Consular Relations (Para. v. U.S.), Order, Request for the Indication of Provisional Measures, 1998 I.C.J. 248, 253-55 (Apr. 9). In those proceedings, the United States invoked federalism as a reason to limit any remedy for the states' breach. See, e.g., Counter-Memorial Submitted by the United States of America (LaGrand Case (F.R.G. v. U.S.)) II 121-126 (Mar. 27), available at http://www.icj-cij.org/icjwww/ idocket/igus/igusframe.htm (on file with the Columbia Law Review) (alluding to constitutional restrictions on U.S. federal authority); Counter-Memorial Submitted by the United States of America (Concerning Avena and Other Mexican Nationals (Mex. v. U.S.)) 185, 193, 214-15 (Nov. 3, 2003), available at http://icjwww/idocket/imus/imusframe.htm (on file with the Columbia Law Review). The Supreme Court, and other federal courts, have 
nominally diverged. While the states' traditional roles may protect them more effectively in domestic matters ${ }^{438}$ the visceral U.S. distrust of international institutions-exemplified still more clearly in non-self-execution RUDs, which benefit the national government and the state alike ${ }^{439}$-at least arguably diminishes the gap. ${ }^{440}$

Of more immediate relevance to international delegations, the legislation implementing NAFTA and the Uruguay Round suggests that the pull of symmetry - in which the national government protects the states as it would itself-is strong. Each statute contains a section barring any treaty provision "inconsistent with any law of the United States" from having legal effect. ${ }^{441}$ The symmetrical reservation of U.S. sovereignty is cou-

also resisted U.S. obligations, which have thus far arisen solely with respect to state prosecutions. See F.R.G. v. United States, 526 U.S. 111, 112 (1999) (per curiam) (asserting, in declining original jurisdiction, that "a foreign government's ability here to assert a claim against a State is without evident support in the Vienna Convention and in probable contravention of Eleventh Amendment principles"); Breard v. Greene, 523 U.S. 371, 377 (1998) (per curiam) (suggesting that the Eleventh Amendment might bar suit by Paraguay to set aside criminal conviction and sentence); Medellin v. Dretke, 371 F.3d 270, 280 (5th Cir. 2004) (holding that precedent dictated that petitioner's claim was procedurally defaulted and, in the alternative, that Vienna Convention did not confer an individually enforceable right); Swaine, Treaty Power, supra note 224, at 435 n.131 (citing additional case law).

The effect of insulating state criminal processes from federal intervention, however, may have the indirect effect of necessitating intervention by state authorities-since, given the lack of any available relief through federal habeas corpus proceedings, state postconviction processes may be the only recourse. See Torres v. Oklahoma, No. PCD-04442, slip op. at 7 (Okla. Crim. App. May 13, 2004) (Chapel, J., specially concurring) (noting that "Avena directs the United States to review and reconsider Torres' conviction and sentence in light of the consequences of the treaty violation"). But see id., slip op. at 3 (Lumpkin, J., dissenting) (concluding that Torres's claim was barred by res judicata and waiver, and that "[t]he Avena decision cannot revive a stale claim").

438. See supra text accompanying note 373 (discussing Am. Ins. Ass'n v. Garamendi, 539 U.S. 396 (2003)).

439. See Bradley \& Goldsmith, Treaties, supra note 65, at 407-09, 419-22, 447-49 (describing, and defending, practice). The national government may take the additional step, in the further legislation occasioned by some non-self-execution RUDs, of simultaneously precluding inferences of preemptive or later-in-time effect. See infra text accompanying note 441 (noting provisions in Uruguay Round Agreements Act and NAFTA).

440. U.S. attitudes toward international institutions vary across time and by institution; they also may not be markedly more hostile to the principle of international institutions than those of citizens in other developed states. See Luck, supra note 4, at 34-40. But it is fair to assume that Americans are more likely to be vigilant in insisting on safeguards as against international institutions, including for state and local governments, than they are with respect to incursions by the national government. See, e.g., Rubenfeld, supra note 14, at 27-29 (depicting inconsistency between constitutionalism as understood by Americans and its international variants, which embody "universal principles that derive their authority from sources outside natural democratic processes"); Peter J. Spiro, The New Sovereigntists, Foreign Aff., Nov./Dec. 2000, at 9, 9 (describing keen antiinternationalist tendencies in American thought).

441. NAFTA Implementation Act, 19 U.S.C. \$ 3312(a)(1) (2000); Uruguay Round Agreements Act, 19 U.S.C. $\$ 3512(\mathrm{a})(1)$. While the reference to U.S. law may be 
pled with a bar on private enforcement against either the United States or the states. ${ }^{442}$ The statutes do acknowledge the ability of the United States to challenge state law for its inconsistency with the agreement (and not vice versa), and presume the ability of the United States to legislate so as to preempt inconsistent state law (again, not vice versa). But the accompanying Statement of Administrative Action notes that such steps were never taken under the GATT ${ }^{43}$ — and each piece of implementing legislation is accompanied by safeguards designed to accommodate the states at the international and at the national levels. ${ }^{444}$

Anecdotal evidence aside, the problem remains that international delegations are not themselves constitutionally guaranteed. If the managerial decentralization advocated by Rubin and Feeley is vulnerable to the criticism that it lasts only so long as it suits the national government, don't international delegations persist for only so long as the United States desires them? Whatever the frailties of the Tenth Amendment, one may at least depend upon the continuing existence of the states, ${ }^{445}$ whereas U.S. international commitments are hardly so certain. The lastin-time rule, indeed, suggests a bias against attributing any constitutional character to international commitments. ${ }^{446}$

ambiguous, the legislative history of the Uruguay Round Agreements Act makes clear that the language was intended to encompass both federal and state law, and reflected concern about the lawmaking potential of the WTO in particular. The Uruguay Round Agreements Act: Statement of Administrative Action, attached to H.R. Rep. No. 103-826, pt. 1, at 656 (1994), reprinted in 1994 U.S.C.C.A.N. 4040, 4050.

442. See NAFTA Implementation Act \$3312(c); Uruguay Round Agreements Act $\S 3512(\mathrm{c})$.

443. H.R. Rep. No. 103-361, pt. 1, at 142 (1993), reprinted in 1993 U.S.C.C.A.N. 2863, 2872 (quoting representation by Michael Kantor, U.S. Trade Representative, that "[a]lthough ultimately the federal government . . . retains the authority to overrule inconsistent state law through legislation or civil suit, use of this authority has not been necessary in the nearly half-century history of the GATT or the five years that the CFTA has been in effect"); accord Statement of Administrative Action, H.R. 5110, 103d Cong. (1994); The Uruguay Round Agreements Act: Statement of Administrative Action, attached to H.R. No. 103-826, pt. 1, at 656 (1994), reprinted in 1994 U.S.C.C.A.N. 4040, 4053 (stating that federal government retains authority to overrule inconsistent state law, but noting that this authority had never been necessary during history of GATT).

444. These include consultation prior to and during the implementation of the agreement, involvement in the development of U.S. positions in the dispute resolution process, etc. See supra notes 16, 330 and accompanying text.

445. See U.S. Const. art. IV, $\S 3$, cl. 1 (protecting states from loss of territory absent their consent); id. art. IV, $\S 4$ (guaranteeing to each state a republican form of government).

446. See Breard v. Greene, 523 U.S. 371, 376 (1998) (per curiam) (“‘[A]n Act of Congress . . . is on full parity with a treaty, and ... when a statute which is subsequent in time is inconsistent with a treaty, the statute to the extent of conflict renders the treaty null.'” (quoting Reid v. Covert, 354 U.S. 1, 18 (1957) (Black, J.))); The Chinese Exclusion Case, 130 U.S. 581, 600 (1889) ("[T] he last expression of the sovereign will must control.”); Whitney v. Robertson, 124 U.S. 190, 194 (1888) (“[I]f there be any conflict between the stipulations of the treaty and the requirements of the law, the latter must control."); Restatement of the Law (Third) of the Foreign Relations Law of the United 
The last-in-time rule does not, however, affect a nation's obligations on the international plane,${ }^{447}$ where obligations are surprisingly stickyif not precisely constitutional in tenure. As previously discussed, the nature of international institutions exercising delegated authority-the difficulty in constraining their behavior, the difficulty in escaping their jurisdiction, and the continued (relative) benefits of membership-makes exit difficult. ${ }^{448}$ As compared to the domestic context, Congress not only cedes authority, but also finds it relatively hard to reassume, and thereby assumes durable obligations binding the national government. This characteristic, which distinguishes international delegations from the baseline of ordinary legislation, may also redeem them as a constitutional safeguard.

3. International Delegations and the Other Virtues of Federalism. - Diffusion is not the only plausible justification for domestic federalism. Another justification involves citizen choice: the prospect that federal systems better accommodate a heterogeneous society by permitting citizens to locate and influence polities more closely aligned with their preferences. ${ }^{449}$ The claimed benefits of citizen choice dovetail with the idea that federalism may help promote affective or political communities, which may then in turn help constitute individual identity. ${ }^{450}$

Neither value would be satisfied by diffusion on a top-down, national basis. It is not as though exclusive federal authority simply substitutes for state authority; 451 if the legislation is nationwide in its application, it displaces state authority, in all its variety, all at once. ${ }^{452}$ The number of laws bearing on a particular resident, at a given point in time, may not vary as between the scenarios, ${ }^{453}$ but the number of different laws that they

States § 115(1) (a) (1987) (providing for superseding effect of later statutes); id. § 115(2) (providing for superseding effect of later treaties); supra notes 184-188 (citing authorities suggesting that vulnerability to last-in-time doctrine diminishes significance of internationally delegated authority).

447. Restatement (Third) of Foreign Relations Law of the United States § 115(1) (b) ("That a rule of international law or a provision of an international agreement is superseded as domestic law does not relieve the United States of its international obligation or of the consequences of a violation of that obligation.").

448. See supra text accompanying notes 184-185, 285-297.

449. See, e.g., Rubin \& Feeley, supra note 24, at 918-20 (critically reviewing claim).

450. Id. at 936-51 (critically reviewing claim). I address the related concerns about the democratic costs of international delegations further below. See infra text accompanying notes 474-482.

451. Rubin \& Feeley, supra note 24, at 934 (describing how, where the federal government has taken complete control of an area, "federal intervention neither increased nor decreased the dispersion of power").

452. The equity concerns motivating national uniformity may be persuasive or not, but there is little doubt that they motivate national intervention. See McKinnon \& Nechyba, supra note 383 , at $6,9-10,54-55$ (arguing that "an equality of outcomes standard of equity in the provision of a particular service," such as public education, "leads to centralization of that service").

453. That is, between the scenario in which the states are constitutionally guaranteed a role in order to diffuse power held by the national government, and the scenario in 
might potentially access and influence does. Rubin and Feeley reply, of course, that the national government can accommodate differences through decentralization. They also suggest that citizen choice and community building take place, typically, at a level well below the state, that both are driven more by political culture than by legal forces, and that in the United States each increasingly pales in comparison to the development of a national, more homogenous culture. ${ }^{454}$

Whatever the merits of this rebuttal for domestic, top-down diffusion, it is inadequate for the problems posed by international delegations. Federalism vindicated through international delegations appears inconsistent with both national and subnational mechanisms for securing citizen choice and community building. If citizen affinity resides, in any case, no higher than the national level, the transnational homogeneity created by international institutions is unsatisfactory. ${ }^{455}$

At least two offsetting considerations warrant mention. First, international institutions may help correct imperfections in U.S. federalism. Constitutional federalism preserves state sovereignty not only to protect the states and their institutions against national intervention, but also to preserve competition among states and to prevent undesired interference by some states with others. ${ }^{456}$ State barriers to trade with disproportionate impact on other states, for example, warrant congressional intervention, or constitutional preclusion, in a fashion perfectly consistent with respect for federalism. The exaggerated political clout of small states within the national government, moreover, may block acts that might be taken on behalf of other states. ${ }^{457}$ International intervention against such state barriers, or against national barriers affecting local interests, thus may be of value in curing political impediments to national action. ${ }^{458}$

which the national government gradually intervenes in areas previously regulated exclusively by the states.

454. See Rubin \& Feeley, supra note 24, at 940-50.

455. It is possible, presumably, for international institutions to decentralize, and there is occasional recognition within organizations of principles like subsidiarity or devolution. See, e.g., OECD, Managing Across Levels of Government 13 (1997), available at http:// www.oecd.org/dataoecd/10/14/1902308.pdf (on file with the Columbia Law Review) (examining concept of governance relative to public management changes and reforms in intergovernmental relations in OECD member states). Perhaps the most tangible realization has been special and differential accommodation for developing countries. Joint Group on Trade and Competition, OECD, The Role of "Special and Differential Treatment" at the Trade, Competition and Development Interface 20-21 (Dec. 4, 2001), OECD Doc. COM/TC/DAFFE/CLP(2001)21/Final, available at http://www.oecd.org/ dataoecd/49137/2072318.pdf (on file with the Columbia Law Review).

456. See, e.g., Shapiro, supra note 325, at 76-77; see also Bednar et al., supra note 383 , at $224-25,228-29$.

457. See supra note 316 .

458. The steel safeguards found illegal by the WTO, for example, benefited some U.S. companies (steel producers) at the expense of others (those consuming steel), giving rise to conflicting regional interests even within the United States. The original decision to impose tariffs seems to have been predicated on the importance of securing political 
International institutions occasionally address constitutional interstices as well. For example, as previously noted, the review by GATT panels of state alcohol taxes and regulations struck at the heart of state authority under the Twenty-first Amendment. ${ }^{459}$ Whether or not that state authority constitutes an exception to the dormant Commerce Clause remains unclear, but some precedent suggests that states have retained exceptional authority to significantly impair interstate trade. ${ }^{460}$ In such an event, international intervention-heedless, in effect, of an ad hoc state prerogative-may be the only mechanism for securing a prerogative for the greater good.

Second, international delegations present the question of whether there can be new kinds of communities, beyond both localities and nation-states. At present, there is no global political community as such, and no means of guaranteeing the liberal preconditions for a polity; ${ }^{461}$ any stronger, but nonpolitical, bond appears untenable simply as a matter of scale. ${ }^{462}$ While there are those who insist on the potential for collec-

support in steelmaking states like Ohio, Pennsylvania, and West Virginia; over time, political advisors came to weigh more heavily the interests representing steel users, and to consider the prospect that retaliatory tariffs imposed by the European Union could fall on equally significant states. See Paul Blustein \& Jonathan Weisman, U.S. Loses Appeal on Steel Tariffs, Wash. Post, Nov. 11, 2003, at A1. A subsequent panel decision finding that U.S. cotton subsidies were unlawful may prove to have a similarly sharp regional impact, Paul Blustein, U.S. Farmers Get a Lesson In Global Trade, Wash. Post, Apr. 28, 2004, at A1, and prove a blow to politically dominant lobbies within the United States-to the benefit of other interests that may prefer free trade. See The Cotton Club, Wall St. J., Apr. 28, 2004, at A16; Scott Miller, WTO Cotton Ruling May Help Subsidy Opponents, Wall St. J., Apr. 28, 2004, at A15. While these benefits may seem like happenstance, the antidiscrimination function performed by international trade institutions serves as an excellent examplar. See, e.g., McGinnis \& Movsesian, World Trade Constitution, supra note 284, at 542-48 (describing democracy-reinforcing effects of WTO).

459. See supra note 333 and accompanying text.

460. The Supreme Court has recently granted certiorari on several of the cases raising this issue. Compare Heald v. Engler, 342 F.3d 517, 524-28 (6th Cir. 2003) (holding that state law permitting direct shipment sales by in-state wineries, but restricting imports from out-of-state wineries, violated the dormant Commerce Clause), cert. granted in part sub nom. Granholm v. Heald, 158 L. Ed. 2d 962 (2004), cert. granted in part sub nom. Mich. Beer \& Wine Wholesalers Ass'n v. Heald, 158 L. Ed. 2d 962 (2004), Dickerson v. Bailey, 336 F.3d 388, 395-96 (5th Cir. 2003) (same), and Beskind v. Easley, 325 F.3d 506, 514-17 (4th Cir. 2003) (same), with Swedenburg v. Kelly, 358 F.3d 223, 231-39 (2nd Cir. 2004) (upholding similar state law against dormant Commerce Clause challenge), cert. granted, 158 L. Ed. 2d 962 (2004), and Bridenbaugh v. Freeman-Wilson, 227 F.3d 848, 853-54 (7th Cir. 2000) (same), cert. denied, 532 U.S. 1002 (2001). See generally Craig v. Boren, 429 U.S. 190, 206 (1976) (describing precedent as confirming that Twenty-first Amendment "primarily created an exception to the normal operation of the Commerce Clause").

461. See supra text accompanying note 303 .

462. Rubin and Feeley, distinguishing between political and affective communities, describe the latter as involving a personal, emotional connection among people, "often [established] through ongoing, day-to-day relationships.” Rubin \& Feeley, supra note 24, at 938-39. The notion of affective communities is sometimes sketched more broadly, see, e.g., Robert Paul Wolff, The Poverty of Liberalism 187-92 (1968) (defining an affective community as "the reciprocal consciousness of a shared culture"), but as Rubin and Feeley 
tive global decisionmaking, ${ }^{463}$ or the possibility that some other kind of collectivity may arise, ${ }^{464}$ these arguments seem too utopian to be considered in any contemporary analysis.

At the same time, establishing a constitutional rule limiting U.S. engagements would be unduly severe. Democratic community building has gradually moved from small city-states to nations, and the notion of global communities is not self-evidently more outlandish than the modern nation-state may have once seemed. ${ }^{465}$ If U.S. ambivalence about international institutions were ossified as a constitutional bar, it would risk estranging U.S. citizens from the rest of the world, limiting both the nature of their own community and the possibility that a shared community might arise. Any constitutional barrier to international delegations would also interfere with the potential competition for affinity among the international community, the federal government, and the states. ${ }^{466} \mathrm{Fi}^{-}$ nally, a constitutional bar would reduce the prospect for heterogeneity in the linkages between local communities and international institutions; at present, the dialogic relationship emerging from U.S. relationships with international institutions may help establish a new model for imitation by other nations struggling to effectively integrate themselves. ${ }^{467}$ Enforcing a broad proscription on international engagements, accordingly, would be substantially inconsistent with the broader thesis of federalism.

observe, usually in the context of personal relationships, Rubin \& Feeley, supra note 24, at 937 n.124. Given those preconditions, they naturally conclude that "all, or virtually all, American states are far too large to function as affective communities"-presumably casting doubt on the feasibility of global affective communities. Id. at 940 .

463. See, e.g., Richard Falk \& Andrew Strauss, On the Creation of a Global Peoples Assembly: Legitimacy and the Power of Popular Sovereignty, 36 Stan. J. Int'l L. 191 (2000) (proposing grassroots organization of popularly elected international citizens' assembly).

464. See, e.g., Akira Iriye, Global Community: The Role of International Organizations in the Making of the Contemporary World 192-93 (2002) (discussing prospect that international institutions will contribute to heterogenous world community); Pippa Norris, Global Governance and Cosmopolitan Citizens, in Governance in a Globalizing World 155, 173-75 (Joseph S. Nye, Jr. \& John D. Donahue eds., 2000) (citing evidence indicating resistance to cosmopolitanism, but also long-term movement of public opinion "in a more internationalist direction"). See generally Symposium, What is the International Community?, Foreign Pol'y, Sept./Oct. 2002, at 28 (presenting nine authors' views on existence, membership, and purposes of international community).

465. See Roland Axtmann, Liberal Democracy into the Twenty-First Century 117-18 (1996).

466. Cf. Todd E. Pettys, Competing for the People's Affection: Federalism's Forgotten Marketplace, 56 Vand. L. Rev. 329, 338-44 (2003) (describing constitutional framework for such competition between national government and states).

467. Cf. Catherine Powell, Dialogic Federalism: Constitutional Possibilities for Incorporation of Human Rights Law in the United States, 150 U. Pa. L. Rev. 245 (2001) (discussing constitutional implications of adoption of international treaties and norms by U.S. state and local governments). The potential for an international dialogue is abundantly clear. See John H. Jackson \& Alan O. Sykes, Questions and Comparisons, in Implementing the Uruguay Round 457, 457-59 (John H. Jackson \& Alan O. Sykes eds., 1997). 
4. The Tension Between Federalism and Nondelegation. - A final, critical consideration is whether this redemption of international delegations in federalism terms has simply forgotten about the nondelegation problem. Nondelegation doctrine has as its object, after all, preventing Congress from giving away power. If we take federalism to be concerned with the prospect that Congress will seize power, and if we applaud its choice to do the opposite by giving away power to international institutions, then perhaps we are simply denying that delegation is of primary concern. ${ }^{468}$

One answer is that it is simplistic to speak of losses of congressional power in this sense. Part of Posner and Vermeule's claim, recall, was that delegating is not necessarily inconsistent with congressional control over its agents (or with the ability of voters and interest groups, in turn, to exercise control over Congress). ${ }^{469}$ Even if that claim has less force with regard to international delegations, for reasons already belabored ${ }^{470}$ the fact remains that the impetus for delegation derives from need and expediency - as with any delegation, we may suppose, Congress delegates because it cannot manage all tasks by itself, or because its members wish to take advantage of an agent's talents. ${ }^{471}$ Even where Congress delegates in order to off-load perceived responsibility, it presumably has a reason, even if it is still feasible to hold it accountable for its choices. ${ }^{472}$

Delegations, in this view, are primarily about the changed use of congressional power, with fewer negative implications for the underlying values of nondelegation than might be supposed. With regard to welfare effects, it is hard to say whether international delegations are generally detrimental, and impossible to show that they are invariably so. International delegations may be positive not only due to overall capacity restraints on Congress, or because of the diminished sway of interest groups, but also because of the gains from international cooperation that could not be achieved unilaterally. ${ }^{473}$

The antidemocratic effects, however, are more troubling. International delegations give power to officials and institutions that "are not accountable, directly or indirectly, exclusively to the American electo-

468. See The Federalist No. 48, supra note 340, at 309 (James Madison) (acknowledging“danger from legislative usurpations”); Freedman, supra note 298, at 309 (noting that "the Framers may not have regarded the prospect of voluntary legislative divestments of power as particularly worrisome"); Posner \& Vermeule, Interring, supra note 23, at 1733-34 ("The Framers' principal concern was with legislative aggrandizement-the legislative seizure of powers belonging to other institutions-rather than with legislative grants of statutory authority to executive agents.").

469. See supra notes 267-272, 299-300 and accompanying text.

470. See supra notes 273-296, 303-314 and accompanying text.

471. See Posner \& Vermeule, Interring, supra note 23, at 1744.

472. See id. at $1746-47$.

473. See supra text accompanying note 297. 
rate," ${ }^{474}$ and indeed may not be accountable to much of anyone at all. ${ }^{475}$ The comparison as against any harm to governance by American states is even starker: International institutions have less proximity to the people than does the national government, let alone state or local governments. ${ }^{476}$

The implications of this comparison for the case against international delegations may be profound. International institutions serve the end of diffusion because they establish another level of governmentwith its own entitlement to make law-to check the objectives of the national and state governments. But the Framers' case for the checking function performed by national and state governments on one another depended on their common fidelity to the American people. As Madison observed in The Federalist No. 46,

[T] he ultimate authority, wherever the derivative may be found, resides in the people alone, and ... it will not depend merely on the comparative ambition or address of the different governments whether either, or which of them, will be able to enlarge its sphere of jurisdiction at the expense of the other. Truth, no less than decency, requires that the event in every case should be supposed to depend on the sentiments and sanction of their common constituents. ${ }^{477}$

Madison implied that even if a government less tied to a common constituency might check the ambitions of other governments, it should not be embraced for extrinsic, democratic reasons. ${ }^{478}$ If so, the check

474. Golove, supra note 15, at 1699-1700 (describing objection posed by some scholars); see also supra text accompanying note 312. Professor Golove is dubious, however, that this rises to a constitutional offense. Golove, supra note 15, at 1699-1701; accord John Gerard Ruggie, American Exceptionalism, Exemptionalism and Global Governance 26 (Kennedy School of Government Working Paper, RWP04-006, Feb. 2004) (on file with the Columbia Law Review).

475. See supra notes 303-309 and accompanying text.

476. This ignores, for simplicity's sake, arguably antidemocratic characteristics of federalism, as in the power of small states in national assemblies. See supra note 316. But see Robert A. Dahl, Federalism and the Democratic Process, in Nomos XXV: Liberal Democracy 95, 107 (J. Roland Pennock \& John W. Chapman eds., 1983) (concluding that federal systems are in principle as capable of democratic representation as unitary, or nonfederal, systems).

477. The Federalist No. 46, supra note 340, at 294 (James Madison). The reliance on the people as the common denominator is also evident in The Federalist Nos. 28 and 51, see supra text accompanying note 380 (quoting texts), and has been noted by the Supreme Court. See, e.g., Gregory v. Ashcroft, 501 U.S. 452, 458-60 (1991).

478. Samuel Beer appears to take the view that Madison's allegiance to the people and to divided government were not only functionally consistent, but entirely interdependent — that is, that under the federal scheme the "outcome 'in every case' . . will 'depend on the sentiments and sanction'" of the constituents common to the states and the national government. Samuel H. Beer, To Make a Nation: The Rediscovery of American Federalism 298 (1993) (quoting Madison, but adding emphasis); id. at 295-301. If that is the argument, it seems patently wrong, even were it a correct interpretation of Madison, since the residents of one state might universally favor the state's policy goal but still lose to the national constituency favoring another policy goal. 
that international institutions may afford is decidedly inferior, if not intolerable. ${ }^{479}$

There are also good reasons, however, to regard the democracy argument against international delegation as less than decisive. Accountability for international delegations will differ materially from that for ordinary legislative exercises because exclusive and immediate control is compromised by the need to share authority with other nations. This does not necessarily mean, however, that decisions to delegate authority to international institutions are completely lacking in accountability. Congress may, after all, be held responsible for authority it has distributed even in excess of its continuing power over the agent; in consequence, it is not inconsistent to imagine the national government giving up power-i.e., putting final authority in the hands of others-without rendering it unaccountable for the original decision to set up the irrevocable power. The measured view, I believe, is that delegations to international institutions are not the democratic equivalent of ordinary legislation or even international agreements, but nor is it as though the international institutions in question have been vested with authority by a monarch. National democratic processes are, in an important regard, tied to the decisions made by international delegates, even if the strength of that connection leaves something to be desired.

Moreover, putting aside the prospects for democratic governance in international matters, ${ }^{480}$ the adverse impact on democratic values is ameliorated by the character of the decisions entrusted to international institutions. The expectations of exclusive electoral accountability are upended if we presume that the problems involved indeed affect others outside the United States. ${ }^{481}$ As Susan Marks observed, replying to the

479. One might also invoke, as is sometimes done, the Founders' aversion toward foreign entanglements. See, e.g., Ryan A. Candee, Book Annotation, 33 N.Y.U. J. Int'l L. \& Pol. 893, 893 (2001) (reviewing Delegating State Powers: The Effect of Treaty Regimes on Democracy and Sovereignty, supra note 283) (citing view held by some scholars that the constitutional structure disfavors such entanglements). The policy against foreign entanglements, originating in Washington's second term and encapsulated in his farewell address, emphasized that choosing sides in European affairs might expose the United States to reprisals. Samuel Flagg Bemis, Washington's Farewell Address: A Foreign Policy of Independence, 39 Am. Hist. Rev. 250, 262-64 (1934); George Washington, Farewell Address (Sept. 19, 1796), available at http://gwpapers.virginia.edu/farewell/transcript. html (last visited Aug. 31, 2004) (on file with the Columbia Law Review).

Involvement in international institutions, however, not only seems distinct from these "foreign" entanglements, but may even be regarded as consistent with that concerninsofar as the institutions adopt less partisan stances, enforce norms like nondiscrimination, and temper inconsistent unilateral and multilateral conduct. But see, e.g., U.N. Charter arts. 52-54 (establishing separate principles respecting use of force under regional arrangements); John H. Jackson, The World Trading System 165-67, 169-73 (2d ed. 1997) (describing awkward accommodation of bilateral and regional trading arrangements under the WTO).

480. See supra text accompanying notes 303-314.

481. Golove, supra note 15 , at 1700 n.8. 
claimed virtues of international lawmaking and enforcement by national leaders "who are accountable to the people,"

[D] emocratic legitimacy depends on accountability to those affected by such activities. In this context, those affected will necessarily include citizens of other countries, among them countries very probably not represented in the relevant [transgovernmental] network. ... When options in one country are shaped ... by decisions in other countries, national democracy-no matter how widespread and how deep-rooted-cannot suffice. ${ }^{482}$

The point, to be clear, is not that national democracies are being obviated, or that any international community exists that should supplant their decisions ${ }^{483}$ _ or even, for that matter, that incremental harm to national democratic values should be overlooked. The more limited argument, instead, is that while delegating legislative authority to international institutions may result in less democratic decisionmaking than would decisions about domestic matters by national (or state) institutions, decisions about international matters are a different kettle of fish. The international context matters, in other words, not only in evaluating the salience of the nondelegation principle, and the potential for harm to its underlying values, but also in alleviating what might otherwise be debilitating objections.

\section{B. Qualifications}

The foregoing discussion reemphasizes that not all international delegations are created equal. Among other things, the complexity of the international mechanism involved, its transparency, the nature of the interests affected, and its scope of authority will bear upon the risks of interest group monitoring, citizen monitoring, and capture ${ }^{484}$-all of which suggest the hazard of any generalized constitutional proscription.

482. Susan Marks, Democracy and International Governance, in The Legitimacy of International Organizations, supra note 61, at 47, 58; accord David Held, The Transformation of Political Community: Rethinking Democracy in the Context of Globalization, in Democracy's Edges, supra note 298, at 84, 103-06 [hereinafter Held, Transformation] (arguing that decisionmaking centers beyond national territories are appropriate when those significantly affected constitute a transnational grouping).

483. Professor Held, while decidedly optimistic about the potential for cosmopolitanism, is explicit about this. See Held, Transformation, supra note 482, at 103.

484. See John O. McGinnis, The Political Economy of Global Multilateralism, 1 Chi. J. Int'l L. 381, 385 (2000) (arguing that international institutions with plenary authority to sustain multilateral agreements are subject to special-interest group capture, as these institutions are distant from affected polities); McGinnis \& Movsesian, World Trade Constitution, supra note 284, at 515 (arguing that WTO would give leverage to protectionist special-interest groups if empowered to substantively regulate); Stephan, supra note 12, at 699-701 (suggesting that special-interest groups can lobby international lawmakers at lower cost, though with higher monitoring costs for the public, than they can domestic lawmakers). 
Even so, the federalism rationale sketched above supports several intuitions about appropriate limits to international delegations.

1. Monopolizing Delegations. - International organizations scholarship has chronicled two related phenomena: the proliferation of international organizations, on the one hand, and the growing competences of previously specialized organizations, on the other. The introduction of new, postcolonial nations into international affairs, together with the expanded scope of problems deemed amenable to international solution, has led to a slow but steady growth in the number of international organizations. ${ }^{485}$ While the number of "traditional" international organizations remained constant or dropped, the aggregate number of international organizations-including, for example, those created under the aegis of the UN, without a separate undertaking by its members-increased significantly. ${ }^{486}$ The spread of international organizations, and in particular their self-replication, diminishes the influence of traditionally powerful nations, ${ }^{487}$ and so may concern those occupied with the loss of U.S. sovereignty. ${ }^{488}$

A second, parallel trend has been toward the internal proliferation of functions, resulting in the development of conglomerate organizations. The phenomenon of "mission creep" is as common to international organizations as it is to other bureaucracies. ${ }^{489}$ Perhaps the most significant example is the WTO, which has seen its mandate expand with each successive round of negotiations. ${ }^{490}$ The WTO's principals seem to follow

485. See Jan Klabbers, The Changing Image of International Organizations, in The Legitimacy of International Organizations, supra note 61, at 221, 223 (citing "birth and death" statistics for agencies within the UN, and claiming that they may be generalized to bureaucratic growth outside the UN as well); Stein, supra note 12, at $489 \&$ n.2 (stating that most intergovernmental organizations created between 1982 and 1992 were founded by other intergovernmental organizations rather than by governments).

486. David Held, Democracy and The Global Order: From the Modern State to Cosmopolitan Governance 108 (1995); Cheryl Shanks et al., Inertia and Change in the Constellation of International Governmental Organizations, 1981-1992, 50 Int'l Org. 593, 598-600 (1996). For an updating of this analysis, and summary of causal explanations, see Niels Blokker, Proliferation of International Organizations: An Exploratory Introduction, in Proliferation of International Organizations: Legal Issues 1, 2-14 (Niels M. Blokker \& Henry G. Schermers eds., 2001) [hereinafter Proliferation].

487. See Shanks et al., supra note 486, at 600 (noting that powerful member states exert less influence over "emanations" from international organizations than in traditional methods of international lawmaking).

488. See, e.g., Abram Chayes \& Antonia Handler Chayes, The New Sovereignty: Compliance with International Regulatory Agreements 282-83 (1995) (describing resistance by developed nations to new, specialized agencies, which are perceived to regard developing nations as their principal clients).

489. See, e.g., Jessica Einhorn, The World Bank's Mission Creep, Foreign Aff., Sept./ Oct. 2001, at 22 (arguing that World Bank's mission has grown unmanageably complex as it has assumed challenges beyond its operational capabilities).

490. For a summary of insights into the causes and limits, see José E. Alvarez, The WTO as Linkage Machine, 96 Am. J. Int'l L. 146 (2002) [hereinafter Alvarez, The WTO as Linkage Machine]. 
what John Jackson termed the "bicycle theory" - "unless there is forward movement, the bicycle will fall over" 491 - and the WTO is under continual pressure to expand its mandate further to "non-trade" issues. ${ }^{492}$ This is not, needless to say, free of controversy; academics debate the wisdom of linkage, and widespread objections to expanding the WTO's mandate destroyed negotiations in Seattle and threatened to derail the WTO entirely. ${ }^{493}$

Defining these rival phenomena is hard-for example, developing new departments within an organization may be regarded as proliferation or conglomeracy ${ }^{494}$-as is generalizing about the merits of one or the other. As a general proposition, though, the diffusion defense of international delegations favors proliferation and disfavors conglomeracy, to the extent they are alternatives. Adding more international organizations maps roughly onto the preference of federalism for diversifying governance. ${ }^{495}$ Indeed, to the extent that organizations multiply without establishing any hierarchy among them, ${ }^{496}$ they more closely approximate the benefits of decentralization without the impediment of adding "trumps." 497 The downsides, of course, are coordination problems and

491. John H. Jackson, The World Trade Organization: Constitution and Jurisprudence 24 (1998).

492. See, e.g., José E. Alvarez, Foreword to Symposium: The Boundaries of the WTO, 96 Am. J. Int'l L. 1, 3 (2002) ("Pressures to link will continue to arise both from business interests eager to expand economic liberalization to new sectors such as investment and from prominent members of 'international civil society.'”).

493. See generally Symposium, The Boundaries of the WTO, 96 Am. J. Int'l L. 1 (2002) (addressing reasons that WTO members may want to link WTO to issues ostensibly unrelated to trade).

494. For one of many discussions of whether the UN should be regarded as a coherent organization, and whether coordination within it is feasible, see Nigel D. White, The World Court, the WHO, and the UN System, in Proliferation, supra note 486, at 85, 85-109.

495. It is also roughly consistent with calls for deliberative, fragmented governance. See, e.g., Perez, supra note 55, at 47 (extolling "fragmented view of the political experience" that "fits nicely with the decentralized nature of contemporary global law, which knows no 'universal center'"). See generally Marco Verweij \& Timothy E. Josling, Special Issue: Deliberately Democratizing Multilateral Organization, 16 Governance 1 (2003).

496. This is indeed the case as a general matter. International agreements are not supposed to be construed or administered in such a way as to cause conflict with other international obligations. But assuming a potential conflict, there are very few supremacy principles governing relations among international organizations once one goes beyond the UN Charter. U.N. Charter art. 103 (providing that "[i]n the event of a conflict between the obligations of the Members of the United Nations under the present Charter and their obligations under any other international agreement, their obligations under the present Charter shall prevail"). The trading system, for example, depends upon conflictreducing norms like the most favored nation principle, but has not been so successful at establishing a clear priority among multilateral, regional, and bilateral instruments. See supra note 479 .

497. See generally Gillette, supra note 383 (examining effects of decentralized "trumps" over centralized government authority). 
the risk of imposing conflicting obligations on member nations-though even that arguably tempers the bite of any international law emanating from the relevant institutions, and so enhances national and subnational discretion to choose among the relevant obligations. ${ }^{498}$

Conglomeracy, on the other hand, poses more tangible concerns. With respect to the U.S. system, Professors Rubin and Feeley expressed skepticism that "the aggregation of federal power across a broad range of governmental areas represents a dangerous concentration of power, even if its effect, in individual areas, is to disperse power among multiple authorities." ${ }^{99}$ But adding breadth to international institutions may be too much of a good thing. Sunken investments in a particular institution, linked benefits, and path dependence generally make it more difficult for a nation to exit an expanding institution than to decline to join a new one. ${ }^{500}$ This is valuable, for reasons already stated, insofar as it makes the commitment to international institutions more closely resemble a constitutional commitment to diffusion. ${ }^{501}$ It is counterproductive, on the other hand, to the extent that it accentuates the democracy deficit in the present governance of international institutions, ${ }^{502}$ or eclipses the ability to make constitutional changes that might reconcile the interests of supranational and subnational governments. ${ }^{503}$

498. See Blokker, supra note 486 , at $14-16$ (noting coordination issue and view of commentators that proliferation might imperil authority of existing principles and generation of new ones). At the extreme, though, the only result is chaos. See Chayes \& Chayes, supra note 488, at 283 (citing estimate that 180 different environmental bodies demanded active involvement by Swedish government).

499. Rubin \& Feeley, supra note 24, at 934.

500. See, e.g., Alvarez, The WTO as a Linkage Machine, supra note 490, at 148 ("The WTO encouraged path dependencies through sunk costs, learning and coordination effects, and adaptive expectations."); Martin \& Simmons, supra note 284, at 459 (suggesting that "states are least likely to be willing to withdraw from an institution in the face of unanticipated consequences when they are dealing with issues that exhibit increasing returns to scale, which, in turn, create conditions of path dependence"); see also text accompanying notes 184-185 (noting gulf between theoretical and practical ease of withdrawing from the WTO).

501. This may be a partial explanation for why national governments tend to resist conglomeracy. See Henry G. Schermers, Final Remarks, in Proliferation, supra note 486, at 549, 549 ("One large, strong hierarchically structured organization might be more effective but, apparently, governments do not want that kind of threat to their sovereign powers.").

502. See, e.g., id. at 551 (expressing concern that "[o]ne large international organization, hierarchically supervising and co-ordinating all activities of other organizations may become so powerful that a sophisticated system of democratic legitimacy would be required").

503. The experience in the European Union to date has been relatively heartening. Many have been concerned that the EU, like other supranational institutions, might effectively transfer control over domestic affairs to institutions more susceptible of national control. See, e.g., Michael Keating, The New Regionalism in Western Europe: Territorial Restructuring and Political Change (1998); Naomi Roht-Arraiza, The Committee on the Regions and the Role of Regional Governments in the European Union, 20 Hastings Int'l \& Comp. L. Rev. 413, 421-23 (1997); see also Vivien A. Schmidt, European "Federalism" 
If we truly value the federalist strengths of international delegations, regional institutions may be the most appealing. First, because their management and legal principles more likely correlate with regional rather than universal norms, they will be more proximate to any regional community that may exist. Second, insofar as federalism is concerned with providing safeguards against the national government, regional institutions better permit exit by those governed. For example, a corporation dissatisfied with residing in the United States, Canada, or Mexico-or, for that matter, with residing in the European Union-has some alternatives, though its trade in those regions will undoubtedly continue to be fettered. ${ }^{504}$

To be sure, regionalism is not an unmitigated good. Redistributive policies, for example, may be available only under conditions constraining flight. ${ }^{505}$ Proximity may also be a two-edged sword: Lower levels in multilevel governance-the states in the U.S. federal system, the cities in the state system, and perhaps regions in the international system-are sometimes said to act more repressively toward still more local levels. ${ }^{506}$ Finally, the long-term repercussions are unknown. The conventional criticism is that regional institutions interfere with developing multilateral efforts that are better suited to the task, ${ }^{507}$ while others contend that regionalism is only a way station on the path to more global coordi-

and its Encroachments on National Institutions, 29 Publius 19 (1999). Others have suggested that such institutions instead reinvigorate European federalism, and diminish the stranglehold of national governments. See Udo Bullmann, The Politics of the Third Level, in The Regional Dimension of the European Union: Towards a Third Level in Europe? 3 (Charlie Jeffery ed., 1997); Jackie Jones, The Committee of the Regions, Subsidiarity and a Warning, 22 Eur. L. Rev. 312, 314 (1997); John Newhouse, Europe's Rising Regionalism, Foreign Aff., Jan./Feb. 1997, at 67. The development of the principle of subsidiarity under the Maastricht and Amsterdam treaties and the parallel growth in the authority of the Committee of the Regions, as amplified in the draft constitution presently under discussion, suggest mounting evidence for the latter view. See Conference of the Representatives of the Governments of the Member States, Treaty Establishing a Constitution for Europe, arts. I-11, I-32, III-386-III-388, CIG 87/04 (Aug. 6, 2004), available at http://ue.eu.int/igcpdf/en/04/cg00/cg00087.en04.pdf (on file with the Columbia Law Review) (describing principle of subsidiary and basic functioning of Committee of the Regions); cf. id. art. I-60 (providing, for the first time, explicit authorization for voluntary withdrawal by member states from the European Union).

504. See Kenneth Norrie, Is Federalism the Future? An Economic Perspective, in Rethinking Federalism, supra note 327, at 135, 146-50.

505. See Larry Kramer, Understanding Federalism, 47 Vand. L. Rev. 1485, 1548-51 (1994) (discussing Paul E. Peterson, City Limits 66-92 (1981)).

506. See supra note 395 and accompanying text (explaining that federalism may hinder local power).

507. See Bernard K. Gordon, A High-Risk Trade Policy, Foreign Aff., July/Aug. 2003, at 105; see also John Odell \& Barry Eichengreen, The United States, the ITO, and the WTO: Exit Options, Agent Slack, and Presidential Leadership, in The WTO as an International Organization 181, 206 (Anne O. Krueger ed., 1998) (concluding that the United States will have limited alternatives to the WTO for the near future, and that "[a]s the web of U.S. trade relations spreads increasingly wide, regionalism will probably become progressively less attractive as an alternative to multilateral negotiation”). 
nation. ${ }^{508}$ If the latter judgment is accurate, such that any disadvantages to regionalism tend to be transient, it may provide an intermediate course for reconciling localism, internationalism, and U.S. federalism.

2. Reverse Delegations. - Besides the U.S. Constitution, the constitutions of international institutions themselves may indicate whether nondelegation and federalism values are in tension. One important question concerns whether, and how, the principle of delegata potestas non potest delegari ("a delegated authority cannot be again delegated") is heeded. While the authority of international organizations to delegate power to subsidiary organs is widely presumed ${ }^{509}$ the propriety of assuming the power to delegate outside the organization may be more controversial. More particularly, what may be called reverse delegations-in which institutions vested with delegated authority pass that authority back to their principals-are, in one view, presumptively acceptable if done so as to respect sovereign equality and territorial integrity. ${ }^{510}$ Others would require more specific authorization, and various other safeguards extrapolated from the delegata non potest maxim. ${ }^{511}$

The fact of the matter, in any case, is that some organizations do engage in reverse delegation, and the most significant example exceeds any territorial limit. The Security Council has repeatedly delegated its authority over international peace and security to member states and regional organizations. ${ }^{512}$ Assuming that this practice is (or has become) consistent with the UN Charter and general principles of international law, it remains suspect as a matter of delegation values: The specter that an international institution may be delegated authority, then redelegate that authority in a manner that converts a national principal into the institution's agent, raises serious accountability issues, particularly given the potential limitations on curtailing the delegation under international law. 513

508. G.C.A. Junne, International Organizations in a Period of Globalization: New (Problems of) Legitimacy, in The Legitimacy of International Organizations, supra note 61, at 189, 214.

509. Danesh Sarooshi, The United Nations and the Development of Collective Security: The Delegation by the U.N. Security Council of its Chapter VII Powers 16-18, 119 (1999); Schermers \& Blokker, supra note 42, § 224.

510. Schermers \& Blokker, supra note 42, § 229 ("As a rule, international organizations may be considered to be entitled to delegate tasks to all member states, each being obliged to perform them within their own territory."); see also id. ("Delegation of tasks of the organization to one or more specific member states will generally not be permitted unless there are particular reasons, such as geographic position, which justify such delegation.").

511. See Sarooshi, supra note 509, at 18-49 (laying out general limitations on Security Council's powers of delegation); id. at 142-66 (laying out specific limitations on Security Council's delegations of power to member states).

512. Id. at 167-246 (citing, among other examples, conflicts in North Korea, Iraq, Somalia, and Bosnia).

513. See supra note 181 (discussing reverse veto); see also Effect of Awards of Compensation Made by the U.N. Administrative Tribunal, 1954 I.C.J. 47, 56-63 (July 13) 
The Security Council's practices may be unavoidable, absent any standing international military, but similar problems may be identified in other settings. For example, because the Clean Diamond Trade Act's dependence on the WTO or the Security Council was perceived to present an unconstitutional international delegation, the President interpreted the Act as permitting the plenary evaluation of relevant international measures. ${ }^{514}$ The obvious difficulty with that solution, though, is that it converts a relatively esoteric assimilation problem into a garden-variety nondelegation offense. In Clinton v. City of New York, the Supreme Court distinguished between prior cases, in which "Congress itself made the decision to suspend or repeal the particular provisions at issue upon the occurrence of particular events subsequent to enactment, [leaving] only the determination of whether such events occurred up to the President," and the Line Item Veto Act, which would unconstitutionally permit the President to cancel legislation based on an independent exercise of policy discretion. ${ }^{515}$ That reasoning appears to apply squarely to presidential assertions of standardless discretion to determine the domestic status of international acts.

The problem of reverse delegations also has immediate relevance to the compatibility of delegations with federalism. Federalism controversies involving NAFTA and the Uruguay Round were resolved by providing that neither the international agreement, the implementing legislation, nor even the decisions applying the agreement would automatically preempt state laws. That authority, instead, would rest initially in the hands of the federal government, which could elect whether to initiate litigation to effectively overrule the state law. ${ }^{516}$

This is generally considered to have been a triumph for cooperative federalism, ${ }^{517}$ and is certainly critical in evaluating whether international

(upholding authority of General Assembly to constrain itself to be bound by the decisions of its delegate exercising a delegated power, such as the power to render judgments binding on the Assembly).

514. See supra note 100 (citing Statement on Signing the Clean Diamond Trade Act, 39 Weekly Comp. Pres. Doc. 491 (Apr. 25, 2003) ("If section 15 imposed a mandatory duty on the President to certify to the Congress whether either of the two specified events has occurred and whether either remains in effect, a serious question would exist as to whether section 15 unconstitutionally delegated legislative power to international bodies.")).

515. 524 U.S. 417, 445 (1998) (distinguishing Field v. Clark, 143 U.S. 649 (1892)).

516. E.g., Uruguay Round Agreements Act of 1994, Pub. L. No. 103-465, § 102, 108 Stat. 4809, 4815-19 (2003) (codified at 19 U.S.C. $\$ 3512$ (1994)) (barring anyone other than the United States, including private parties, from challenging U.S. or state action or inaction based on its consistency with the statute, as well as providing a process by which the United States is to consult with the states and provide notice to Congress before taking legal action against a state or local government for noncompliance with the statute); see Sager, One Voice, supra note 362, at 104-11 (quoting statements of administrative action and legislative history).

517. See, e.g., Tangeman, supra note 16, at 258 ("NAFTA's implementation of a cooperative mechanism for state participation in federal decisions concerning international trade activities should alleviate the fears that NAFTA violates state sovereignty and restore that balance."). 
delegations interfere with local autonomy and accountability. As a matter of delegation, though, it treads a fine line. The executive branch ordinarily possesses the authority to refuse enforcement of the law in otherwise meritorious cases when, in its judgment, doing so would have serious constitutional consequences. ${ }^{518}$ It is less common, however, for a statutory scheme to contemplate what amounts to the executive veto, after the fact, of the legal defense to a damages judgment-one running against the United States. If this amounts to a redelegation to the executive branch, it may at least be said that the benefits of diffusion are not being captured, and the accountability problems associated with delegations loom relatively large. ${ }^{519}$

\section{ConcLusion}

One of the greater ironies of globalization is how it has revived interest in local governance. The conventional wisdom is that the United States abandoned federalism in our foreign affairs "even before it began to be a wasting force in U.S. life generally." ${ }^{20}$ One might fairly suppose that "Our Federalism" 521 - an idea with dated and parochial connotations even within the United States-has still less current appeal internationally, and would either fade quietly or survive only as an idée fixe within certain American circles. ${ }^{522}$

Yet those designing and evaluating international institutions often allude to federalism as a leading template. ${ }^{523}$ Institutions are considered

518. See supra note 200 (noting that U.S. President may refuse to enforce statutes that are considered unconstitutional).

519. Representative Kucinich made a similar argument in proposing an amendment to the Departments of Commerce, Justice, and State, and Judiciary, and Related Agencies Appropriations Act of 1999, 144 Cong. Rec. 18981, 18981 (1998) ("Congress gave too much power to the administration by permitting it to preempt the laws of local and State governments on the grounds that they are inconsistent with international trade and investment agreements. That is the function of Congress.").

520. Henkin, Foreign Affairs, supra note 15, at 149; see supra note 366 and accompanying text (noting obsolescence of dual federalism).

521. E.g., Younger v. Harris, 401 U.S. 37, 44 (1971).

522. Michael Greve summarized the skeptical perspective, without entirely endorsing it, in this way:

Federalism is about borders, and borders are disappearing in an age of enormous economic, social, and geographic mobility. Trillions of dollars jump political boundaries at the push of a button. . . . Millions of Americans spend half their waking hours in cyberspace, a global forum where the prerogatives of the Mississippi state government rarely become an issue. In short, federalism looks fusty - the province of latent racists, pedantic social scientists, and opportunistic political campaign consultants who understand the power behind the rebel flag. Michael Greve, AEI Federalist Outlook, The AEI Federalism Project (July 2000), at http:// www.federalismproject.org/outlook (on file with the Columbia Law Review).

523. Daniel Elazar, for example, maintained that federalism was replacing liberal internationalism. See Daniel J. Elazar, Constitutionalizing Globalization: The Post Modern Revival of Confederal Arrangements 15 (1998); Daniel J. Elazar, The State System + Globalization (Economic Plus Human Rights) $=$ Federalism (State Federations Plus 
well-tailored when they address collective action problems and externalities of the type giving rise to the U.S. national government, while affording national autonomy as much respect as that owed U.S. states under the domestic constitution. ${ }^{524}$ The reason, in principle, is not merely that international centralization is politically unattainable, ${ }^{525}$ but also that jurisdictional competition under federalism will yield appropriate regulation. ${ }^{26}$ Some perceive, indeed, that globalization will increasingly favor a division of authority between international and subnational governments, with the real losers being national sovereigns. ${ }^{527}$

Regional Confederations), 40 S. Tex. L. Rev. 555, 556-57 (1999); Raustiala, Rethinking, supra note 12, at 845 (explaining that " $[\mathrm{b}]$ oth federalism and the creation of international institutions suggest that power is best allocated across several levels of governance, rather than aggregated at a single level," while noting dissimilarities); see also Leslie Friedman Goldstein, Constituting Federal Sovereignty: The European Union in Comparative Context 4-5 (2001) (citing international organizations as progressive development from sovereignty splintered by federal systems); cf. Immanuel Kant, Perpetual Peace: A Philosophical Sketch, reprinted in Kant's Political Writings 93, 102 (Hans Reiss ed., 1970) (urging that "[t]he Right of Nations Shall be based on a Federation of Free States"). Perhaps the most important example is the European Union, which many perceive to be making purposeful strides toward federalism (while zealously avoiding any official embrace of that aim). Gerard Baker, Against United Europe, Wkly. Standard, Sept. 22, 2003, at 23; Gerard Baker, How the EU Could Bulk Up, Bus. Wk., June 30, 2003, at 64. But cf. Perez, supra note 55, at 42 (casting skeptical eye on "radical vision" of global federalism, and holding up European Union as an example of its ills).

524. See, e.g., McGinnis \& Movsesian, World Trade Constitution, supra note 284, at $542-44$.

525. International federalism is invoked most frequently in disciplines where the notions of centralizing authority and surrendering national autonomy are plainly infeasible-such as antitrust, e.g., Eleanor M. Fox, Antitrust and Regulatory Federalism: Races Up, Down, and Sideways, 75 N.Y.U. L. Rev. 1781 (2000), and environmental law, e.g., Daniel A. Farber, Environmental Federalism in a Global Economy, 83 Va. L. Rev. 1283 (1997) — as is generally the case in international matters. Alvin K. Klevorick, The Race to the Bottom in a Federal System: Lessons from the World of Trade Policy, 14 Yale L. \& Pol'y Rev. \& Yale J. on Reg. 177 (1996); see, e.g., Richard L. Revesz, Federalism and Environmental Regulation: Lessons for the European Union and the International Community, 83 Va. L. Rev. 1331, 1341 (1997) (addressing centralization in international environmental regulation).

526. See Daniel C. Esty, The World Trade Organization's Legitimacy Crisis, 1 World Trade Rev. 7, 18 (2002) (citing possibility for designing vertical competition between international and national governments for "optimal public decisionmaking"). The potential for such competition, and whether there are offsetting risks, clearly depends upon the issue area. Cf. William W. Bratton \& Joseph A. McCahery, The New Economics of Jurisdictional Competition: Devolutionary Federalism in a Second-Best World, 86 Geo. L.J. 201 (1997) (arguing for context-sensitive evaluation of prospects for competition, and suggesting that burden lies with those invoking competition's benefits).

527. See, e.g., Richard Simeon \& Katherine Swinton, Introduction: Rethinking Federalism in a Changing World, in Rethinking Federalism, supra note 327, at 3, 9 ("[G]lobalization is a greater threat to central governments than to state and provincial governments, and, hence, that authority in the present era is being stretched like a concertina, with influence flowing both upwards to public and private supranational institutions and downwards to smaller units.”); Mark Tushnet, The Supreme Court, 1998 Term-Foreword: The New Constitutional Order and the Chastening of Constitutional Aspiration, 113 Harv. L. Rev. 29, 109 (1999) (noting that sovereignty appears to be flowing 
The increasing clamor to the effect that globalization and domestic federalism principles may be rivalrous, then, is somewhat ironic-if poetic justice, given the headaches that state governments posed for reaching, and abiding by, international agreements. ${ }^{528}$ But it also appears misconceived, or hasty at best. The delegation of authority to international institutions certainly challenges the traditional prerogatives of states and localities, as it does those of national governments, and the costs it exacts are far less self-imposed. Given the loss of authority that accompanied U.S. political and economic integration, it is unsurprising that states would feel threatened, especially given the lack of any international ana$\log$ to the U.S. Senate.

But if we look beyond the adverse effects international institutions may have on the existing agents of U.S. federalism, the prospects are less bleak. Taking international delegations seriously reveals a constitutional character that serves, however inadvertently, many of the same ends as have the U.S. states. On this view, delegations of lawmaking authority to international institutions may promote the values underlying domestic federalism, vindicating rather than cannibalizing their normative warrant-and doing so when the legitimacy of those institutions is at a critical juncture. ${ }^{529}$

This perspective also speaks to a puzzle of continuing significance to legal scholarship: Why are some norms, like nondelegation and federalism, underenforced? The conventional story involves their amenability to judicial enforcement; the conventional reaction to the resulting gaps between constitutional doctrine and practice is to redress them, either by reviving enforcement or interring the doctrine. As this Article suggests, it may be more appropriate to examine the values underenforced doctrines seek to promote. Sometimes those values have reached their natural limits, or they encounter tensions endogenous to the doctrine itself-as when it is recognized that Congress must delegate in order to ensure effective administration, or that a national government must intervene in otherwise local domains in order to provide a collective good.

In the instant case, however, discovering legitimate bases for worrying about international delegations also provides a ground for resolving an extrinsic constitutional objection-federalism-and reveals a potential reason actually to embrace those delegations. Here, at least, under-

\footnotetext{
"upward, to supranational government institutions" and "downward, to subnational governments").

528. I addressed each of these headaches in previous work. Swaine, Treaty Power, supra note 224, passim (considering whether constitutional federalism obstructs exercise of national treaty power); Swaine, Negotiating Federalism, supra note 221, passim (addressing whether state foreign relations activities are precluded by national treaty power).

529. See, e.g., Esty, supra note 526, at 9-14 (describing erosion of rational, bureaucratic foundation for the WTO); id. at 19 (describing compelling need for enhancing public acceptance of WTO, and observing that "it is essential that 'space' be reserved for separate domestic political processes . . . just as the US Constitution reserves important elements of authority to the states").
} 
enforcement respects the tradeoffs among our constitutional commitments, and resists readings of the Constitution that mistake the part for the whole. ${ }^{530}$ International delegations may yet suffer constitutional infirmities, including on nondelegation and federalism grounds, but the prudent course is to carefully assess their costs and benefits, not to dismiss them-and to acknowledge that international institutions may advance not only international governance, but the constitutional vision of national governance as well.

530. Contrast, for example, Senator Helms's speech before the UN, in which he asserted an unavoidable link between delegated authority and the Constitution:

$[W]$ hen the United States joins a treaty organization, it holds no legal authority over us. We abide by our treaty obligations because they are the domestic law of our land, and because our elected leaders have judged that the agreement serves our national interest. But no treaty or law can ever supercede the one document that all Americans hold sacred: The U.S. Constitution.

U.S. Sen. Jesse Helms, Chairman, Senate Comm. on Foreign Relations, Address Before the UN Security Council (Jan. 20, 2000), in 1 Sean D. Murphy, United States Practice in International Law 5 (2002). 